
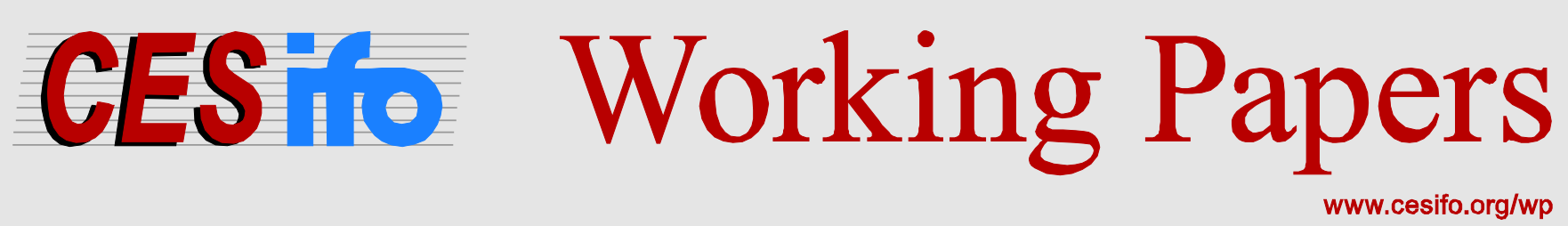

\title{
Après Nous le Déluge? Direct Democracy and Intergenerational Conflicts in Ageing Societies
}

\author{
Gabriel M. Ahlfeldt \\ Wolfgang Maennig \\ Malte Steenbeck
}

CESIFO WORKING PAPER NO. 5779

CATEgory 2: Public CHOICE

FEBRUARY 2016

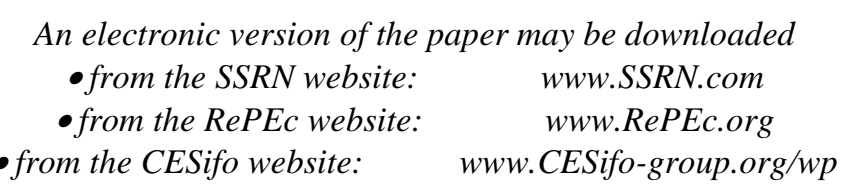

ISSN 2364-1428 


\title{
Après Nous le Déluge? Direct Democracy and Intergenerational Conflicts in Ageing Societies
}

\begin{abstract}
To assess the likely effects of population ageing on the outcomes of direct democracy, we analyze the effect of age on voting decisions in public referenda. To this end, we provide the first quantitative review of the literature and a case study of the Stuttgart 21 referendum on one of the largest infrastructure projects in Germany. The evi-dence suggests that intergenerational conflicts arising from population ageing will likely be limited to areas in which the net present value differs particularly strongly across generations, such as education and health spending, green energy, and major transport projects. In such instances, however, the effect can be quantitatively relevant, raising the question of whether, as population ageing progresses, decisions should be based on social cost-benefit analyses, instead of referenda.
\end{abstract}

JEL-Codes: D610, D620, H410, H710, L830, I180, R410, R580.

Keywords: ageing, direct democracy, intergenerational conflict, NIMBY, referendum, Stuttgart 21, transport, voting.

Gabriel M. Ahlfeldt

London School of Economics and Political Science (LSE)

Houghton Street

United Kingdom - London WC2A 2AE

g.ahlfeldt@lse.ac.uk

www.ahlfeldt.com

\author{
Wolfgang Maennig \\ University of Hamburg \\ Department of Economics \\ Chair for Economic Policy \\ Von-Melle-Park 5 \\ Germany - 20146 Hamburg \\ wolfgang.maennig@wiso.uni-hamburg.de
}

\author{
Malte Steenbeck \\ University of Hamburg \\ Department of Economics \\ Chair for Economic Policy \\ Von-Melle-Park 5 \\ Germany - 20146 Hamburg \\ malte.steenbeck@wiso.uni-hamburg.de
}

Version: January 2016

Alex Ram provided excellent research assistance. We would further like to thank the participants at seminars and conferences in Berlin and Hamburg for comments and suggestions. 


\section{Introduction}

The increasing life expectancy and reduced fertility imply that, by 2050, the number of older persons (aged 60 years or over), or the elderly, will increase from less than 850 million (2013) to more than two billion. Moreover, by 2047, the elderly will exceed children in number for the first time in history. In fact, the share of the elderly in the total world population will almost double to $21.1 \%$. The median age will increase by one third, from less than 30 (29.1) to almost 40 (39.1) years. In developing countries, the ageing of society will have progressed even further by 2050. In the US, the share of the elderly is projected to increase to $27 \%$, which is almost twice as high as that in 1980 (15.7\%). Further, in Germany, the same share will escalate to almost $40 \%$ and the median age will exceed 50 years. ${ }^{1}$

This unprecedented population ageing has both diverse and substantial economic implications. Just to name a few, population ageing puts pressure on social security systems (Breyer and Stolte, 2001; Demange and Laroque, 1999) and potentially affects returns of capital (Abel, 2001; Krueger and Ludwig, 2007; Poterba, 2001) as well as economic growth prospects (Acemoglu and Johnson, 2007; Holtz-Eakin et al., 2004). The implications for the political economy are potentially and similarly severe. It is, for various reasons, likely that the generational interests of the elderly differ from those of the younger generations. The typical example discussed in economics literature is a lower preference for government spending on public schools because the elderly usually do not have school-aged children (Brunner and Balsdon, 2004; Gradstein and Kaganovich, 2004; Poterba, 1998; Rubinfeld, 1977). However, because the elderly are usually no longer part of the working population, they also face a different trade-off when it comes to initiatives that would promote economic development at the expense of recreational value, and vice versa (Fischel, 1979). Moreover, at any given point in time, the lower life expectancy should imply that any project offering long-term benefits, but short-term disruptions during prolonged construction periods, should appear less attractive to the elderly than to other generations. For similar reasons, the elderly may be less sensitive to the long-term cost of non-renewable energy production and consumption (Thalmann, 2004).

If the elderly's preferences are determined by narrow self-interest, as described above, the expected ageing of the median voter implies a harder hurdle for public investments into education, infrastructure, and green energy, the benefits of which materialize in the long-run, thus, potentially creating an intergenerational conflict (Brunner and Balsdon, 2004; Holtz-Eakin et al., 2004; Ladd and Murray,

1 All figures are taken from the 2013 UN World Population Ageing report and the corresponding Profiles of Ageing 2013 interactive database (United Nations, 2013). 
2001). However, it is also theoretically possible that the elderly internalize benefits to future generations because they care about their children and grandchildren (Bernheim and Ray, 1987; Rapoport and Vidal, 2007), are guided by a sense of morale (Feigenbaum et al., 1988), ${ }^{2}$ or seek to maintain a tax base necessary to finance programs that support them (Richman and Stagner, 1986). Thus, whether intergenerational tensions exist is an empirical issue.

One instance where the elderly's attitudes toward public policies become apparent and immediately relevant is in direct democracy processes such as public referenda. ${ }^{3}$ Since 1978 , there has been a storm of ballot-box lawmaking in the US, in virtually every field of policymaking (Matsusaka, 2005). Over $70 \%$ of the US population lives in states or cities where direct democracy is an established option for political decision-making (Matsusaka, 2004). Moreover, direct democracy is spreading internationally. In many countries, it has become almost expected that first-order issues affecting national sovereignty be carried directly to the voters. Examples include various referenda on European Union monetary and market integration, the 2004 "peace referendum" in Taiwan to define relations with mainland China, or the 2014 referendum on Scottish independence from the UK.

To date, there is no systematic evidence regarding the nature of the elderly's attitudes expressed in public referenda. The existing empirical analyses of direct votes do not normally focus on age-related effects; where age is considered a determinant of the voting decision, it is typically viewed as a potentially confounding factor that is not central to the analysis. As a result, the evidence base is scattered across studies in separate, unconnected literature strands. A solid evidence base regarding the nature of elderly voting in public referenda, however, is critical to understanding the implication of population ageing for the outcomes of direct democracy. In particular, the question of how, in an ageing society, decisions on projects that offer a positive net present value, but benefits that materialize in the long run, is important to consider. For instance, can such decisions be delegated to voters, or should they be based on social cost-benefit analyses as recommended for "private value environments," in which the expected net benefits vary greatly across groups of voters (Osborne and Turner, 2010)?

2 Feigenbaum et al., (1988) argue that the respective history of thought dates back to Aristotle (1975).

3 In the US, a referendum differs from an initiative in that the former is a vote on a law that is already approved by the legislature, while the latter is a vote on a law proposed by ordinary citizens. Throughout this paper, we use the term referendum as referring to any election in which citizens have a direct vote on a law. 
To answer this question, we conduct the first quantitative survey on the evidence of age effects revealed in empirical analyses of public referenda. We also contribute the first empirical analysis of a public referendum, which focuses specifically on age as a choice determinant in a referendum of a major infrastructure project. Finally, we provide an exemplary illustration of the quantitative relevance of population ageing for direct democracy outcomes by combining our case-study estimates of the age effect with a population projection.

In our quantitative survey, we cover 82 referenda analyzed in 32 studies on a wide range of topics, including spending on public schools, political integration, infrastructure projects, energy, and the environment. For each analysis, we examine the direction and significance of the effect associated with an age-related variable, and categorize the implied attitude by the elderly as either individualistic (in generational self-interest), neutral, or collectivistic (in the interest of other generations), depending on the particular context. These terms are borrowed from psychology literature, which analyzes the extent to which individuals give priority to personal (individualistic) or group (collectivistic) goals (Oyserman et al., 2002; Triandis, 1995). We find significant age effects in the direction that we associate with generational self-interest in almost $50 \%$ of the referenda, while less than $10 \%$ reveal significant age effects in the opposite direction. The remaining studies reveal statistically insignificant age effects. This tendency is particularly evident in referenda on public school funding, health services, and energy-related questions; however, for a range of other categories of referenda, the tendency is less clear. For instance, in referenda on sports facilities or European integration, the elderly vote in line with other generations in the majority of cases analyzed.

The case study that we contribute to the extant literature is an analysis of the 2011 Stuttgart 21 referendum, in which voters were asked to either support or reject the development of a new central rail station in Stuttgart, Germany. 4 The new station, including all feeder lines, would be developed underground, freeing up the current track beds for urban redevelopment. For our purposes, the Stuttgart 21 referendum makes an interesting study case for a number of reasons. First, it is a large referendum, in the sense that 7.6 million eligible voters in the German state of Baden-Württemberg were called to the ballots to decide on a €6.5 (\$9) billion project. ${ }^{5}$ Second, a construction period of at

4 Wagschal (2013) analyzes the same referendum using more aggregated data.

5 Throughout the paper, we use a $\$$ /€ exchange rate of 1.392 , the mean rate in 2011 , which is the year of the Stuttgart 21 referendum. 
least 10 years was expected, during which there would be significant disruptions in urban and regional transit. Therefore, the expected net present value of the project should decline in an individual's age if benefits to other generations are ignored. Third, population ageing is progressing particularly rapidly in Germany, making it an interesting country in which to quantify the possible effects on referendum outcomes.

The project was approved by a relatively clear 58.9\% majority, and the turnout was unusually high at $48.3 \%$. Controlling for other factors, we find that an increase in the average age of the adult population within a municipality by one year was associated with a $0.71-1.17$ percentage point increase in the share of votes opposing the project. Using instruments to remove shocks that simultaneously determine the age structure of and preferences toward Stuttgart 21 tends to increase the estimated age effect. A back-of-the-envelope calculation in the spirit of Poterba (1998) suggests that despite the clear majority vote in 2011, population ageing could cause a similar referendum to fail within a couple of decades.

Taken together, the evidence collected suggests that intergenerational conflicts arising from population ageing are likely to be limited to topics where the net present value differs particularly strongly across generations. Examples include spending on public schools or infrastructure projects that involve major costs in the short term and benefits only in the long run. In such specific instances, however, decisions may be better based on social cost-benefit analyses as population ageing progresses.

Our results contribute to a number of strands in the political economy, public economics, and urban economics literature. We directly connect to literature that has investigated intergenerational conflicts against the background of population ageing (Brunner and Balsdon, 2004; Holtz-Eakin et al., 2004; Ladd and Murray, 2001; Poterba, 1998). Moreover, we relate to literature that has analyzed how interest groups, such as homeowners (Ahlfeldt and Maennig, 2015; Dehring et al., 2008; Fischel, 2001a) and those with the "not-in-my-backyard" viewpoint (NIMBYs) (Feinerman et al., 2004; Fischel, 2001b; Frey et al., 1996), seek to influence political outcomes. In general terms, we contribute to major strands in economics literature that are concerned with political opposition to projects with positive net present value (Fernandez and Rodrik, 1991; Kahneman et al., 1991), the nature of direct-democratic decision making (Deacon and Shapiro, 1975; Feld and Matsusaka, 2003; Matsusaka, 2004; Osborne and Turner, 2010), and the economics of accessibility and transportation (Ahlfeldt et al., 2015; Baum-Snow, 2007; Duranton and Turner, 2012). 
The remainder of the paper is structured as follows. Section 2 analyzes the relationship between voter age and incentives, by means of a quantitative literature survey. Section 3 presents our case study on Stuttgart 21. Finally, Section 4 discusses our conclusions.

\section{Quantitative survey}

There is a vivid debate on whether the elderly support or oppose the spending on public schools, with mixed results (e.g., Brunner and Balsdon, 2004; Harris et al., 2001; Ladd and Murray, 2001; Poterba, 1998; Rubinfeld, 1977). On other topics, however, the evidence is generally scarce and scattered across various studies in separate literature strands. To provide a synthesis of the state of knowledge, this section provides the first quantitative summary of evidence on age-specific voting patterns in public referenda.

\subsection{Literature review}

In collecting the evidence base for our quantitative literature review, we follow standard best-practice approaches of meta-analytic research, as reviewed by Stanley (2001). ${ }^{6}$ We include studies that empirically analyze the determinants of voting decisions in public referenda and include at least one age-related variable as a covariate. ${ }^{7}$ To maximize the evidence base, we consider analyses of grouped data, typically at the level of voting precincts, and post-referendum surveys that inquire about voters' decisions in actual referenda. Depending on the research design, the age-related variable can take various forms, such as the actual age of an interviewee, average age of the population living in a voting precinct, or respective share of an age group (e.g., 60 and older). Further, to prevent publication bias, we consider studies that were published as edited book chapters, in refereed journals, or in academic working paper series.

In searching for empirical analyses of public referenda, we pursue a three-step strategy. We begin with the standard practice of a keyword search in academic databases (EconLit, Web of Science, and Google Scholar) and specialist research institute working paper series (NBER, CEPR, CESIfo, and IZA). Because analyses of public referenda usually do not focus on age effects, searching for age-related terms (e.g., age, generation, and intergenerational conflict) did not prove useful. Instead, we used key terms, such as "voting analysis", "referendum analysis", "precinct analysis", "referendum + analysis",

6 Recent examples of meta-analyses in economics include studies by Eckel and Füllbrunn (2015), Melo (2013), and Nitsch (2005).

7 In one instance, the analysis was descriptive rather than econometric (Pelinka, 1983). 
"vote + infrastructure", and "referendum + empirical" to identify as broad as possible a base of empirical analyses of referenda. This search yielded 33 studies, which, upon a first inspection, satisfied the minimum standards of academic rigor and were suitable for our meta-analyses. Starting from the identified studies, we then conducted both an upstream and downstream analysis of citation trees, which increased the set of candidate studies to 53. In the third step, we asked colleagues working in related fields to recommend empirical analyses of referenda. This added a further 15 studies to the list, resulting in 68 potential studies. Because the existing referendum analyses typically do not focus on age as a primary determinant of voting decisions, we are more likely to miss some relevant evidence in this study than in a typical meta-analysis reviewing a self-contained literature strand. On the positive side, the same fact also makes it is less likely that there is publication bias in favor of statistical significance or a certain direction of the age effect.

After eliminating duplications (working papers and academic publications), studies that were of subordinated relevance for the purposes of this review (e.g., theoretical work), or generally suitable analyses without age-related covariates, we were left with a pool of 32 studies, which we summarize in Table 1. Because several studies analyze more than one referendum, the total number of referenda amounts to 82. Most referendum topics relate to school spending, environmental legislation, energy policies, European integration, transport, and, perhaps somewhat surprisingly, sports facilities. Reflecting the variety of topics, popular publication outlets are journals related to environmental, political, public, and urban economics. More than three quarters of the studies analyze grouped data at the voting precinct level, while the remaining studies collected individual data in post-referendum surveys. Over time, the analysis of grouped data has become more popular, likely reflecting the increasing availability of data for relatively small spatial units. All studies analyze referenda held either in the US or EU (and associated countries), with the US accounting for the larger share (20 vs. 12 studies). We provide further detail on the referenda in those studies, as well as the information that we extract, in Table A1 of Appendix I. 
Tab. 1. List of studies

\begin{tabular}{|c|c|c|c|c|c|c|c|}
\hline$\#$ & Year & Author & Publication & $\mathrm{N}$ & Analysis & Topic & Country \\
\hline 1 & 1977 & Rubinfeld & REStat $^{\mathrm{a}}$ & 2 & Survey & School spending & US \\
\hline 2 & 1979 & Fischel & JEEM $^{\mathrm{b}}$ & 1 & Survey & New plant & US \\
\hline 3 & 1982 & Noam & Public choice & 12 & Referendum & Various & Switzerland \\
\hline 4 & 1983 & Ladd \& Wilson & JPAM $^{\mathrm{c}}$ & 1 & Survey & School spending & US \\
\hline 5 & 1983 & Pelinka & Electoral Studies & 1 & Survey & Nuclear energy & Austria \\
\hline 6 & 1988 & Feigenbaum et al. & Public Choice & 1 & Referendum & Nuclear energy & US \\
\hline 7 & 1992 & Button & $S_{S Q}^{d}$ & 6 & Referendum & School spending & US \\
\hline 8 & 1997 & Agostini et al. & Book chapter & 2 & Referendum & Sports facility & US \\
\hline 9 & 2000 & Schulze \& Ursprung & Public Choice & 1 & Referendum & Culture & Switzerland \\
\hline 10 & 2003 & Balsdon et al. & JUE ${ }^{\mathrm{e}}$ & 1 & Referendum & School spending & US \\
\hline 11 & 2004 & Brunner \& Balsdon & JUE ${ }^{\mathrm{e}}$ & 1 & Survey & School Spending & US \\
\hline 12 & 2004 & Thalmann & Public Choice & 3 & Survey & Green energy & Sweden \\
\hline 13 & 2005 & Hobolt & JEPOP ${ }^{f}$ & 8 & Survey & EU integration & DK, IE, NO ${ }^{n}$ \\
\hline 14 & 2005 & Rushton & $\mathrm{PBF}^{\mathrm{g}}$ & 1 & Referendum & Culture & US \\
\hline 15 & 2006 & Coates \& Humphreys & $J U E^{e}$ & 3 & Referendum & Sports & US \\
\hline 16 & 2006 & Kotchen \& Powers & $J_{E E M}^{b}$ & 3 & Referendum & Open space & US \\
\hline 17 & 2007 & Dehring et al. & Working paper & 3 & Referendum & Transport & US \\
\hline 18 & 2008 & Bornstein \& Lanz & $\mathrm{EE}^{\mathrm{h}}$ & 3 & Referendum & Green energy & Switzerland \\
\hline 19 & 2008 & Dehring et al. & $J_{U E}{ }^{e}$ & 1 & Referendum & Sports facility & US \\
\hline 20 & 2009 & Ahlfeldt \& Maennig & Working paper & 3 & Referendum & EU integration & DK, Sweden ${ }^{n}$ \\
\hline 21 & 2010 & Banzhaf et al. & JPAM $^{\mathrm{C}}$ & 1 & Referendum & Land conservation & US \\
\hline 22 & 2010 & Brunner \& Ross & JPubE ${ }^{i}$ & 1 & Referendum & School spending & US \\
\hline 23 & 2010 & Harsman \& Quigley & JPAM $^{\mathrm{C}}$ & 1 & Referendum & Road pricing & Sweden \\
\hline 24 & 2010 & Wu \& Cutter & $\mathrm{EE}^{\mathrm{h}}$ & 10 & Referendum & Various & US \\
\hline 25 & 2011 & Ahlfeldt & RSUE $^{\mathrm{j}}$ & 1 & Referendum & Urban development & Germany \\
\hline 26 & 2011 & Ahlfeldt \& Maennig & $U A R^{k}$ & 1 & Referendum & Sports facility & Germany \\
\hline 27 & 2012 & Heintzelman et al. & Working paper & 1 & Referendum & Growth boundaries & US \\
\hline 28 & 2013 & Wagschal & Book chapter & 1 & Referendum & Transport & Germany \\
\hline 29 & 2014 & Hersch \& Pelkowski & $A E L^{\prime}$ & 3 & Referendum & Fluoridated water & US \\
\hline 30 & 2015 & Ahlfeldt \& Maennig & JUE & 1 & Referendum & Transport & Germany \\
\hline 31 & 2015 & Coates \& Wicker & Working paper & 1 & Referendum & Sports & US \\
\hline 32 & 2015 & Horn et al. & CEPm & 3 & Referendum & Sports facility & US \\
\hline
\end{tabular}

Notes: . "N" indicates the number of referenda analyzed in a study; "Referendum" indicates the analysis of grouped data by voting precinct; and "Survey" indicates the analysis of individual data from post-referendum surveys, asking the same questions as those in the election. a Review of Economics and Statistics. b Journal of Environmental Economics and Management. c Journal of Policy Analysis and Management. d Social Science Quarterly. ${ }^{e}$

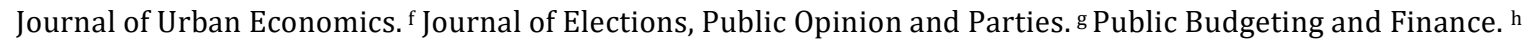
Ecological economics. ${ }^{i}$ Journal of Public Economics j Regional Science and Urban Economics. k Urban Affairs Review. ${ }^{1}$ Applied Economics Letters. ${ }^{m}$ Contemporary Economic Policy. ${ }^{n}$ ISO 2-alpha codes. For further details on the referenda and full references, consider Table A1 in Appendix I.

\subsection{Elderly attitudes}

Coding the relevant characteristics of the considered studies is a critical issue in quantitative literature review (Hunter and Schmidt, 1990). In the present study, this task is particularly challenging, since the definition of an individualistic attitude by the elderly depends on the topic, context, and specific question asked in a referendum. To categorize the attitude expressed by the elderly in a referendum, we proceed as follows. If the age effect revealed in a referendum analysis is qualitatively consistent with a narrowly defined self-interest by the elderly, as well as statistically significant, we code the elderly attitude as individualistic. If a referendum analysis yields a statistically insignificant 
age effect, we code the elderly's attitude as neutral. If the age effect is statistically significant and points toward the opposite direction of what we would code as individualistic, we code the elderly's attitude as collectivistic. The terms individualistic and collectivistic are borrowed from psychology literature, which analyzes the extent to which individuals give priority to personal (individualistic) or group (collectivistic) goals (Oyserman et al., 2002; Triandis, 1995).

To give some examples, an elderly voter with individualistic attitudes should be less concerned about housing affordability and job creation (Fischel, 1979), and prefer spending on health systems over state schools (Rubinfeld, 1977). More generally, such a voter will give relatively low priority to investments in durable capital stock, such as infrastructure or measures that seek to mitigate climate change. In Table 2, we summarize how we define an individualistic attitude by the elderly for a number of categories into which the analyzed referenda can be grouped. In Table A1 in Appendix I, we document how we coded the elderly attitudes in each of the referenda considered, accompanied by a rationale for every special case.

\section{Tab. 2. Definition of individualistic attitude by elderly voters compared to other voters}

\begin{tabular}{|c|c|c|}
\hline Category & $\mathrm{N}$ & Definition of individualistic elderly attitude \\
\hline Culture $^{a}$ & 3 & No definition required since elderly attitude is neutral in all referenda \\
\hline Energy & 9 & Low priority to sustainable energy production \\
\hline Environment $^{\mathrm{a}}$ & 3 & Low priority to environmental sustainability (e.g., natural habitat preservation) \\
\hline Foreign aid ${ }^{\mathrm{a}}$ & 1 & No definition required since elderly attitude is neutral in all referenda \\
\hline Health services & 5 & Incentives to increase health expenditures and reduce threats to (elderly) health \\
\hline Infrastructure ${ }^{b}$ & 4 & Low priority to large public investments in durable capital stock \\
\hline Integration & 11 & $\begin{array}{l}\text { Limited incentives to support political integration associated with potential long- } \\
\text { term economic benefits (trade, specialization) and short-term adjustment costs }\end{array}$ \\
\hline Law enforcement ${ }^{\mathrm{a}}$ & 1 & No definition required since elderly attitude is neutral in all referenda \\
\hline School spending & 15 & Low priority to expenditures on education \\
\hline Sports facility & 11 & Low priority to large public investments in durable capital stock \\
\hline Transport $^{\mathrm{b}}$ & 11 & Low priority to large public investments in durable capital stock \\
\hline Urban development ${ }^{\mathrm{b}}$ & 7 & Low priority to job creation or housing affordability \\
\hline Welfare $^{\mathrm{a}}$ & 2 & No definition required since elderly attitude is neutral in all referenda \\
\hline
\end{tabular}

Notes: a Merged into category “Other." b Merged into category “Transport and infrastructure." "N" indicates the number of referenda in a category. Elderly attitude is neutral if age effect is insignificant. A specific description of the individual decision rule, including some special cases, is included in Appendix I.

It is possible that the attitudes of the elderly are not only determined by a trade-off between selfinterest and altruism, but also to a phenomenon that is frequently observed in political economics literature, the status quo bias. This phenomenon has been described as a tendency of the electorate to oppose policies, even if they are apparently welfare-enhancing (Fernandez and Rodrik, 1991; Kahneman et al., 1991). It is theoretically possible that the elderly are particularly prone to such a bias. For one thing, the elderly seem to be more risk-averse than other generations (Mather et al., 2012). Thus, the elderly may exhibit a stronger status quo bias simply by habituation. To distinguish 
an individualistic elderly attitude from an elderly status quo bias, we also encode the elderly's attitude with respect to change in each referendum. Unlike with the coding of individualistic and collectivistic attitudes, the rule is relatively straightforward. A status quo attitude implies that the elderly, in relative terms, support legislations that would preserve the current situation and oppose those implying change. Likewise, an attitude in favor of change implies that the elderly, in relative terms, support legislations that seek to change the current situation and oppose those that do not.

\subsection{Results}

Figure 1 summarizes the distribution of the encoded attitudes separately for referenda held in Europe (EU) and in the US. In about 49\% of the considered referenda, the elderly voting behavior is in line with our interpretations of generational self-interest. This percentage is somewhat larger for the US (58\%) than for the EU (38\%). The opposite is true in less than $10 \%$ of the cases, with the remaining referenda showing no significant age effect. We find a similarly pronounced status quo orientation (43\%), which, again, is stronger in the US than in the EU ( $49 \%$ vs. 35\%, respectively). While individualistic preferences go hand in hand with status-quo orientation in many referenda, there are also a number of referenda where the elderly voted for a change in legislation to achieve a favorable outcome, suggesting that the status quo is not the only determinant of elderly voting behavior. 


\section{Fig. 1. Elderly attitudes in referenda by world region}

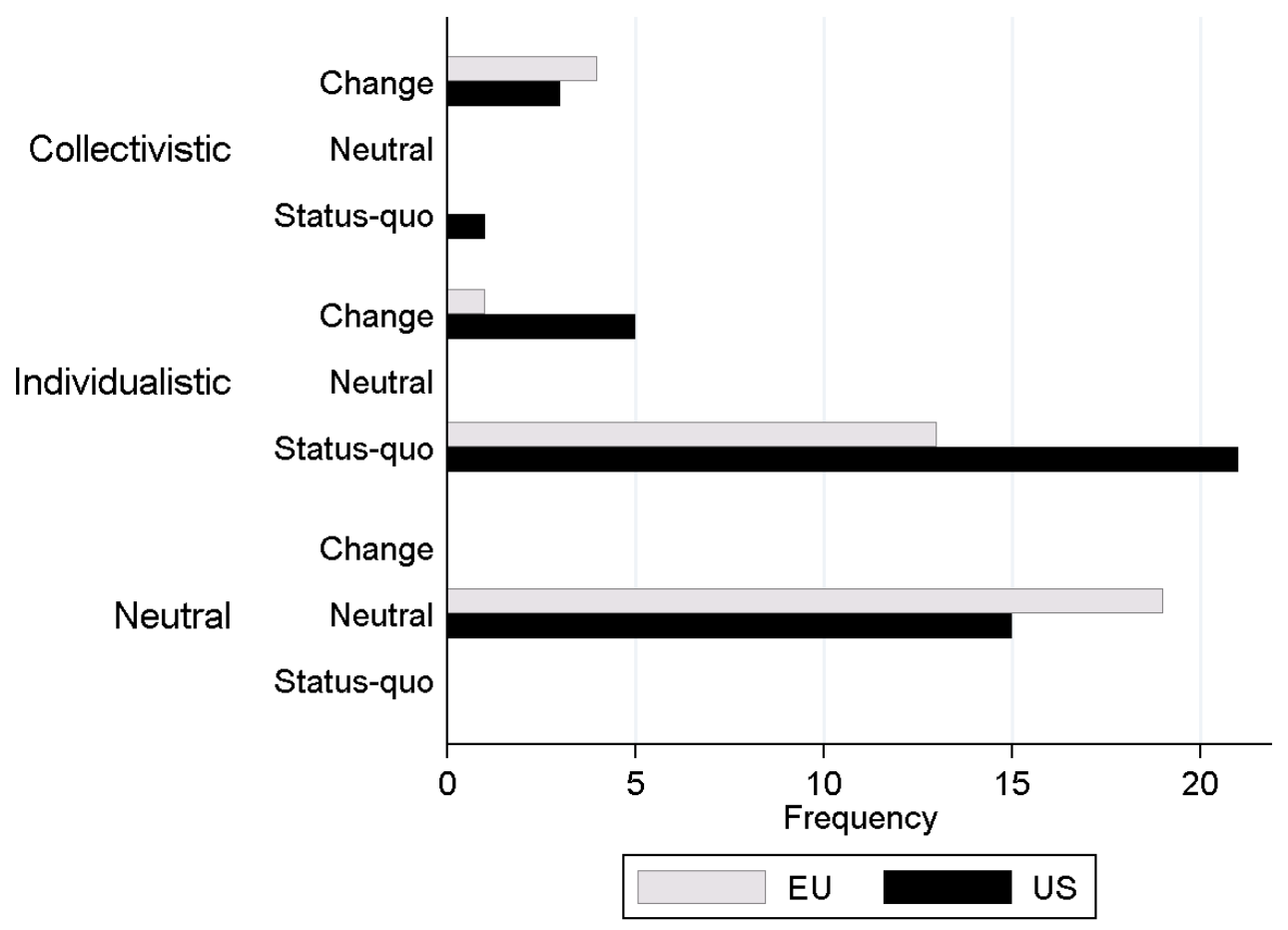

Notes: Elderly attitude is individualistic, if the age effect is in line with the results in Table 2 as well as statistically significant; collectivistic, if the age effect is in the opposite direction and statistically significant; and neutral (main categories), if the age effect is insignificant. Further, elderly attitude is change (status-quo) if the age effect is significant and points in the direction of changing (maintaining) the status quo. Elderly attitude is neutral (sub categories) if age effect is insignificant.

In Figure 2, we illustrate the distribution of the elderly's attitudes by referendum categories. One impressive insight is that in none of the 15 analyzed referenda on school spending (14 of which were conducted in the US), were the elderly more likely to support spending on schools than were other groups. In only three cases, there were no significant effects found, while the remaining 12 studies showed evidence of generational self-interest. Interestingly, the collective body of evidence emerging from referendum analyses provides a clearer pattern than does the literature that has correlated expenditures on public schools with demographic structures at different spatial levels, which has provided mixed results (Harris et al., 2001; Ladd and Murray, 2001; Poterba, 1998). This may suggest that, with the present age structure, the elderly may not generally be the decisive voters, which may change as the ageing of society progresses. Similarly, clear tendencies of individualistic preferences by the elderly are evident in referenda on (green) energy and health services. Moreover, individualistic voting is the most frequent elderly attitude for referenda on transportation, other infrastructure (e.g., water supply), and urban development (e.g., urban growth boundaries), but this tendency is not as strong as with the previously discussed categories. For those other categories, the elderly attitudes 
expressed in referenda are more ambiguous, showing no or weak signs of systematic generational self-interest.

Fig. 2. Elderly attitudes by category

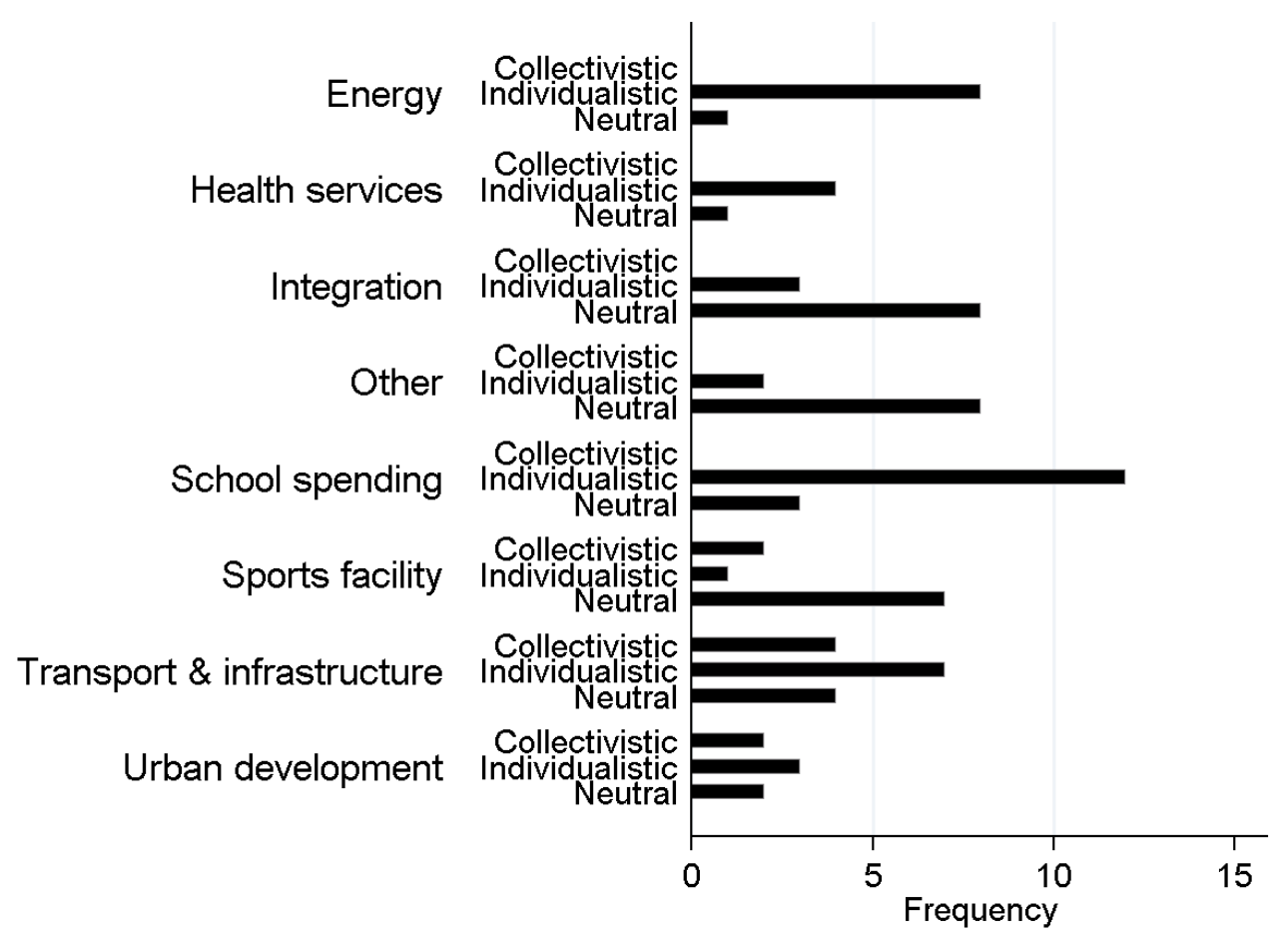

Notes: Elderly attitude is individualistic, if the age effect in line with the results in Table 2 , as well as statistically significant; collectivistic if the age effect is in the opposite direction and statistically significant; and neutral if the age effect is insignificant. "Other" includes referenda on culture, foreign aid, law enforcement, and welfare.

Additionally, in Table 3 we differentiate the elderly attitudes in public referenda by the categories discussed above, the world region, type of data analyzed, and publication year. We choose the publication year (rescaled to a zero value in 2000) instead of the year of the referendum because, in some cases, pooled estimates over a number of referenda were published, making it difficult to assign an exact year to a referendum. Notably, there is a strong tendency in the literature to analyze referenda relatively shortly after they are conducted, so that referendum and publication years are highly correlated.

In Column (1) of Table 3, we regress a categorical index, taking the value of $-1 / 0 /+1$ for collectivistic / neutral / individualistic attitudes, against dummy variables denoting each of the referendum categories; the type of data (survey vs. grouped precinct); whether a referendum was held in the US; whether a study was recommended to us by colleagues; and a yearly trend variable, taking a zero value in 2000. Because we omit the constant, the category coefficients can be interpreted as condi- 
tional means of the dependent variable within categories. In line with Figure 2, we find that the conditional means of our elderly preference variable lean significantly toward individualistic for Energy, Health services, and School spending; these effects are robust to adding country-fixed effects (Column (2)). The conditional means in Health services and School spending become statistically non-distinguishable from zero, once observations are weighted so that each study (and not referendum analysis) carries a similar weight, suggesting that the results are driven by studies analyzing multiple referenda (Column (3)). As expected, the elderly attitude toward the status quo is a strong predictor of individualistic elderly preferences across referenda (Column (4)). This is in line with an unconditional polychoric correlation of 0.67 (standard error $=0.1$ ) between the two variables. However, the conditional means of Energy, Health services, and School spending remain significantly larger than zero, even after controlling for status-quo orientation. In Columns (4) and (5), we rerun the models of Columns (1) and (2) using the index of status-quo orientation as the dependent variable. We do not find a significant status-quo orientation in neither the referenda on school spending, nor, after reweighting the observations, those on health services. Instead, we find a significant status-quo preference in referenda on questions related to European integration. Together with the results of Column (4), these results substantiate the impression that the strong tendency of individualistic voting in a number of categories is difficult to rationalize with status-quo bias alone. 
Tab. 3. Elderly attitudes: Multivariate analysis

\begin{tabular}{|c|c|c|c|c|c|c|}
\hline & $(1)$ & $(2)$ & (3) & (4) & $(5)$ & (6) \\
\hline & \multicolumn{4}{|c|}{$\begin{array}{c}\text { Attitude: } 1 \text { = Individualistic, } 0=\text { Neutral, } \\
-1=\text { Collectivistic }\end{array}$} & \multicolumn{2}{|c|}{$\begin{array}{c}\text { Attitude: } 1 \text { = Status- } \\
\text { quo, } 0 \text { = Neutral, } \\
-1=\text { Change }\end{array}$} \\
\hline & OLS & OLS & WLS & OLS & OLS & WLS \\
\hline Energy (dummy) & $\begin{array}{l}0.915^{* * *} \\
(0.238)\end{array}$ & $\begin{array}{l}1.010^{* * *} \\
(0.227)\end{array}$ & $\begin{array}{l}0.661^{* *} \\
(0.312)\end{array}$ & $\begin{array}{l}0.423^{*} \\
(0.215)\end{array}$ & $\begin{array}{l}0.852^{* * *} \\
(0.226)\end{array}$ & $\begin{array}{l}0.560^{* *} \\
(0.272)\end{array}$ \\
\hline Health services (dummy) & $\begin{array}{l}0.658^{* *} \\
(0.297)\end{array}$ & $\begin{array}{l}0.983^{* *} \\
(0.406)\end{array}$ & $\begin{array}{l}0.504 \\
(0.350)\end{array}$ & $\begin{array}{l}0.291^{*} \\
(0.153)\end{array}$ & $\begin{array}{l}0.636^{*} \\
(0.326)\end{array}$ & $\begin{array}{l}0.361 \\
(0.404)\end{array}$ \\
\hline Integration (dummy) & $\begin{array}{l}0.441 \\
(0.323)\end{array}$ & $\begin{array}{l}0.416 \\
(0.522)\end{array}$ & $\begin{array}{l}0.479 \\
(0.344)\end{array}$ & $\begin{array}{l}0.104 \\
(0.245)\end{array}$ & $\begin{array}{l}0.584^{*} \\
(0.307)\end{array}$ & $\begin{array}{l}0.727^{* *} \\
(0.303)\end{array}$ \\
\hline Other (dummy) & $\begin{array}{l}0.109 \\
(0.208)\end{array}$ & $\begin{array}{l}0.446 \\
(0.349)\end{array}$ & $\begin{array}{l}-0.016 \\
(0.164)\end{array}$ & $\begin{array}{l}0.028 \\
(0.109)\end{array}$ & $\begin{array}{l}0.140 \\
(0.217)\end{array}$ & $\begin{array}{l}0.015 \\
(0.185)\end{array}$ \\
\hline School spending (dummy) & $\begin{array}{l}0.598^{*} \\
(0.336)\end{array}$ & $\begin{array}{l}0.994^{* *} \\
(0.474)\end{array}$ & $\begin{array}{l}0.547 \\
(0.366)\end{array}$ & $\begin{array}{l}0.363^{*} \\
(0.206)\end{array}$ & $\begin{array}{l}0.407 \\
(0.362)\end{array}$ & $\begin{array}{l}0.309 \\
(0.372)\end{array}$ \\
\hline Sports facility (dummy) & $\begin{array}{l}-0.264 \\
(0.248)\end{array}$ & $\begin{array}{l}0.148 \\
(0.397)\end{array}$ & $\begin{array}{l}-0.272 \\
(0.289)\end{array}$ & $\begin{array}{l}-0.080 \\
(0.135)\end{array}$ & $\begin{array}{l}-0.318 \\
(0.270)\end{array}$ & $\begin{array}{l}-0.320 \\
(0.307)\end{array}$ \\
\hline $\begin{array}{l}\text { Transportation \& infra- } \\
\text { structure (dummy) }\end{array}$ & $\begin{array}{l}0.061 \\
(0.303)\end{array}$ & $\begin{array}{l}0.444 \\
(0.427)\end{array}$ & $\begin{array}{l}0.197 \\
(0.363)\end{array}$ & $\begin{array}{l}0.059 \\
(0.139)\end{array}$ & $\begin{array}{l}0.003 \\
(0.318)\end{array}$ & $\begin{array}{l}0.074 \\
(0.375)\end{array}$ \\
\hline $\begin{array}{l}\text { Urban development } \\
\text { (dummy) }\end{array}$ & $\begin{array}{l}-0.064 \\
(0.390)\end{array}$ & $\begin{array}{l}0.427 \\
(0.524)\end{array}$ & $\begin{array}{l}-0.146 \\
(0.381)\end{array}$ & $\begin{array}{l}0.094 \\
(0.434)\end{array}$ & $\begin{array}{l}-0.273 \\
(0.432)\end{array}$ & $\begin{array}{l}-0.206 \\
(0.409)\end{array}$ \\
\hline $\begin{array}{l}\text { US referendum } \\
\text { (base EU) }\end{array}$ & $\begin{array}{l}0.282 \\
(0.260)\end{array}$ & & $\begin{array}{l}0.222 \\
(0.279)\end{array}$ & $\begin{array}{l}0.173 \\
(0.141)\end{array}$ & $\begin{array}{l}0.188 \\
(0.263)\end{array}$ & $\begin{array}{l}0.198 \\
(0.266)\end{array}$ \\
\hline Survey data (dummy) & $\begin{array}{l}-0.129 \\
(0.197)\end{array}$ & $\begin{array}{l}0.101 \\
(0.192)\end{array}$ & $\begin{array}{l}0.218 \\
(0.235)\end{array}$ & $\begin{array}{l}0.249 \\
(0.201)\end{array}$ & $\begin{array}{l}-0.653^{* *} \\
(0.253)\end{array}$ & $\begin{array}{l}-0.254 \\
(0.305)\end{array}$ \\
\hline $\begin{array}{l}\text { Recommended study } \\
\text { (dummy) }\end{array}$ & $\begin{array}{l}-0.063 \\
(0.176)\end{array}$ & $\begin{array}{l}0.037 \\
(0.170)\end{array}$ & $\begin{array}{l}-0.115 \\
(0.186)\end{array}$ & $\begin{array}{l}-0.118 \\
(0.115)\end{array}$ & $\begin{array}{l}0.095 \\
(0.211)\end{array}$ & $\begin{array}{l}-0.264 \\
(0.229)\end{array}$ \\
\hline Year - 2000 & $\begin{array}{l}-0.002 \\
(0.008)\end{array}$ & $\begin{array}{l}0.009 \\
(0.008)\end{array}$ & $\begin{array}{l}0.004 \\
(0.007)\end{array}$ & $\begin{array}{l}-0.008 \\
(0.005)\end{array}$ & $\begin{array}{l}0.011 \\
(0.010)\end{array}$ & $\begin{array}{l}0.023^{* *} \\
(0.010)\end{array}$ \\
\hline $\begin{array}{c}\text { Attitude: } 1 \text { = Status-quo, } 0 \\
\quad=\text { Neutral, }-1=\text { Change }\end{array}$ & & & & $\begin{array}{l}0.578^{* * *} \\
(0.129)\end{array}$ & & \\
\hline Country effects & - & Yes & - & - & - & - \\
\hline Observations & 82 & 82 & 82 & 82 & 82 & 82 \\
\hline$R^{2}$ & 0.486 & 0.581 & 0.496 & 0.693 & 0.379 & 0.332 \\
\hline
\end{tabular}

Notes: Regressions exclude constants to allow for category-specific intercepts. WLS estimates are weighted by the inverse of the number of referenda in a study. Robust standard errors are in parentheses. ${ }^{*} p<0.1,{ }^{* *} p<0.05$, ${ }^{* * *}$ $p<0.01$.

\section{Case study}

\subsection{Background on Stuttgart 21 referendum}

The Magistrale for Europe, a high speed rail (HSR) that runs from Paris, France to Bratislava, Slovakia, is a central element of the Trans-European Transport Network (TEN-T). This corridor requires an HSR connecting the German state capitals of Munich (Bavaria) and Stuttgart (Baden-Württemberg). In order to increase capacity and reduce travel time on the HSR, the redevelopment of Stuttgart's central stub-end terminal station into an underground through station was proposed. After the first 
plans were presented in 1994, it took more than 10 years to reach an agreement on a financing concept. Eventually, the project became a public-private partnership with mixed funding coming from the rail carrier Deutsche Bahn, German federal state, state of Baden-Württemberg, city of Stuttgart, and other stakeholders such as the Stuttgart airport. The final plans for the new station, routing of the feeder lines, and tunnel work were presented in early 2005. By April 2006, all legal appeals against the project were rejected (Stuckenbrock, 2013).

After the construction work on Stuttgart 21, the official title of the project, started in February 2010, protests against the project steadily increased, even reaching the traditionally non-agitated milieus. The "Wutbürger," meaning enraged citizen, emerged as a popular expression to describe this new phenomenon (Kurbjuweit, 2010). On September 30th, conflicts with authorities escalated during an attempt by police forces to clear an occupied public park in the immediate vicinity of the building site, resulting in 116 injuries (Stuckenbrock, 2013). The projected costs amounted to $€ 6.5(\$ 9,2011$ exchange rate) billion in the Stuttgart metropolitan region alone. Even in a wealthy federal state with a 2011 GDP per capita close to that of New York, these costs were perceived by many as excessive. ${ }^{8}$ Moreover, the construction period was expected to last at least 10 years, during which significant disruptions were expected, in particular, for the regional commuter rail network. Proponents argued that the costs were justified in light of the expected travel-cost savings, expected creation of jobs, and potential revenues and opportunities for urban development, resulting from the redevelopment of the former track beds (Wagschal, 2013).

After the state elections in March 2011, the leading green party and social democrats formed a coalition. Since a central position of the green party was to oppose Stuttgart 21, while the social democrats supported the project, the parties agreed to delegate the decision to the voters in a public referendum. On November 27th, about 7.6 million eligible voters in Baden-Württemberg were called to the ballots to decide whether the state should exercise its right to withdraw the €930 million (\$1.3 billion) contribution to the project. A yes vote, thus, implied a vote against Stuttgart 21. Backed by a relatively high turnout of $48.3 \%$, an unexpected yet clear majority of $58.9 \%$ voted no and, therefore, in favor of one of Germany's largest infrastructure projects in the foreseeable future.

8 In 2011, Baden-Württemberg had a GDP per capita of €35,802 or $\$ 49,851$, taking the mean $2011 \$ / €$ exchange rate as a basis. As a comparison, New York had a GDP per capita of $\$ 52,657$, ranking $7^{\text {th }}$ in the US. 


\subsection{Empirical strategy}

In analyzing the Stuttgart 21 referendum, we assume that voters who participate in a public referendum support the alternative that maximizes their expected utility. Central to our interest is the relationship between expected utility and voter age. Our competing hypotheses are consistent with those examined in the quantitative literature review. Narrow self-interest would suggest that the probability of opposing Stuttgart 21 should increase with age. Moreover, the expected net present value should decrease with age, since a lower life expectancy implies shorter exposure to the benefits (travel-time savings) and, in relative terms, stronger exposure to costs (disruptions). Any positive wider economic impacts are also less immediately relevant to voters who are already retired or expect to be retired in the near future..$^{9}$ Intergenerational altruism or an interest in maintaining a strong economy to sustain the pension and health systems potentially compensates for these incentives. Experience with similar projects in the past combined with a sense of morale could theoretically imply that the likelihood of support could increase with age, if the project is perceived as socially desirable. ${ }^{10}$

To examine the relationship between expected utility and age, we follow what has become standard practice in the literature and relate the opposition to Stuttgart 21 in the referendum to the average age of the electorate, using a linear probability model (e.g., Ahlfeldt and Maennig, 2015; Brunner et al., 2001; Coates and Humphreys, 2006; Dehring et al., 2008):

$$
\operatorname{PRCNTYES}_{i}=\alpha+\beta A G E_{i}+\gamma S_{i}+X_{i} \mu+\varepsilon_{i}
$$

The opposition to Stuttgart 21 is expressed as the percentage of yes votes of the total votes for municipality $i$ (PRCNTYES). $A G E_{i}$ is the average age of the adult population that is entitled to participate in the referendum. We add a variable, $S$, to the model, which captures the degree to which a municipality's accessibility is upgraded. We experiment with different measures, described in more detail in the data section, including the straight-line distance from Stuttgart and a gravity measure, which

9 The transport appraisal literature distinguishes between user benefits, which mainly capture the value of shorter travel times, and wider economic impacts, such as agglomeration benefits due to higher effective density, moves to more productive jobs, and output changes in imperfectly competitive markets (Department for Transport, 2014).

10 The transport appraisal for planned local transportation measures revealed a benefit-cost ratio of 2.95 (Verkehrswissenschaftliches Institut Stuttgart and Intraplan Consult, 2006). 
incorporates the expected changes in the bilateral connectivity as well as the bilateral commuting probabilities between municipalities.

Since voters' attitudes in public referenda are likely shaped by the economic situation and sympathies (Brunner et al., 2011), we add a vector of further covariates, $X$. With these controls, we seek to disentangle the age effect from the effects related to the economic conditions, education of the electorate, and lifestyles and attitudes that may differ between urban and rural areas. $\beta$ (of primary interest), $\gamma$, and $\mu$ (a vector) are the parameters to be estimated, and $\varepsilon_{i}$ is a random error term.

We note that the major political parties took clear positions in favor of or against Stuttgart 21, and it is possible that voters were influenced by affiliations to these parties. The problem with controlling for these effects is that sympathies for political parties and their agendas may depend on age. For example, voters of the conservative party, which supported Stuttgart 21, tend to be older than those of other parties in Germany (Kulick, 2011). Adding controls for political-party affiliation, thus, induces the risk of over-controlling, or creating a bad control problem (Angrist and Pischke, 2009). A similarly controversial control is a regional dummy for Baden to capture the potential tendency among its citizens to oppose a project that would benefit the state capital, Stuttgart, in Württemberg, due to a historic regional rivalry (Wagschal, 2013). ${ }^{11}$ The problem with this control is that it will absorb the effect of any difference in the average age between citizens of Baden and Württemberg, and attribute its effect to the suspected regional rivalry, even if, in reality, it did not exist. For these reasons, we will refer to estimated age effects that do not control for party affiliation and region as upper-bound estimates, and to estimated age effects that are conditional on these political controls as lower-bound estimates. We will use both (and further) estimates in our simulations of the effect of population ageing.

Besides the baseline linear probability model described in Equation (1), we estimate a variety of alternative specifications that address distinct econometric concerns. To allow for arbitrary spatial autocorrelation between neighboring communities, we adjust the standard errors according to Conley (1999). ${ }^{12}$ We use turnout as both a dependent and explanatory variable and, in the latter case, use

${ }^{11}$ Throughout our analysis, we refer to Baden as the area of today's governorates (Regierungsbezirke) of Karlsruhe and Freiburg. Both of these administrative districts largely consist of areas that historically belong to the Baden region.

12 Weights in the covariance matrix estimator linearly decline from 1 to 0 , reaching 0 at the predefined cutoff point. For our models, we chose a cutoff of $15.6 \mathrm{~km}$, which corresponds to the average commuting distance in Baden-Württemberg in 2011 (Winkelmann, 2013). 
the turnout in an earlier election as an instrumental variable (Vlachos, 2004). Following a tradition in the public-choice literature, we estimate a weighted (by the number of participating voters) version (WLS) and a binary choice (BC) logit version of Equation (1) (Deacon and Shapiro, 1975; Kahn and Matsusaka, 1997; Schulze and Ursprung, 2000). Besides considering different measures to capture the accessibility effects, we also consider the share of the elderly (aged 65 and older) as an alternative age-related variable, which has been popular in the literature. Further, we experiment with the interactions between $A G E$ and all other covariates.

Intrinsic to the cross-sectional nature of Equation (1) is the concern that even after controlling for other factors there remains an unobserved component in the error term $\left(\varepsilon_{i}\right)$, which is correlated with the referendum outcome and the average age of the electorate. Moreover, a natural concern is that the elderly prefer living in certain municipalities where, regardless of age, voters tend to have a specific view on the project in question. Some examples that would give cause for concern include a particular preference for certain modes of transportation, the valuation of the environment, or attitude toward technological innovation, among other things, for which are difficult to control.

To explore the direction of a potential bias, we propose a 2SLS strategy and instruments that are correlated with age, but less likely correlated with the unobserved determinants of voting decisions, than with age itself. First, we consider the share of children (aged 0-6 and 6-15) in the total population in 1950 and 1961. These instruments will have some predictive power for the share of the elderly in 2011, if a significant fraction of the population stays put or returns to their birthplace after they retire. ${ }^{13}$ Second, we use the shares of the secondary and tertiary sectors of total employment in 1961, 1970, and 1987 (the last employment censuses in Germany before 2011). The intuition is that locations with, at some point in time, a favorable industry composition likely attracted a young mobile workforce. If a fraction of those movers then stayed put, historic sectoral shares should influence the contemporary age distribution. We note that, to satisfy the exclusion restriction, we include con-

13 In 2011, the cohort aged 0-15 in 1950 (1961) is aged 61-76 (72-87). We expect a significant cohort effect of the stayers because of the pronounced reduction in the fertility rate from 2.37 to 1.36 births per woman that occurred over the 1960-2011 period in Germany (The World Bank, 2015). 
temporary sectoral shares in all models, using these instruments, because of the likely serial correlation in industry structure. We also note that we use sectoral shares at the county level because these represent a better approximation of a labor market area than do very small municipalities. ${ }^{14}$

\subsection{Data}

To analyze the Stuttgart 21 referendum, we collect a variety of data from different sources at the level of the 1,101 municipalities (Gemeinden) of Baden-Württemberg. We obtain the numbers of valid yes and no votes cast, as well as the number of eligible voters, from the statistical office of Baden-Württemberg. ${ }^{15}$ The population by age, gender, and education (academic degree holders), as well as by home-ownership rate, is available on the 2011 census website (www.zensus2011.de). The unemployment rate and income (taxable income per capita), as well as shares of conservative and green party votes in the 2009 federal elections, comes from the regional statistics database of the Federal Statistical Office (www.regionalstatistik.de/genesis/online/logon). With the exception of the 2009 federal elections, this data refers to 2011. The historical population and employment data (for 1950, 1961, 1970, and 1987), consistent with the 2011 municipality definition, has been acquired from the Statistical Office of Baden-Württemberg. The 2011 sectoral shares are from the Federal Statistical Office.

All data at the municipality level, with the exception of the number of academic degree holders, which is not available for municipalities with a population of less than 10,000. Full coverage was provided at the next higher geographic level, counties (Kreise und kreisfreie Städte). Within each county, we distribute degree holders that we cannot directly allocate to municipalities with a population of at least 10,000 to the remaining municipalities, assuming the share of degree holders follows a spatial autoregressive process. ${ }^{16}$

A central variable in our empirical analysis is the average age of the adult population, which forms the electorate. The 2011 census contains detailed information on the number of residents within one-

14 Standard errors are, thus, clustered on counties in the respective models. Because the contemporary industry share effects, as shown in more detail below, are not significant, we omit these controls in all one-stage models.

15 Our data includes $3,663,639$ out of $3,668,372$ votes. The remaining portion of less than $0.23 \%$ are postal votes in the small municipalities, which occasionally share a common voting district for votes by mail.

16 In interpolating the share of degree holders, we give higher weights to closer municipalities, using the following inverse exponential weights function: $w_{i j}=\exp \left(-\tau \times d_{i j}\right)$, where $\tau$ is a commuting decay parameter, estimated and discussed in more detail in Section 2 of Appendix II, and $d_{i j}$ is the distance between municipalities $i$ and $j$. 
year age bins (e.g., 18, 19, 20, etc. years) for every municipality. The average age of the adult population, thus, can be computed as the average of all age bins, starting with the age of 18 , weighted by their respective shares of the adult population.

To create a measure of population density, we use the geographic surface area of the municipalities, provided by the Federal Statistical Office. Using a geographic information system (GIS) and electronic map provided by the Federal Agency for Cartography and Geodesy, we generate various distance measures, which strictly refer to the geographic centroids of the municipalities. To approximate the accessibility to Stuttgart 21, we compute the crow-flight distance from Stuttgart to each municipality.

In addition, as a more explicit measure of the expected long-term net-benefits of Stuttgart 21, we compute a gravity measure for each municipality's (weighted) average change in travel time to all other municipalities in Baden-Württemberg. In computing this measure for a given municipality we weight the expected change in travel time to another municipality by the respective commuting share. ${ }^{17}$ The expected travel-time changes are based on SMA und Partner AG (2010), a commissioned study that was accessed through the Department of Transport and Infrastructure of the State of Baden-Württemberg. A more detailed description of this measure is found in Appendix II, and the descriptive statistics of all variables are presented in Table 4.

17 Formally, the expected change in travel time $\Delta_{i}$ for municipality $i$ is defined as follows: $\Delta_{i}=\sum_{j} \frac{c_{i j}}{\sum_{j} c_{i j}} \Delta_{i j}$, where $\Delta_{i j}$ is the expected change in travel time between the two municipalities $i$ and $j$, and $c_{i j}$ is the number of workers commuting from $i$ to $j$. 
Tab. 4. Summary statistics

\begin{tabular}{|c|c|c|c|c|c|}
\hline Variable & Description & Mean & S.D. & Min. & Max. \\
\hline \multicolumn{6}{|l|}{ Dependent variables } \\
\hline Yes & Yes votes in Stuttgart 21 referendum (\%) & 36.85 & 9.76 & 4.90 & 66.45 \\
\hline Turnout & Voter turnout in Stuttgart 21 referendum (\%) & 48.81 & 8.87 & 25.74 & 80.51 \\
\hline \multicolumn{6}{|l|}{ Age variables } \\
\hline Average age & Average age of adult population (years) & 50.12 & 1.41 & 44.10 & 59.25 \\
\hline Age $>65$ & Share of adult population aged above 65 & 23.12 & 3.11 & 13.84 & 44.36 \\
\hline \multicolumn{6}{|l|}{ Socio-economic controls } \\
\hline Male & Share of male population (\%) & 49.09 & 1.34 & 34.00 & 59.21 \\
\hline Income & Total taxable income / population (1000 €) & 17.29 & 2.44 & 11.33 & 34.07 \\
\hline Unemployment & $\begin{array}{l}\text { Registered unemployed / workforce }(15 \leq \text { age }<65) \\
(\%)\end{array}$ & 2.49 & 0.83 & 0.53 & 6.43 \\
\hline Homeowner & Share of owner-occupied dwellings (\%) & 64.17 & 9.33 & 26.61 & 91.78 \\
\hline Degree share & Share of workforce holding an academic degree (\%) & 12.07 & 3.35 & 4.72 & 34.14 \\
\hline Density & Population density (100 people per $\mathrm{km}^{2}$ ) & 3.14 & 3.28 & 0.18 & 28.26 \\
\hline \multicolumn{6}{|l|}{ Political controls } \\
\hline Conservatives & Share of conservative party votes $(\%)^{\mathrm{a}}$ & 37.41 & 6.09 & 21.47 & 66.96 \\
\hline Greens & Share of green party votes $(\%)^{\mathrm{a}}$ & 11.87 & 3.23 & 1.39 & 27.25 \\
\hline \multicolumn{6}{|l|}{ Spatial variables } \\
\hline Distance to Stuttgart & Distance to central Stuttgart $(\mathrm{km})$ & 74.64 & 37.44 & 0.00 & 175.12 \\
\hline \multirow[t]{2}{*}{ Delta travel time } & Average change in commuting time (minutes) & -0.92 & 2.17 & - & 8.70 \\
\hline & & & & 24.71 & \\
\hline \multicolumn{6}{|c|}{ Controls used in 2SLS models } \\
\hline Secondary sector 2011 & Share of secondary sector of employment in 2011 & 44.51 & 7.56 & 14.40 & 63.30 \\
\hline Tertiary sector 2011 & Share of tertiary sector of employment in 2011 & 54.96 & 7.53 & 36.50 & 85.50 \\
\hline \multicolumn{6}{|l|}{ Instruments } \\
\hline Turnout 2009 & Voter turnout in 2009 federal election (\%) & 70.87 & 4.64 & 53.30 & 87.90 \\
\hline Secondary sector 1961 & Share of secondary sector of employment in 1961 & 49.27 & 14.43 & 9.41 & 83.12 \\
\hline Tertiary sector 1961 & Share of tertiary sector of employment in 1961 & 20.35 & 9.74 & 1.82 & 77.56 \\
\hline Secondary sector 1970 & Share of secondary sector of employment in 1970 & 54.66 & 13.59 & 12.15 & 87.20 \\
\hline Tertiary sector 1970 & Share of tertiary sector of employment in 1970 & 28.33 & 10.32 & 6.25 & 79.29 \\
\hline Secondary sector 1987 & Share of secondary sector of employment in 1987 & 51.42 & 10.09 & 17.77 & 84.90 \\
\hline Tertiary sector 1987 & Share of tertiary sector of employment in 1987 & 43.36 & 9.83 & 13.47 & 79.90 \\
\hline \multirow[t]{2}{*}{$\Delta$ Secondary sector $61-70$} & Change in secondary sectoral share 1961 to 1970 & 5.38 & 5.64 & - & 27.82 \\
\hline & & & & 11.12 & \\
\hline$\Delta$ Tertiary sector $61-70$ & Change in tertiary sectoral share 1961 to 1970 & 7.98 & 4.26 & -3.89 & 40.01 \\
\hline \multirow{2}{*}{$\Delta$ Secondary sector $70-87$} & Change in secondary sectoral share 1970 to 1987 & -3.24 & 8.76 & - & 28.87 \\
\hline & & & & 28.61 & \\
\hline$\Delta$ Tertiary sector $70-87$ & Change in tertiary sectoral share 1970 to 1987 & 15.03 & 4.95 & -6.49 & 44.51 \\
\hline Age $\leq 61950$ & Share of population aged 6 and under in 1950 & 8.82 & 1.26 & 3.97 & 24.60 \\
\hline $6<$ Age $\leq 151950$ & Share of population aged 6-15 in 1950 & 16.72 & 1.83 & 6.12 & 27.33 \\
\hline Age $\leq 61961$ & Share of population aged 6 and under in 1961 & 11.82 & 1.76 & 6.49 & 23.29 \\
\hline $6<$ Age $\leq 151970$ & Share of population aged 6-15 in 1961 & 13.90 & 1.87 & 8.64 & 23.27 \\
\hline
\end{tabular}

Notes: The descriptive statistics for all variables are shown in the original, non-centered scale. All variables, except political variables and instruments, are observed in 2011. a From the 2009 federal election.

\subsection{Baseline results}

Figure 3 maps the opposition against Stuttgart 21, based on the share of yes votes against the rail geography in Baden-Württemberg, including the proposed HSR to Munich. A visual inspection suggests that opposition increases with distance from the Stuttgart 21 project, which is in line with the 
lower expected accessibility gains. At second glance, a tendency of lower opposition along the proposed HSR becomes evident. While, theoretically, the HSR could be realized independently of Stuttgart 21, the two projects were often related to each other in the public debate. Therefore, it is possible that some voters who supported Stuttgart 21 in the referendum were actually supporting the HSR because the rejection of Stuttgart 21 might have threatened the HSR project.

\section{Fig. 3. Opposition to Stuttgart 21 project (share of yes votes)}

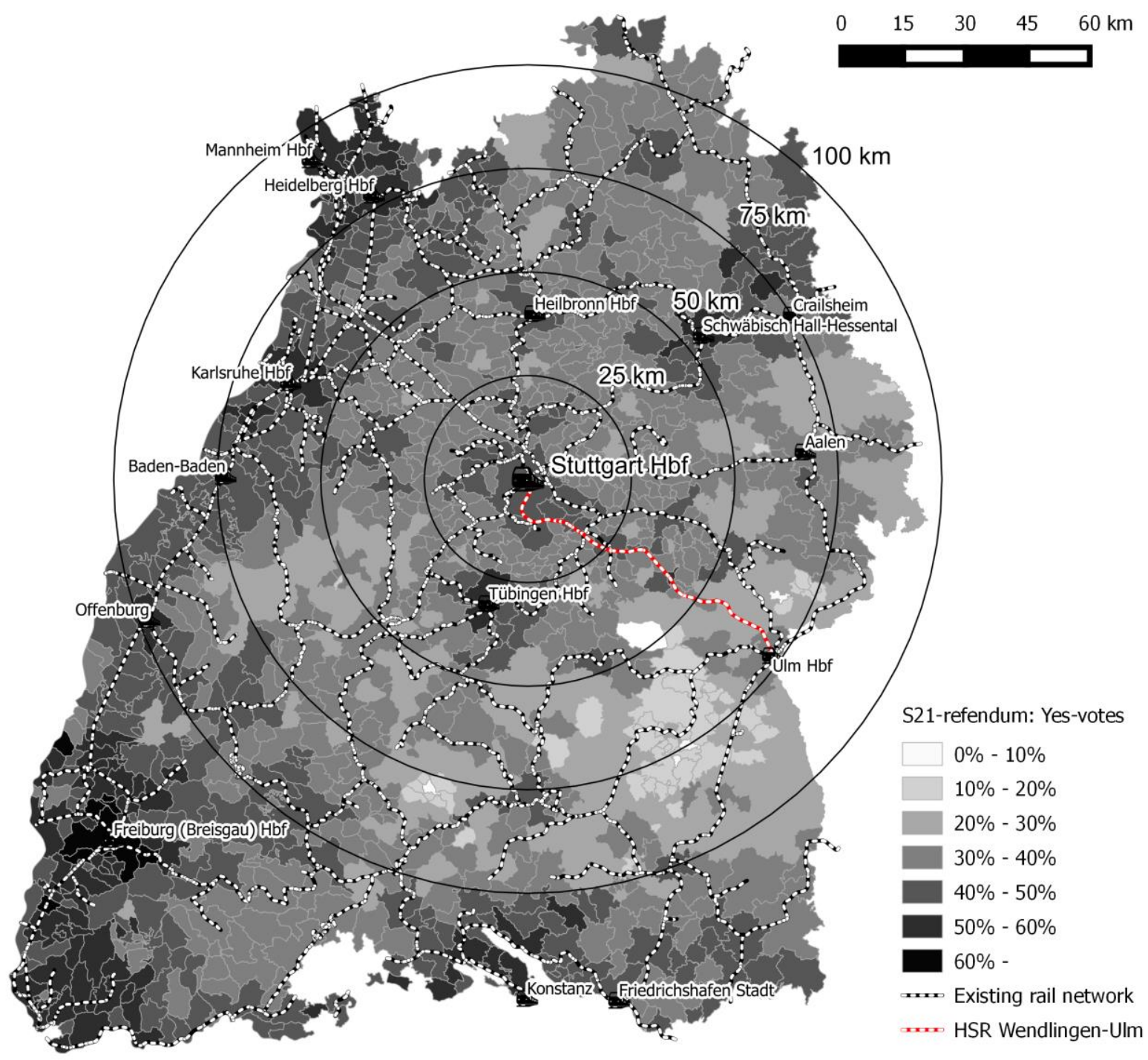

Notes: Own illustration based on DLM250-Geodata by the Federal Agency for Cartography and Geodesy. Geographic unit is municipalities.

In Figure 4, we turn our attention to the relationship between the opposition to Stuttgart 21 and average age of the electorate. The left panel displays a positive and unconditional raw correlation between the average age of the electorate and opposition to Stuttgart 21. A one-year increase in the average age of the electorate is associated with a 1.79-percentage-point higher share of opposing yes votes. This is in line with the hypothesis that the elderly vote in generational self-interest because 
the expected net present value of Stuttgart 21 should decline as voters age, if the benefits to other generations are ignored. Another notable, stylized fact is evident from Figure 4. Despite a relatively low average age, voters in some of the largest cities in the state, such as Freiburg, Heidelberg, Karlsruhe, and Mannheim, opposed Stuttgart 21. To some extent, this result can be rationalized by their relatively long distance from Stuttgart and the correspondingly low expected benefits. However, even in Stuttgart, the city that should accumulate the largest long-term benefits, there was a relatively large opposition, considering the average age of the electorate. This is suggestive of an urbanization effect, which could be driven by the particular values and attitudes of urban populations.

Therefore, it is reassuring that the conditions on the socio-economic controls of the voting outcome in the large cities is closer to the linear prediction, as evident from the right panel of Figure 4. Controlling for other determinants of the voting decision, the most evident outlier among the large cities is Ulm. As illustrated in Figure 3, Ulm lies on the planned HSR connecting Stuttgart and Munich and, to the extent that Stuttgart 21 and the HSR were perceived as complementary projects, voters in Ulm had an incentive to support Stuttgart 21. More generally, the correlation between the opposition to Stuttgart 21 and average age of the electorate remains reasonably strong when controlling for other factors. An increase in the average age by one year is associated with an increase in the share of yes votes by $1.17 \%$. Moreover, expressed as an elasticity at the means of the distributions, a $1 \%$ increase in the average age is associated with a $1.59 \%$ increase in the share of yes votes, which is a relatively large effect. The respective partial correlation controlling for political variables is found in Appendix II (Figure A4). 
Fig. 4. Correlation between share of yes votes and average age across municipalities
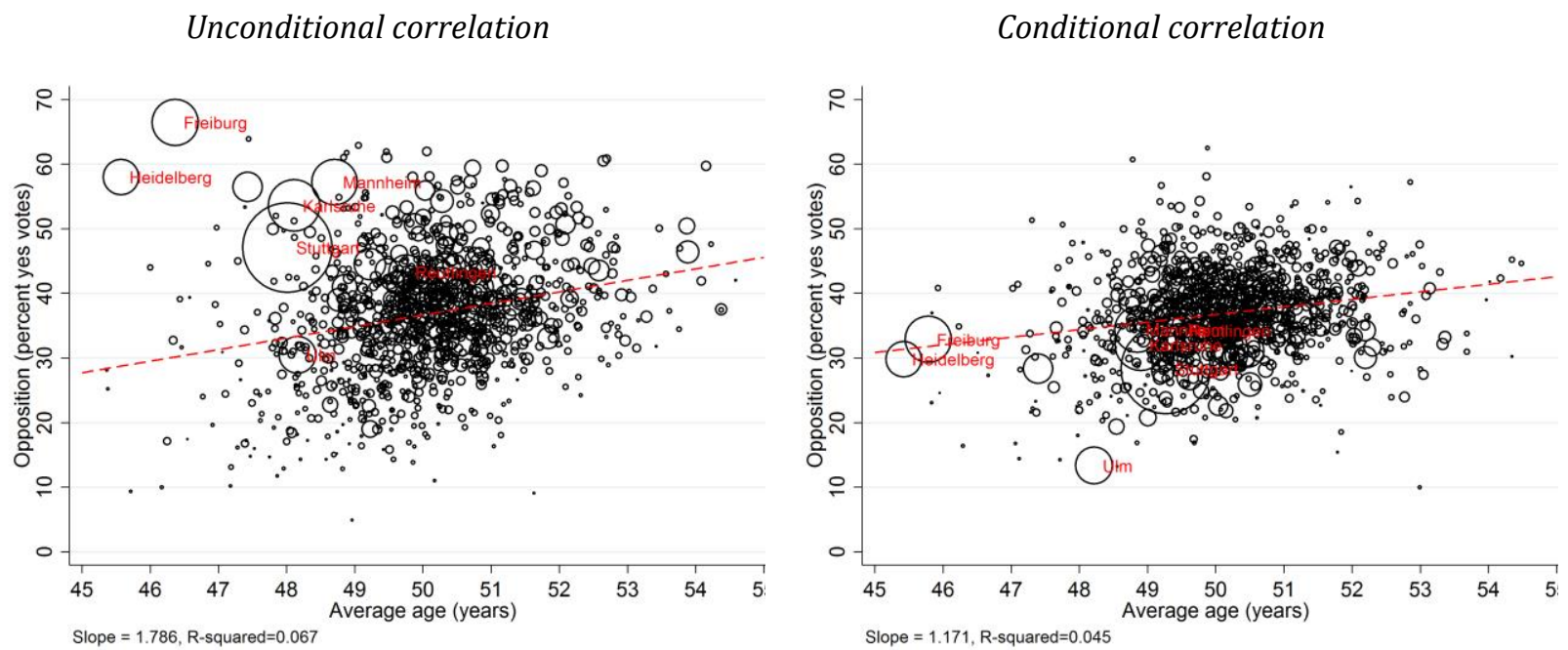

Notes: Average age refers to the adult population (electorate). The conditional correlation is based on the residuals of a regression of the share of yes votes against all covariates but age, and the residuals of a regression of age against the same covariates. The mean share of yes votes and mean age are added to the respective residuals to keep a consistent scale. The covariates include the share of male voters, share of degree holders, income, unemployment, homeownership, and distance from Stuttgart 21. A handful of outliers, in terms of age, is not displayed, to improve the presentation. The dashed lines are linear fits to all observations (including outliers), marker size is proportionate to the absolute number of votes, and largest cities are labeled.

In Table 5, we provide the results of the regressions of the share of yes votes (Columns (1)-(4)) and turnout (Columns (5)-(6)) against the average age and varying sets of covariates. Column (1) presents the bivariate estimates and corresponds to the left panel in Figure 4. One insight from the incremental extension of the bivariate model in the next columns is that, while proximity to Stuttgart 21 increases support for the project as expected, the addition of the control hardly impacts the age effect, implying a limited correlation between the two variables (Column (2)). In contrast, the age effect is reduced by about one third when our set of socio-economic control variables is added (Column (3)). The homeownership rate, share of academic degree holders, and population density are significant and, given relatively large standard deviations (see Table 4), empirically relevant predictors of the share of yes votes. To put the magnitude of the age effect into perspective, a ceteris paribus increase in the average age by 10 years (8.3 S.D.) has the same effect on the share of yes votes (11.7 percentage points) as does an increase in the distance from Stuttgart by $113.7 \mathrm{~km}$ (3.0 S.D.), an decrease in the homeownership rate by 39.6 percentage points (4.2 S.D.), an increase in the share of academic degree holders by 18.6 percentage points (5.6 S.D.), or an increase in population density by 3,235 residents per square $\mathrm{km}$ (9.9 S.D.).

Adding political controls leads to the expected effects. In line with the positions the parties took with respect to Stuttgart 21, a higher share of conservative party voters is associated with more support, 
while the opposite holds true for a higher share of green party voters. In addition, in line with the political rivalry hypothesis, the opposition to Stuttgart 21 in Baden exceeded that in Württemberg by a notable 5.4 percentage points (more than 10\%). As expected, the age effect is again reduced by about one third. A further analysis, reported in Appendix II (Table A1), indicates that both party variables, as well as the Baden dummy variable, individually reduce the age effect to 0.97 or 0.90 percentage points. Moreover, we find a significant conditional correlation between the average age and conservative vote shares, but not green vote shares. Similarly, the partial correlation between the Baden dummy variable and average age is statistically significant.

As such, we conclude that a one-year increase in the average age of the electorate, depending on the ceteris paribus condition imposed, increases the opposition to Stuttgart 21 by 0.71-1.17 percentage points, which is in line with an elderly vote in generational self-interest. The effect is unlikely driven by a higher or lower participation of the elderly in the referendum, as the age effect on the turnout tends to be small and not statistically significant (see Columns (5) and (6) in Table 5). For the interested reader, we present a broader range of turnout models in Appendix II (Table A2). 
Tab. 5. Determinants of opposition to Stuttgart 21: Baseline models

\begin{tabular}{|c|c|c|c|c|c|c|}
\hline & (1) & (2) & (3) & (4) & (5) & (6) \\
\hline & $\begin{array}{l}\text { Share yes } \\
\text { votes (\%) }\end{array}$ & $\begin{array}{l}\text { Share yes } \\
\text { votes (\%) }\end{array}$ & $\begin{array}{l}\text { Share yes } \\
\text { votes (\%) }\end{array}$ & $\begin{array}{l}\text { Share yes } \\
\text { votes (\%) }\end{array}$ & Turnout (\%) & Turnout (\%) \\
\hline \multirow[t]{3}{*}{ Average age (years) } & 1.786 & 1.641 & 1.171 & 0.711 & -0.077 & 0.274 \\
\hline & $(0.284)^{* * *}$ & $(0.273)^{* * *}$ & $(0.186)^{* * *}$ & $(0.131)^{* * *}$ & $(0.172)$ & $(0.135)^{* *}$ \\
\hline & {$[0.312]^{* * *}$} & {$[0.314]^{* * *}$} & {$[0.240]^{* * *}$} & {$[0.158]^{* * *}$} & [0.243] & {$[0.175]$} \\
\hline Distance from & & 0.091 & 0.103 & 0.076 & -0.131 & -0.116 \\
\hline \multirow[t]{2}{*}{ Stuttgart (km) } & & $(0.00656)^{* * *}$ & $(0.00656)^{* * *}$ & $(0.00457)^{* * *}$ & $(0.00541)^{* * *}$ & $(0.00558)^{* * *}$ \\
\hline & & {$[0.0161]^{* * *}$} & {$[0.0119]^{* * *}$} & {$[0.00638]^{* * *}$} & {$[0.0105]^{* * *}$} & {$[0.0101]^{* * *}$} \\
\hline \multirow[t]{3}{*}{ Male (\%) } & & & -0.093 & 0.209 & -0.208 & -0.257 \\
\hline & & & $(0.357)$ & (0.161) & $(0.205)$ & (0.161) \\
\hline & & & [0.339] & {$[0.163]$} & {$[0.207]$} & [0.171] \\
\hline Per capita income & & & 0.112 & -0.246 & 0.723 & 0.665 \\
\hline \multirow[t]{2}{*}{ (EUR) } & & & $(0.110)$ & $(0.0735)^{* * *}$ & $(0.0953)^{* * *}$ & $(0.0898)^{* * *}$ \\
\hline & & & [0.145] & {$[0.0947]^{* * *}$} & {$[0.125]^{* * *}$} & {$[0.103]^{* * *}$} \\
\hline Unemployment rate & & & 0.665 & 0.315 & -1.866 & -1.062 \\
\hline \multirow[t]{2}{*}{ (\%) } & & & $(0.341)^{*}$ & $(0.254)$ & $(0.309)^{* * *}$ & $(0.295)^{* * *}$ \\
\hline & & & {$[0.405]$} & {$[0.323]$} & {$[0.473]^{* * *}$} & {$[0.377]^{* * *}$} \\
\hline Homeownership rate & & & -0.296 & -0.112 & 0.184 & 0.192 \\
\hline \multirow{2}{*}{ (\%) } & & & $(0.0401)^{* * *}$ & $(0.0279)^{* * *}$ & $(0.0315)^{* * *}$ & $(0.0296)^{* * *}$ \\
\hline & & & {$[0.0607]^{* * *}$} & {$[0.0403]^{* * *}$} & {$[0.0466]^{* * *}$} & {$[0.0391]^{* * *}$} \\
\hline \multirow[t]{3}{*}{ Degree share (\%) } & & & 0.629 & 0.258 & 0.522 & 0.208 \\
\hline & & & $(0.0795)^{* * *}$ & $(0.0553)^{* * *}$ & $(0.0812)^{* * *}$ & $(0.0692)^{* * *}$ \\
\hline & & & {$[0.122]^{* * *}$} & {$[0.0771]^{* * *}$} & {$[0.152]^{* * *}$} & {$[0.119]^{*}$} \\
\hline Population density & & & 0.362 & 0.245 & -0.006 & 0.047 \\
\hline \multirow[t]{2}{*}{ (100 residents $/ \mathrm{km}^{2}$ ) } & & & $(0.0828)^{* * *}$ & $(0.0596)^{* * *}$ & $(0.0895)$ & $(0.0632)$ \\
\hline & & & {$[0.112]^{* * *}$} & {$[0.0740]^{* * *}$} & {$[0.148]$} & {$[0.0967]$} \\
\hline \multirow[t]{3}{*}{ Baden (dummy) } & & & & 5.376 & & -5.006 \\
\hline & & & & $(0.358)^{* * *}$ & & $(0.419)^{* * *}$ \\
\hline & & & & {$[0.691]^{* * *}$} & & {$[0.820]^{* * *}$} \\
\hline \multirow{3}{*}{ party votes (\%) } & & & & -0.625 & & 0.321 \\
\hline & & & & $(0.0391)^{* * *}$ & & $(0.0482)^{* * *}$ \\
\hline & & & & {$[0.0482]^{* * *}$} & & {$[0.0686]^{* * *}$} \\
\hline \multirow{3}{*}{$\begin{array}{l}\text { Share green party } \\
\text { votes (\%) }\end{array}$} & & & & 0.686 & & 0.940 \\
\hline & & & & $(0.0835)^{* * *}$ & & $(0.0889)^{* * *}$ \\
\hline & & & & {$[0.110]^{* * *}$} & & {$[0.120]^{* * *}$} \\
\hline \multirow[t]{3}{*}{ Constant } & 36.849 & 30.093 & 29.127 & 28.704 & 58.572 & 59.786 \\
\hline & $(0.284)^{* * *}$ & $(0.504)^{* * *}$ & $(0.494)^{* * *}$ & $(0.334)^{* * *}$ & $(0.439)^{* * *}$ & $(0.390)^{* * *}$ \\
\hline & {$[0.761]^{* * *}$} & {$[1.247]^{* * *}$} & {$[0.901]^{* * *}$} & {$[0.528]^{* * *}$} & {$[0.999]^{* * *}$} & {$[0.774]^{* * *}$} \\
\hline$R^{2}$ & 0.067 & 0.187 & 0.496 & 0.743 & 0.515 & 0.653 \\
\hline $\mathrm{N}$ & 1101 & 1101 & 1101 & 1101 & 1101 & 1101 \\
\hline
\end{tabular}

Notes: OLS estimates. All variables are centered (zero mean) except for the distance measure. All variables refer to 2011 , the year of the referendum, except political party shares, which stem from the 2009 federal elections. White-robust standard errors in parentheses, Conley-adjusted standard errors in brackets: ${ }^{*} \mathrm{p}<0.1,{ }^{* *} \mathrm{p}<0.05$, $* * * \mathrm{p}<0.01$.

\subsection{Robustness and extensions}

In Table 6, we alter the baseline model along a number of dimensions. To save space, we restrict the presentation to the primary variables of interest and the more-conservative specification, which includes political controls. Results for the full model and for the case wherein the political controls are excluded, are given in Appendix II (Table A3). 
In the WLS model, wherein we attach proportionately higher weights to municipalities with a larger electorate, the age effects are lower but statistically significant and within the range of the benchmark results (Column 1). The logit (BC) model yields an effect of a one-year increase in average age on the odds of a yes vote of $3.3 \%(2) .{ }^{18}$ This is somewhat larger than the $(0.71 / 36.85=) 2 \%$ effect implied by the OLS reference model at the mean of the distribution of yes votes (Table 5, Column 4). Controlling for turnout hardly affects the estimated age effect (Column 3). This is the expected result given that turnout and average age are conditionally uncorrelated (Table 5, Column 6). Using the gravitybased measure of expected changes in travel times instead of a simple straight-line distance from Stuttgart to capture the expected accessibility changes, has a moderate effect on the age effect (Column 4). The explanatory power of this model is notably lower than that of the model using the straight-line distance measure. Possibly, voters had imperfect information regarding the expected accessibility changes, or distance from Stuttgart 21 affects the voting outcomes through channels other than expected accessibility gains. ${ }^{19}$ The age effect remains similarly unchanged if we allow for a non-linear effect of proximity to Stuttgart by means of 10-km distance bins (Column 5). An examination of the 10-km distance-bin effects reveals an approximately linear distance effect (conditional on other factors), confirming the parametric baseline model (see Figure A5 in Appendix II). Finally, we find qualitatively consistent age effects when using the share of elderly (65 years and older) among the electorate as an alternative age-related explanatory variable.

18 The logit model is identical to the OLS model in Equation (1) except for using $\log (P R C N T Y E S /[1-$ $P R C N T Y E S]$ ) as a dependent variable. To account for the grouped nature of the data, the observations are weighted by the inverse square root of the error term's variance. For a recent application, see Schulz \& Ursprung (2000).

19 For example, voters in such city regions as Freiburg, Heidelberg, Karlsruhe, or Mannheim, which are relatively farther from Stuttgart, may perceive the state capital Stuttgart as a competitor to their own local economies, and therefore be less likely to support a project that would strengthen it. 
Tab. 6. Determinants of opposition to Stuttgart 21: Alternative Models

\begin{tabular}{|c|c|c|c|c|c|c|}
\hline & (1) & (2) & (3) & (4) & (5) & (6) \\
\hline & $\begin{array}{l}\text { Share yes } \\
\text { votes (\%) }\end{array}$ & $\begin{array}{l}\text { Share yes } \\
\text { votes (\%) }\end{array}$ & $\begin{array}{l}\text { Share yes } \\
\text { votes (\%) }\end{array}$ & $\begin{array}{l}\text { Share yes } \\
\text { votes (\%) }\end{array}$ & $\begin{array}{l}\text { Share yes } \\
\text { votes (\%) }\end{array}$ & $\begin{array}{l}\text { Share yes } \\
\text { votes (\%) }\end{array}$ \\
\hline & WLS & $\mathrm{BC}$ & $2 S L S$ & OLS & OLS & OLS \\
\hline Average age (years) & $\begin{array}{l}0.559^{* * *} \\
(0.182)\end{array}$ & $\begin{array}{l}0.0326^{* * *} \\
(0.00539)\end{array}$ & $\begin{array}{l}0.764^{* * *} \\
(0.130)\end{array}$ & $\begin{array}{l}0.678^{* * *} \\
(0.141)\end{array}$ & $\begin{array}{l}0.732^{* * *} \\
(0.134)\end{array}$ & \\
\hline Share age $65<(\%)$ & & & & & & $\begin{array}{l}0.188^{* * *} \\
(0.0625)\end{array}$ \\
\hline $\begin{array}{l}\text { Distance from Stuttgart } \\
(\mathrm{km})\end{array}$ & $\begin{array}{l}0.0704^{* * *} \\
(0.00637)\end{array}$ & $\begin{array}{l}0.00295^{* * *} \\
(0.000193)\end{array}$ & $\begin{array}{l}0.0537^{* * *} \\
(0.0101)\end{array}$ & & & $\begin{array}{l}0.0765^{* * *} \\
(0.00457)\end{array}$ \\
\hline Delta travel time (minutes) & & & & $\begin{array}{l}0.103^{*} \\
(0.0524)\end{array}$ & & \\
\hline Turnout (instrumented) & & & $\begin{array}{l}-0.193^{* *} \\
(0.0758)\end{array}$ & & & \\
\hline Socio-economic controls & Yes & Yes & Yes & Yes & Yes & Yes \\
\hline Political controls & Yes & Yes & Yes & Yes & Yes & Yes \\
\hline S21 distance bins & - & - & - & - & Yes & - \\
\hline $\mathrm{R}^{2}$ & 0.807 & 0.742 & 0.766 & 0.693 & 0.745 & 0.737 \\
\hline $\mathrm{N}$ & 1101 & 1101 & 1101 & 1101 & 1101 & 1101 \\
\hline
\end{tabular}

Notes: Observations in the WLS model are weighted by the electorate. Observations in the BC models are weighted by the inverse square root of the error term's variance (see footnote 22). Delta travel time is the expected average change in travel time to all other municipalities weighted by the share of out-commuters. The instrument in model (9) is the 2009 federal election turnout. Stuttgart 21 distance bins are fixed effects for mutually exclusive 10-km distance bins containing municipalities within 0-5 km, 5-15 km, 15-25 km, etc. White-robust standard errors in parentheses: ${ }^{*} \mathrm{p}<0.1,{ }^{* *} \mathrm{p}<0.05,{ }^{* * *} \mathrm{p}<0.01$. WLS models: standard errors in parentheses: ${ }^{*} \mathrm{p}<0.1,{ }^{* *}$ $\mathrm{p}<0.05, * * * \mathrm{p}<0.01$.

As a further alteration to the baseline model, we have interacted average age with all other covariates in both cases, including and excluding political controls (see Appendix II, Table A5 for the full results). Two effects are particularly interesting in the context of related literature. The baseline models suggest a relatively strong relationship between homeownership rate and support for Stuttgart 21. To the extent that Stuttgart 21 was expected to increase property prices, this empirical relationship can be rationalized with an asset gain or wealth motive as discussed in the literature on the homevoter hypothesis (Ahlfeldt and Maennig, 2015; Dehring et al., 2008; Fischel, 2001a). The positive interaction effect between the homeownership rate and the average age informs this literature in that it is particularly the young homeowners who vote according to such a wealth motive. This is intuitive since younger homeowners are more likely to sell their property over their remaining lifetime. The other interesting effect is the positive interaction between average age and share of male voters. The fact that opposition to Stuttgart 21 among the elderly is driven by male voters is in line with behavioral economics results suggesting that women are more altruistic, in particular if altruism is expensive (Andreoni and Vesterlund, 2001).

In the last set of estimates reported in Table 7, we address the concern that there may be unobserved variables that simultaneously determine average age and attitudes towards Stuttgart 21 for reasons 
unrelated to age. Columns (1) and (2) report the OLS models including county-level controls for the shares of the secondary and tertiary sectors, which are required to meet the orthogonality condition in the 2SLS estimates introduced in the next Columns. The contemporary sectoral shares do not significantly impact the voting decision, which is why we excluded these controls in all previous models. Using historic sector shares and historic shares of children as instruments for average age tends to increase the age effect, regardless of whether we control for turnout (Columns 5 and 6) or not (Columns 3 and 4). All models in Table 7 yield reasonable F-statistics and pass Hansen's J test. Estimates using historic age groups or historic industry shares as exclusive instruments or the change in sector shares from 1961 to 1970 and from 1970 to 1987 are in the appendix (Table A6 in Appendix II). As with the estimates reported here, the age effect tends to increase. Across a range of specifications reported here and in Appendix II, model (4) in Table 7 is the only one where the standard errors increase to the extent that the age effect becomes insignificant.

Some care is warranted with the interpretation of these 2SLS estimates given the large variation across specifications, which suggests a highly local nature of the local average treatment effects (LATE). Yet, a fair conclusion from the positive age effects across a relatively wide range of specifications exploiting distinct sources of identifying variation seems to be that the positive relationship between opposition to Stuttgart 21 and the average age of the electorate is unlikely to be driven by an omitted variable. 
Tab. 7. Determinants of opposition to Stuttgart 21: 2SLS models

\begin{tabular}{|c|c|c|c|c|c|c|}
\hline & (1) & $(2)$ & (3) & $(4)$ & $(5)$ & (6) \\
\hline & $\begin{array}{l}\text { Share yes } \\
\text { votes (\%) }\end{array}$ & $\begin{array}{l}\text { Share yes } \\
\text { votes (\%) }\end{array}$ & $\begin{array}{l}\text { Share yes } \\
\text { votes (\%) }\end{array}$ & $\begin{array}{l}\text { Share yes } \\
\text { votes }(\%)\end{array}$ & $\begin{array}{l}\text { Share yes } \\
\text { votes (\%) }\end{array}$ & $\begin{array}{l}\text { Share yes } \\
\text { votes (\%) }\end{array}$ \\
\hline & OLS & OLS & 2SLS & $2 S L S$ & $2 S L S$ & $2 S L S$ \\
\hline $\begin{array}{l}\text { Average age } \\
\quad \text { (instrumented) }\end{array}$ & $\begin{array}{l}1.082^{* * *} \\
(0.300)\end{array}$ & $\begin{array}{l}0.706^{* * *} \\
(0.183)\end{array}$ & $\begin{array}{l}3.869^{* * *} \\
(1.275)\end{array}$ & $\begin{array}{l}1.125 \\
(0.793)\end{array}$ & $\begin{array}{l}4.026^{* * *} \\
(1.129)\end{array}$ & $\begin{array}{l}2.500^{* * *} \\
(0.942)\end{array}$ \\
\hline $\begin{array}{l}\text { Distance from Stuttgart } \\
\qquad(\mathrm{km})\end{array}$ & $\begin{array}{l}0.108^{* * *} \\
(0.019)\end{array}$ & $\begin{array}{l}0.075^{* * *} \\
(0.013)\end{array}$ & $\begin{array}{l}0.100^{* * *} \\
(0.019)\end{array}$ & $\begin{array}{l}0.075^{* * *} \\
(0.012)\end{array}$ & $\begin{array}{l}0.007 \\
(0.028)\end{array}$ & $\begin{array}{l}0.009 \\
(0.019)\end{array}$ \\
\hline $\begin{array}{l}\text { Share secondary sector } \\
\quad 2011(\%)\end{array}$ & $\begin{array}{l}3.931 \\
(3.450)\end{array}$ & $\begin{array}{l}-0.219 \\
(2.240)\end{array}$ & $\begin{array}{l}2.414 \\
(3.050)\end{array}$ & $\begin{array}{l}-0.287 \\
(2.179)\end{array}$ & $\begin{array}{l}-2.141 \\
(2.723)\end{array}$ & $\begin{array}{l}-1.263 \\
(1.651)\end{array}$ \\
\hline $\begin{array}{l}\text { Share tertiary sector } 2011 \\
\quad(\%)\end{array}$ & $\begin{array}{l}4.195 \\
(3.493)\end{array}$ & $\begin{array}{l}-0.085 \\
(2.269)\end{array}$ & $\begin{array}{l}2.654 \\
(3.096)\end{array}$ & $\begin{array}{l}-0.153 \\
(2.208)\end{array}$ & $\begin{array}{l}-1.958 \\
(2.775)\end{array}$ & $\begin{array}{l}-1.160 \\
(1.682)\end{array}$ \\
\hline Turnout (instrumented) & & & & & $\begin{array}{l}-0.636^{* * *} \\
(0.141)\end{array}$ & $\begin{array}{l}-0.545^{* * *} \\
(0.139)\end{array}$ \\
\hline Socio-economic controls & Yes & Yes & Yes & Yes & Yes & Yes \\
\hline Political controls & - & Yes & - & Yes & - & Yes \\
\hline Industry IV & - & - & Yes & Yes & Yes & Yes \\
\hline Age IV & - & - & Yes & Yes & Yes & Yes \\
\hline Turnout 2009 IV & - & - & - & - & Yes & Yes \\
\hline CDF F Stat & . & . & 18.297 & 15.841 & 16.703 & 12.059 \\
\hline Hansen J P & . & . & 0.176 & 0.149 & 0.411 & 0.120 \\
\hline $\mathrm{R}^{2}$ & 0.527 & 0.750 & 0.393 & 0.747 & 0.373 & 0.713 \\
\hline $\mathrm{N}$ & 1101 & 1101 & 1101 & 1101 & 1101 & 1101 \\
\hline
\end{tabular}

Notes: Political controls are share of conservative party voters, share of green party voters, and an indicator variable for Baden. Socio-economic controls are all other covariates reported in Table 5, but not reported here. Industry IV denotes the shares of the secondary and the tertiary sectors in 1961, 1970, and 1987 (county level). Age IV denotes the shares of population aged 0-5 and 6-15 in 1950 and 1961 (municipality level). Turnout IV is the turnout in the 2009 federal election. Standard errors clustered on counties in all models: ${ }^{*} p<0.1,{ }^{* *} p<0.05,{ }^{* * *}$ $p<0.01$.

\subsection{Counterfactual simulation of the effects of population ageing}

To place the estimated age effects in the Stuttgart 21 referendum in the context of population ageing, we conduct a back-of-the-envelope simulation in the spirit of Poterba (1998). We combine our estimates with a recent population projection to answer the question of how the referendum outcome would differ were it held in the future. We consider twelve combinations of (four) estimated age effects and (three) population projections. When exclusively using the estimated age effect conditional on distance from Stuttgart 21 (Table 5, Column 2), we implicitly assume that all socio-economic and political covariates are endogenous and will change as the population ages. In contrast, when using our preferred upper and lower bound estimates (Table 5, Columns 3 and 4), we let the population age, ceteris paribus. Our fourth and most conservative estimate is from the WLS model in Table 6, Column (1). For population ageing, we refer to a baseline, an optimistic, and a pessimistic scenario, which we all take from an official report published by the federal statistical office (Statistisches 
Bundesamt, 2009). ${ }^{20}$ According to the baseline scenario, the average age of the German population will increase by seven years from 43.4 in 2011 to 50.4 years in $2060 . .^{21}$ The average age of the adult population (electorate), on which our analysis is based, will increase from 50.6 years in 2011 to 57.1 years in 2060.22

Our counterfactual simulations of the effect of population ageing on the share of yes votes in the Stuttgart 21 referendum are summarized in Figure 5. We start from the 2011 share of yes votes of 41.1 percent. For each subsequent year, we increase this share by the product of the expected change in the average age of the adult population relative to 2011 and the estimate of the marginal effect of age on the share of yes votes in the Stuttgart 21 referendum. ${ }^{23}$ Common to all scenarios, the counterfactual share of yes votes increases with time, with the rate of increase decreasing from the 2030s onwards. Holding other factors constant, the share of yes votes in the reference scenarios (thick black lines) will increase by 2.8 (age effects based on Column (4) of Table 5) to 4.7 (Column (3) of Table 5) percentage points over 20 years, a sizable magnitude given that referenda are often relatively narrowly decided (Dehring et al., 2008). Despite the clear majority vote in the Stuttgart 21 referendum, we find that the effect of population ageing after four decades would be large enough to lead to the rejection of the project in three out of the twelve scenarios considered. Combining the most pessimistic (rapid ageing) population projection with the largest estimated age effect (only controlling for distance from Stuttgart 21), the implication is that the project would have been rejected as early as in 2037. Taking into account the margins of statistical uncertainty, a rejection cannot be ruled out at conventional confidence levels (95\%) from as early as 2030s onwards.

Given the strong partial equilibrium assumptions made, the numbers presented in this section need to be interpreted with care. The main takeaway is that our estimated age effects and the expected

20 In notations of the federal statistical office, we make use of the projections variant1-w1 (baseline), variant2w3 (optimistic), and variant 6-23 (pessimistic).

21 The variant1-w1 scenario (middle population, lower limit) is based on the assumptions of (i) an increase in life expectancy of 8 years for newly born males and 7 years for females by 2060, (ii) a roughly constant birth rate of 1.4 children/woman, and (iii) an annual net migration of 100,000 persons starting in 2014.

22 Since the federal statistical office publishes the population projection by one-year age bins, the computation of the average age of the adult population (18 years and older) is straightforward. See footnote 18.

${ }^{23}$ For any given year $t$, the counterfactual voting outcome is $\widehat{V}_{t}=V_{2011}+\hat{\beta}\left(\overline{A G E}_{t}-\overline{A G E}_{2011}\right)$, were $V_{2011}$ is the percent of yes votes in the 2011 referendum, $\hat{\beta}$ is our estimate of the age effect, $\bar{A} G E_{2011}$ is the average age of the adult population in 2011, and $\overline{A G E}_{t}$ is the respective projection for year $t$. 
population ageing together appear to be large enough to be quantitatively meaningful. Population ageing, thus, could realistically influence direct democracy outcomes in the foreseeable future.

\section{Fig. 5. Counterfactual Stuttgart 21 voting outcomes}

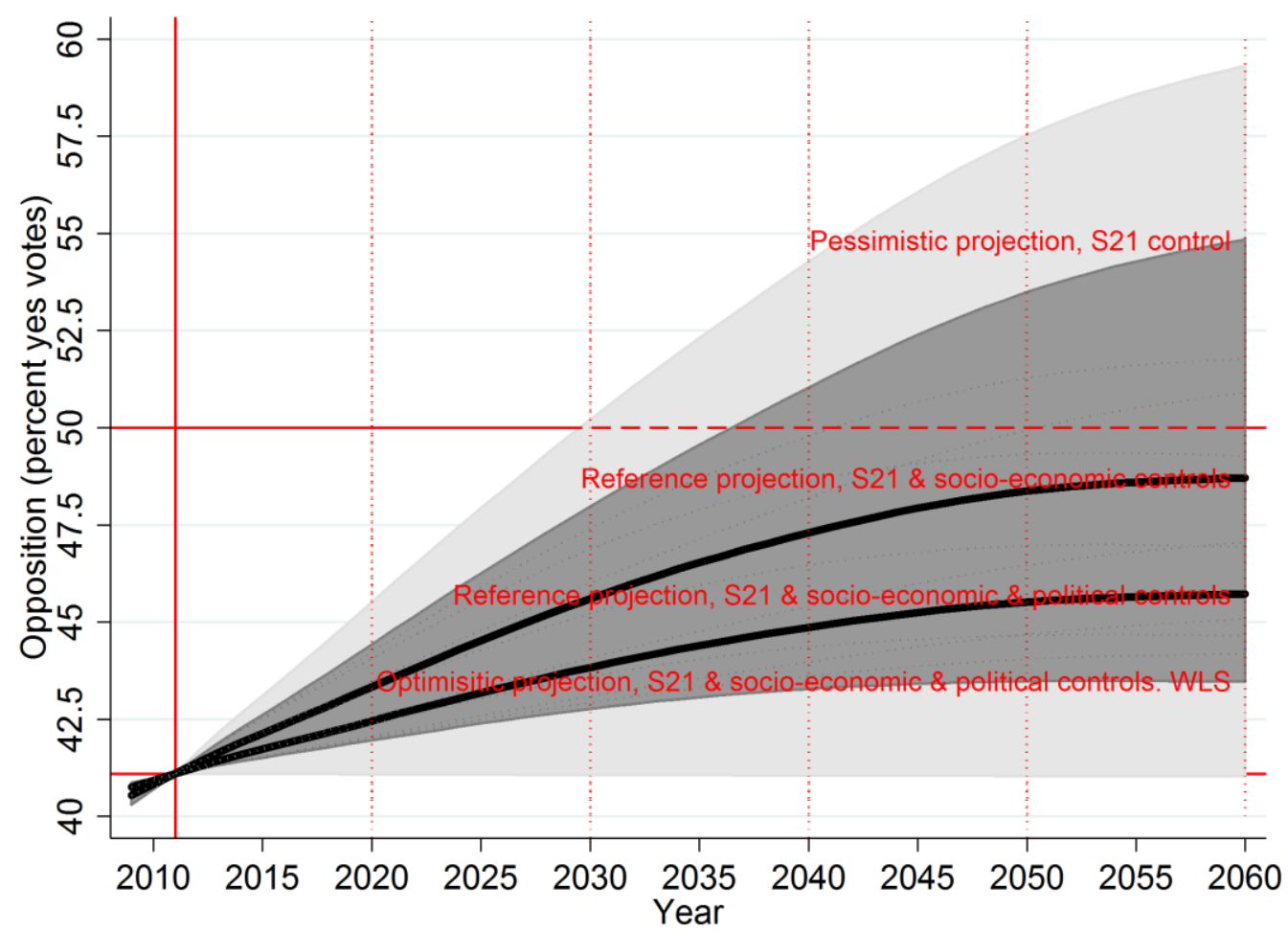

Notes: Own illustration based on estimates from Table 5, Columns (2-4) and Table 6, Column (1), and the scenarios V1-W1 (reference), V3-W2 (optimistic), and V6-W1 (pessimistic) published in the $12^{\text {th }}$ coordinated population projection by the German Federal Statistical Office (Statistisches Bundesamt, 2009). The dark shaded area is the envelope of all counterfactual voting outcomes for different combinations of estimated age effects and population projections (the light dotted rays). The light shaded area is the envelope of all $95 \%$ confidence intervals.

\section{Conclusion}

This paper analyzes the effect of voter age on voting decisions in public polls, such as initiatives and referenda, to understand the implications of population ageing for direct democracy. To this end, we provide the first quantitative review of the literature and a case study of the Stuttgart 21 referendum on one of the largest infrastructure projects in Germany. We find that across a variety of topics such as environmental legislation, political integration, culture, or sports facilities, existing referendum analyses do not suggest age to be an unambiguous determinant of voting decisions, and thus, no obvious potential for an inter-generational conflict. In contrast, on questions related to spending on public schools or green energy reforms, where an intergenerational difference in net present value is particularly evident, the literature reveals an overwhelming tendency for the elderly to vote in generational self-interest. Our results from the case study on Stuttgart 21 are in line with this finding. 
The major rail infrastructure project analyzed will cause significant disruptions to transit services during the at-least 10 -year construction period before benefits will eventually materialize, implying relatively lower net-benefits for older generations. In line with these generational differences in expected net present value, we find that the average age of the electorate significantly increases the opposition to the project. Taking the projected population ageing in Germany as a benchmark, the estimated age effects in the referendum are large enough to realistically change referendum outcomes in the future. Our results raise the question of whether, as population ageing progresses, decisions on projects whose benefits materialize only in the long run, would be better based on social cost benefit analyses than on referenda.

\section{Literature}

Abel, A. B. (2001). Will Bequests Attenuate the Predicted Meltdown in Stock Prices When Baby Boomers Retire? Review of Economics and Statistics, 83(4), 589-595.

Acemoglu, D., and Johnson, S. (2007). Disease and Development: The Effect of Life Expectancy on Economic Growth. Journal of Political Economy, 115(6), 925-985.

Ahlfeldt, G. M., and Maennig, W. (2015). Homevoters vs. leasevoters: A spatial analysis of airport effects. Journal of Urban Economics, 87(0), 85-99.

Ahlfeldt, G. M., Redding, S. J., Sturm, D. M., and Wolf, N. (2015). The Economics of Density: Evidence from the Berlin Wall. Econometrica, 83(6), 2127-2189.

Andreoni, J., and Vesterlund, L. (2001). Which is the Fair Sex? Gender Differences in Altruism. The Quarterly Journal of Economics, 116(1), 293-312.

Angrist, J. D., and Pischke, J.-S. (2009). Mostly Harmless Econometrics: An Empiricist's Companion. Princeton, New Jersey: Princeton University Press.

Aristotle. (1975). The Nicomachean Ethics. Translated by H. Rackham. Loeb Classical Library 73. Cambridge, MA: Harvard University Press.

Baum-Snow, N. (2007). Did Highways Cause Suburbanization? The Quarterly Journal of Economics, 122(2), 775-805.

Bernheim, B. D., and Ray, D. (1987). Economic Growth with Intergenerational Altruism. The Review of Economic Studies, 54(2), 227-243.

Breyer, F., and Stolte, K. (2001). Demographic change, endogenous labor supply and the political feasibility of pension reform. Journal of Population Economics, 14(3), 409-424.

Brunner, E., and Balsdon, E. (2004). Intergenerational conflict and the political economy of school spending. Journal of Urban Economics, 56(2), 369-388.

Brunner, E., Ross, S. L., and Washington, E. (2011). Economics and policy preferences: Causal evidence of the impact of economic conditions on support for redistribution and other ballot proposals. The Review of Economics and Statistics, 93(3), 888-906.

Brunner, E., Sonstelie, J., and Thayer, M. (2001). Capitalization and the Voucher: An Analysis of Precinct Returns from California's Proposition 174. Journal of Urban Economics, 50(3), 517536.

Coates, D., and Humphreys, B. R. (2006). Proximity benefits and voting on stadium and arena subsidies. [Article]. Journal of Urban Economics, 59(2), 285-299.

Conley, T. G. (1999). GMM estimation with cross sectional dependence. Journal of Econometrics, 92(1), 1-45.

Deacon, R., and Shapiro, P. (1975). Private Preference for Collective Goods Revealed Through Voting on Referenda. The American Economic Review, 65(5), 943-955.

Dehring, C. A., Depken, C. A., and Ward, M. R. (2008). A direct test of the homevoter hypothesis. Journal of Urban Economics, 64(1), 155-170. 
Demange, G., and Laroque, G. (1999). Social Security and Demographic Shocks. Econometrica, 67(3), 527-542.

Department for Transport. (2014). Transport Analysis Guidance (TAG) Unit A1.1 Cost-Benefit Analysis. Retrieved from https://www.gov.uk/transport-analysis-guidance-webtag

Duranton, G., and Turner, M. A. (2012). Urban Growth and Transportation. The Review of Economic Studies, 79(4), 1407-1440.

Eckel, C. C., and Füllbrunn, S. C. (2015). Thar SHE Blows? Gender, Competition, and Bubbles in Experimental Asset Markets. American Economic Review, 105(2), 906-920.

Feigenbaum, S., Karoly, L., and Levy, D. (1988). When votes are words not deeds: Some evidence from the Nuclear Freeze Referendum. Public Choice, 58(3), 201-216.

Feinerman, E., Finkelshtain, I., and Kan, I. (2004). On A Political Solution to the NIMBY Conflict. American Economic Review, 94(1), 369-381.

Feld, L. P., and Matsusaka, J. G. (2003). Budget referendums and government spending: evidence from Swiss cantons. Journal of Public Economics, 87(12), 2703-2724.

Fernandez, R., and Rodrik, D. (1991). Resistance to Reform: Status Quo Bias in the Presence of Individual-Specific Uncertainty. American Economic Review, 81(5), 1146-1155.

Fischel, W. A. (1979). Determinants of voting on environmental quality: A study of a New Hampshire pulp mill referendum. Journal of Environmental Economics and Management, 6(2), 107-118.

Fischel, W. A. (2001a). The Homevoter Hypothesis. Cambridge, MA: Harvard University Press.

Fischel, W. A. (2001b). Why Are There NIMBYs? Land Economics, 77(1), 144-152.

Frey, B. S., Oberholzer-Gee, F., and Eichenberger, R. (1996). The old lady visits your backyard: A tale of morals and markets. Journal of Political Economy, 104(6), 1297.

Gradstein, M., and Kaganovich, M. (2004). Aging population and education finance. Journal of Public Economics, 88(12), 2469-2485.

Harris, A. R., Evans, W. N., and Schwab, R. M. (2001). Education spending in an aging America. Journal of Public Economics, 81(3), 449-472.

Holtz-Eakin, D., Lovely, M. E., and Tosun, M. S. (2004). Generational conflict, fiscal policy, and economic growth. Journal of Macroeconomics, 26(1), 1-23.

Hunter, J. E., and Schmidt, F. L. (1990). Methods of Meta-Analysis: Correcting Error and Bias in Research Findings. Newbury Park: Sage Publications.

Kahn, M. E., and Matsusaka, J. G. (1997). Demand for Environmental Goods: Evidence from Voting Patterns on California Initiatives. The Journal of Law and Economics, 40(1), 137-173.

Kahneman, D., Knetsch, J. L., and Thaler, R. H. (1991). Anomalies: The Endowment Effect, Loss Aversion, and Status Quo Bias. Journal of Economic Perspectives, 5(1), 193-206.

Krueger, D., and Ludwig, A. (2007). On the consequences of demographic change for rates of returns to capital, and the distribution of wealth and welfare. Journal of Monetary Economics, 54(1), 49-87.

Kulick, M. S. (2011). Absturz der Volksparteien. Eine Analyse der loyalen und ehemaligen Wählerschaft von CDU und SPD im Vergleich. In O. Niedermayer (Ed.), Die Parteien nach der Bundestagswahl 2009. Wiesbaden: VS Verlag für Sozialwissenschaften.

Kurbjuweit, D. (2010). Der Wutbürger. Der Spiegel, 41, October 11, 26-27.

Ladd, H. F., and Murray, S. E. (2001). Intergenerational conflict reconsidered: county demographic structure and the demand for public education. Economics of Education Review, 20(4), 343357.

Mather, M., Mazar, N., Gorlick, M. A., Lighthall, N. R., Burgeno, J., Schoeke, A., and Ariely, D. (2012). Risk preferences and aging: The "certainty effect" in older adults' decision making. Psychology and Aging, 27(4), 801-816.

Matsusaka, J. G. (2004). For the Many or the Few: The Initiative, Public Policy, and the American Democracy. Chicago: University of Chicago Press.

Matsusaka, J. G. (2005). Direct Democracy Works. Journal of Economic Perspectives, 19(2), 185-206.

Melo, P. C., Graham, D. J., and Brage-Ardao, R. (2013). The productivity of transport infrastructure investment: A meta-analysis of empirical evidence. Regional Science and Urban Economics, 43(5), 695-706.

Nitsch, V. (2005). Zipf zipped. Journal of Urban Economics, 57(1), 86-100. 
Osborne, M. J., and Turner, M. A. (2010). Cost Benefit Analysis versus Referenda. Journal of Political Economy, 118(11), 156-187.

Oyserman, D., Coon, H. M., and Kemmelmeier, M. (2002). Rethinking Individualism and Collectivism: Evaluation of Theoretical Assumptions and Meta-Analyses. Psychological Bulletin, 128(1), 372.

Poterba, J. M. (1998). Demographic Change, Intergenerational Linkages, and Public Education. The American Economic Review Papers and Proceedings, 88(2), 315-320.

Poterba, J. M. (2001). Demographic Structure and Asset Returns. The Review of Economics and Statistics, 83(4), 565-584.

Rapoport, H., and Vidal, J.-P. (2007). Economic growth and endogenous intergenerational altruism. Journal of Public Economics, 91(7-8), 1231-1246.

Richman, H. A., and Stagner, M. W. (1986). Children: Treasured Resource of Forgotten Minority? In A. Pifer and L. Bronte (Eds.), Our Aging Society: Paradox and Promise (pp. 161-179). New York: Norton.

Rubinfeld, D. L. (1977). Voting in a Local School Election: A Micro Analysis. The Review of Economics and Statistics, 59(1), 30-42.

Schulze, G. G., and Ursprung, H. W. (2000). La donna e mobile -- or is she? Voter preferences and public support for the performing arts. Public Choice, 102(1/2), 131-149.

SMA und Partner AG. (2010). Stuttgart 21 und Kopfbahnhof 21: Vergleichende Analyse der Reisezeiten. Zurich.

Stanley, T. D. (2001). Wheat from Chaff: Meta-analysis as Quantitative Literature Review. Journal of Economic Perspectives, 15(3), 131-150.

Statistisches Bundesamt. (2009). Bevölkerung Deutschlands bis 2060 12. koordinierte Bevölkerungsvorausberechung. Wiesbaden.

Stuckenbrock, U. (2013). Das Projekt "Stuttgart 21" im zeitlichen Überblick. In F. Brettschneider and W. Schuster (Eds.), Stuttgart 21 Ein Großprojekt zwischen Protest und Akzeptanz (pp. 15-76). Wiesbaden: Springer VS.

Thalmann, P. (2004). The Public Acceptance of Green Taxes: 2 Million Voters Express Their Opinion. Public Choice, 119(1-2), 179-217.

The World Bank. (2015). World development indicators. Washington, D.C.: The World Bank.

Triandis, H. C. (1995). Individualism \& collectivism. New directions in social psychology. Boulder, CO, US: Westview Press.

United Nations. (2013). World Population Ageing. New York: United Nations.

Verkehrswissenschaftliches Institut Stuttgart, and Intraplan Consult. (2006). Nutzen-KostenUntersuchung ÖPNV-Maßnahmen Stuttgart 21. Stuttgart: Ministry of the interior, BadenWürtemberg.

Vlachos, J. (2004). Who wants political integration?: Evidence from the Swedish EU-membership referendum. Journal of Public Economics, 88(7-8), 1589-1604.

Wagschal, U. (2013). Die Volksabstimmung zu Stuttgart 21 - ein direktdemokratisches Lehrstück? In U. Wagschal, U. Eith and M. Wehner (Eds.), Der historische Machtwechsel: Grün-rot in BadenWürtemberg (pp. 181-205). Berlin: Nomos.

Winkelmann, U. (2013). Berufspendler in Baden-Württemberg. Statistisches Monatsheft BadenWürttemberg, November 2013, 25-29. 


\section{Appendix I:}

\section{Après nous le déluge? Direct democracy and intergenerational conflicts in aging societies}

Version: January 2016

\section{Introduction}

This web appendix complements the quantitative literature review in the main paper (Section 2). Table A1 presents additional information on the studies considered but not reported in Table 1 owing to space constraints. In addition, we present a stylized representation of the main finding and the encoded attitudes for all referenda analyzed. After Table A1, we provide full bibliographic details of the studies reviewed.

* London School of Economics and Political Sciences (LSE) and Centre for Economic Policy Research (CEPR), Houghton Street, London WC2A 2AE, g.ahlfeldt@lse.ac.uk, www.ahlfeldt.com

- University of Hamburg, Department of Economics, Chair for Economic Policy, Von-Melle-Park 5, 20146 Hamburg, wolfgang.maennig@wiso.uni-hamburg.de

- University of Hamburg, Department of Economics, Chair for Economic Policy, Von-Melle-Park 5, 20146 Hamburg, malte.steenbeck@wiso.uni-hamburg.de 


\section{Appendix II:}

\section{Après nous le déluge? Direct democracy and intergenerational conflicts in aging societies}

Version: January 2016

\section{Introduction}

This web appendix complements the Stuttgart 21 case study results reported in the main paper, by providing additional information-robustness checks and auxiliary results. Although it replicates some text from the main paper for better clarity, it is not designed to stand alone or replace the existing content.

\section{Expected travel time changes}

We use two elements to construct our measure of the expected travel time changes that should result from Stuttgart 21 for each municipality. First, we use a matrix of bilateral commuting flows between the municipalities in Baden-Württemberg, which was provided by their Statistical Office. Second, we use a matrix of expected travel time changes between all municipalities, which needs to be approximated as it does not exist. The most detailed information on how Stuttgart 21 will impact rail travel times in Baden-Württemberg is a matrix of the expected travel time changes between 29 mainline stations reported in a commissioned study by SMA and Partner AG (2010). ${ }^{1}$ To approximate the expected travel time changes between all municipalities, we proceed as fol-

- London School of Economics and Political Sciences (LSE) and Centre for Economic Policy Research (CEPR), Houghton Street, London WC2A 2AE, g.ahlfeldt@lse.ac.uk, www.ahlfeldt.com

- University of Hamburg, Department of Economics, Chair for Economic Policy, Von-Melle-Park 5, 20146 Hamburg, wolfgang.maennig@wiso.uni-hamburg.de

- University of Hamburg, Department of Economics, Chair for Economic Policy, Von-Melle-Park 5, 20146 Hamburg, malte.steenbeck@wiso.uni-hamburg.de

1 This matrix incorporates several smaller complementary rail projects, whose realization does not necessarily depend on Stuttgart 21. 
lows. First, we assign all municipalities to one of the 29 mainline stations covered in the study, based on their geographic proximity. For their assigned hinterlands, each of these 29 stations typically represents the nearest higher-order rail node through which regional or national trains are directed. Second, for each combination of the 29 stations, we create groups of municipality pairs, which share the same station-to-station route. ${ }^{2}$ Third, assuming that travel times to a station within the hinterlands remain unchanged, we assign the expected travel time change of a given station pair to all pairs of municipalities assigned to it.

To compute the expected travel time change for a given municipality, we take the average of the expected travel time changes to all other municipalities, weighted by their respective shares of out-commuting. To impute commuting shares for several missing relations in the data, we use an estimated commuting decay function of the form:

$$
w_{i j}=\exp \left(-\tau \times d_{i j}\right)
$$

where $w_{i j}$ is a spatial weight in bilateral commuting probabilities, with the share of commuters commuting from municipalities $i$ to $j$ being $w_{i j} / \sum_{j} w_{i j} ; \tau$ is a commuting decay parameter; and $d_{i j}$ is the distance between $i$ and $j$. Our estimate of $\tau=0.064$ is obtained from fitting a negative exponential distance function into the cumulative density function of observable commuting distances. This estimated decay is consistent with recent estimates based on German commuting data (Ahlfeldt et al., 2015). ${ }^{3}$

In Figure A1, we illustrate the expected average travel time change along with the 29 mainline stations and their hinterlands.

2 One of the stations (Bad Cannstad) remains unconsidered because it is within the boundaries of Stuttgart. Therefore, it has no hinterland according to our definition.

3 Ahlfeldt et al. (2015), in their preferred models, estimate decay parameters in the range 0.07-0.077 in terms of travel time. The difference between our estimates and theirs implies an average speed of commuting in our study area of 49.9-54.9 km/h, which is reasonable for an area with relatively low density and well-developed transport infrastructure. 
Fig. A1. Expected average travel time change

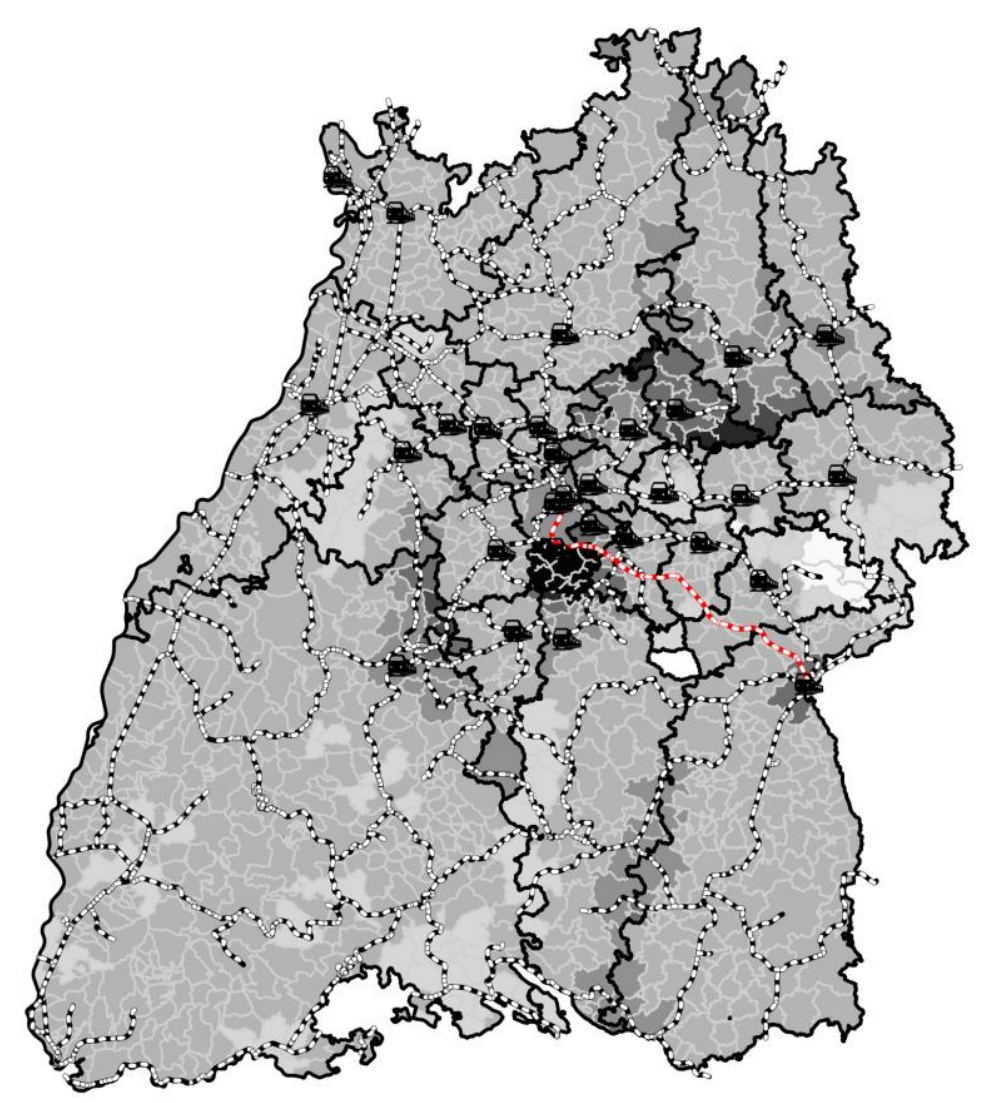

$\begin{array}{lllllll}0 & 15 & 30 & 45 & 60 & 75 & 90 \\ \mathbf{k m}\end{array}$

Travel times: Projected change (weighted)

more than 10 min shorter

$8 \mathrm{~min}-10 \mathrm{~min}$ shorter

6 min - 8 min shorter

4 min -6 min shorter

2 min - 4 min shorter

0 min - 2 min shorter

0 min - 5 min longer

$\square$ more than 5 min longer

- Stations with data on travel times

$\square$ Catchment areas

$\ldots$ HSR Wendlingen - Ulm

$\ldots$ Existing rail network

Notes: The expected average travel time change is the average change in the travel time from one municipality to all other municipalities, weighted by their respective shares of out-commuting. Own illustration based on 29 x $29=841$ station pairs' travel time changes computed by SMA and Partner AG (2010). Commuting shares are computed based on the data provided by the Statistical Office of Baden-Württemberg.

\section{Correlations between yes votes, age, and covariates}

\subsection{Unconditional correlations}

As discussed in Section 3.5 of the main paper, the estimated effect of our measure of average age on the share of yes votes in the Stuttgart 21 referendum is sensitive to the inclusion of covariates, as expected. The obvious reason is that several covariates are correlated with average age and the referendum outcome. The correlations between the covariates and the referendum outcome as well as the average age of the electorate are presented in Figures A2 and A3. The correlations appear generally stronger with the referendum outcome than with the average age. 
Fig. A2. Unconditional correlations between opposition to Stuttgart 21 and covariates
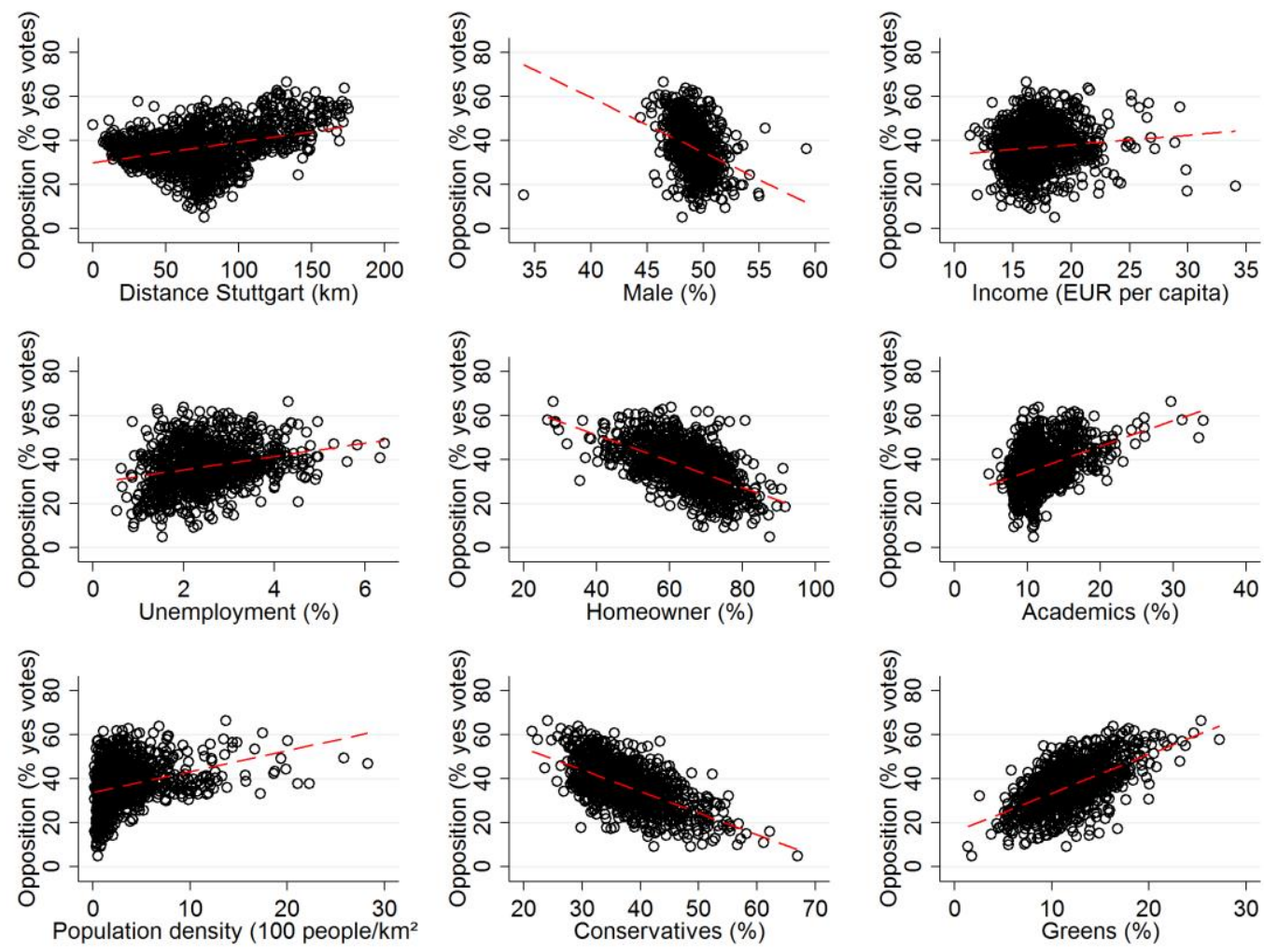

Notes: All panels illustrate raw correlations.

Fig. A3. Unconditional correlations between average age and covariates
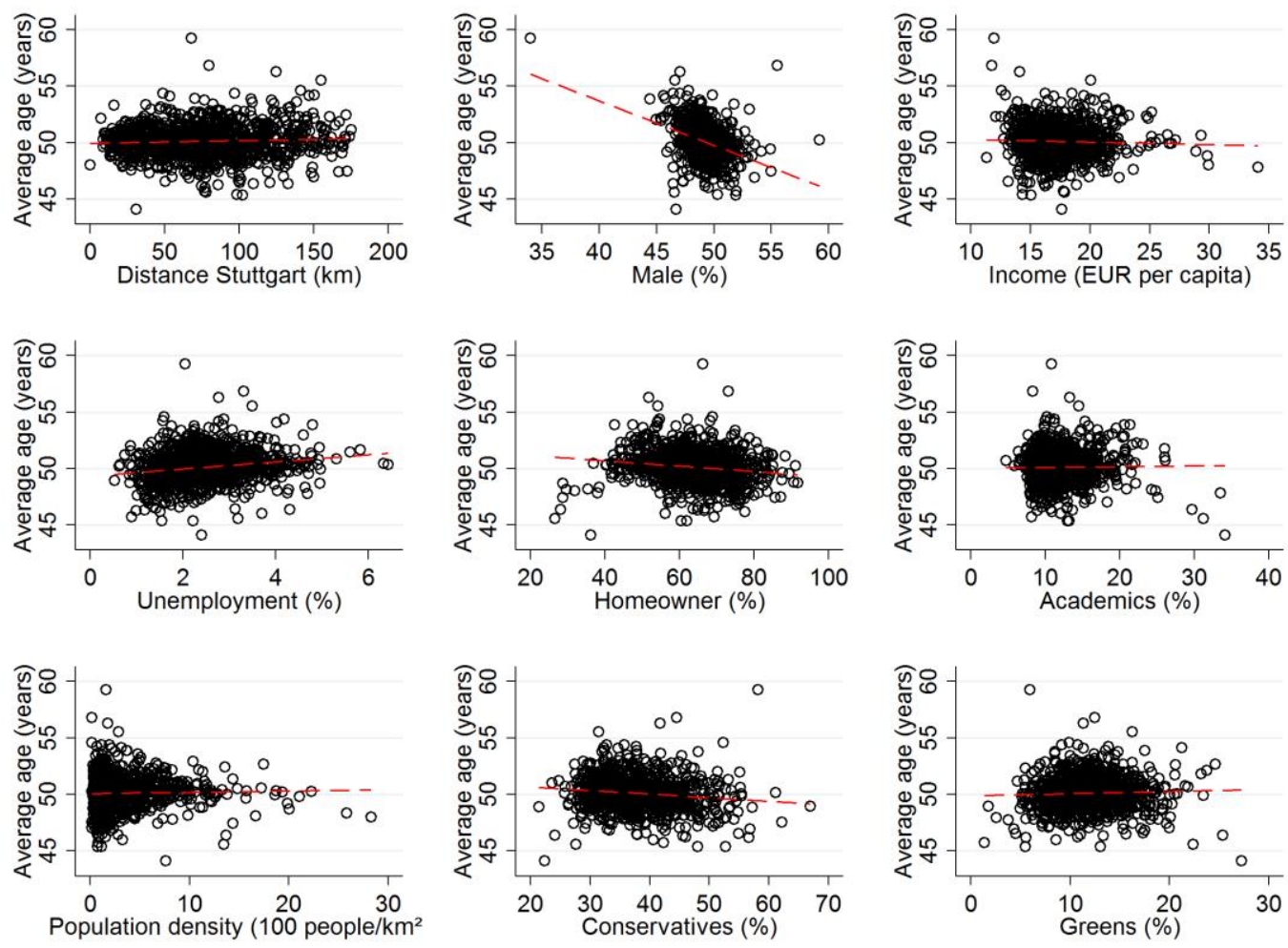

Notes: All panels illustrate raw correlations. 


\subsection{Average age vs. share of yes votes: Conditional correlation control- ling for political party affiliation}

As discussed in Section 3.2 in the main paper, political party shares from past elections and the regional dummy for Baden may be "bad controls" (Angrist and Pischke, 2009). Figure A4 complements Figure 4 in the main paper by showing the correlation between the share of yes votes and the average age controlling for socio-economic characteristics and political variables.

The scatter plot looks remarkably similar to the right panel in Figure 4 in the main paper. In particular, the outlying large cities in the left panel of Figure 4 are close to the linear fit. Consistent with Table 5 in the main paper, the slope coefficient is smaller in Figure A4 than in Figure 4.

Fig. A4. Conditional correlation controlling socio-economic and political variables

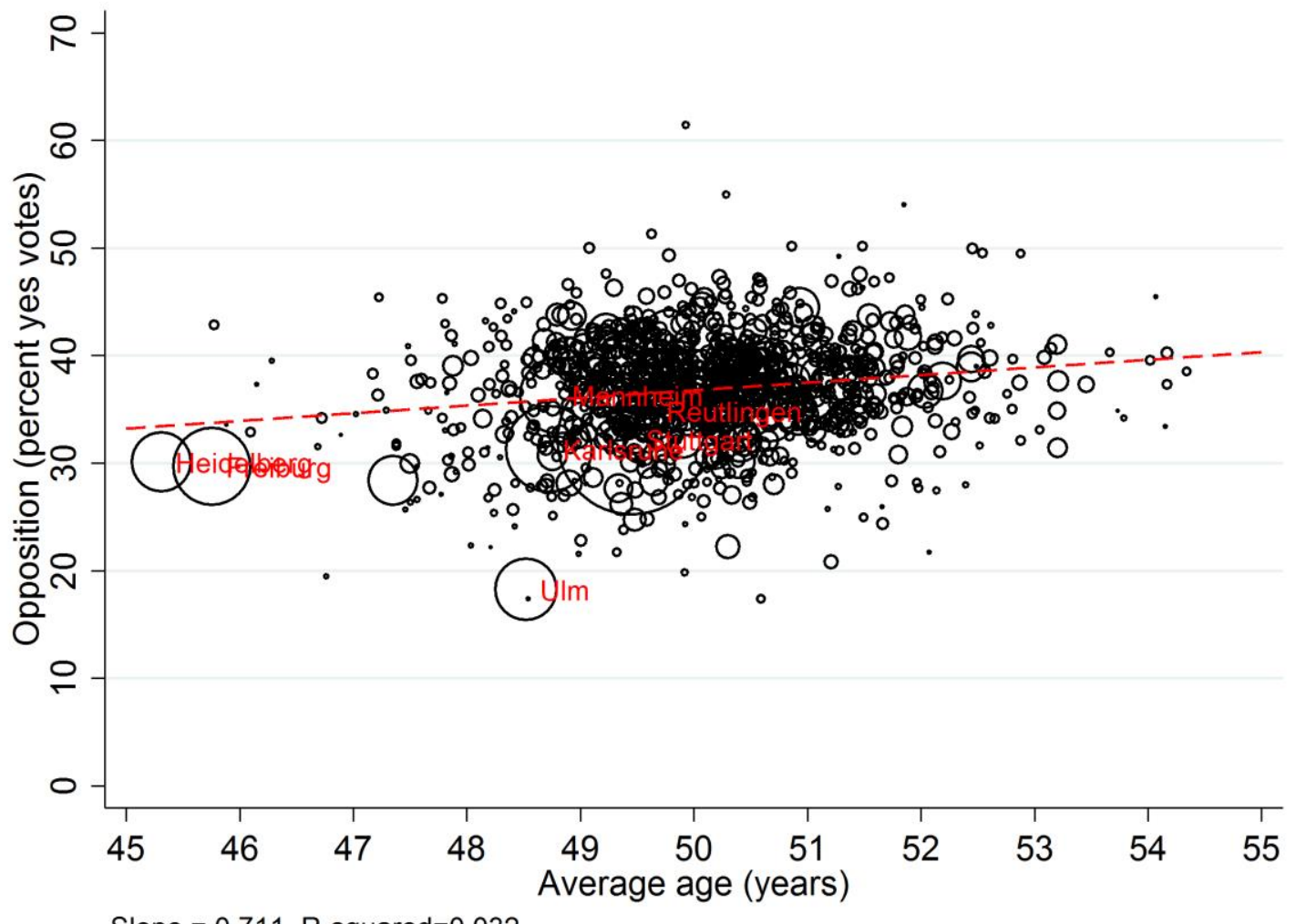

Notes: Average age refers to the adult population (the electorate). The conditional correlation is based on the residuals of a regression of the share of yes votes against all covariates except age, and that of age against the same covariates. The mean share of yes votes and the mean age are added to the respective residuals. The covariates include the share of male voters, share of degree holders, income, unemployment, homeownership, distance to Stuttgart 21, share of Green party votes in the 2009 federal elections, share of conservative party votes in the same elections, and an indicator variable denoting Baden. Several outliers in terms of age are not displayed to improve the presentation. The dashed lines are linear fits into all observations (including outliers). The marker size is proportional to the absolute number of votes. The largest cities are labeled. 


\section{Determinants of political party affiliation}

In the main paper, we find that controlling for party affiliation (conservatives and greens) and region (Baden vs. Württemberg) reduces the age effect by about one-third (Table 5, columns 3 and 4). In Table A1 below, we experiment by either adding party controls or the regional dummy. In each case, the age effect is reduced by about one-sixth compared to the model excluding political controls (Table 5, columns 1-2, column 3 is included for comparison only). In columns (4-6), we regress the political controls against the other covariates. We find a significant conditional correlation between average age and conservative vote shares, but no significant effect of age on the share of greens votes. The partial correlation between the Baden dummy and the average age is statistically significant.

Tab A1. Political variables

\begin{tabular}{lcccccc}
\hline & $(1)$ & $(2)$ & $(3)$ & $(4)$ & $(5)$ & $(6)$ \\
\cline { 2 - 7 } & Share yes & Share yes & Share yes & Conserva- & Greens (\%) & Baden \\
& votes (\%) & votes (\%) & votes (\%) & tives (\%) & & $($ dummy) \\
\hline Average age (years) & $0.965^{* * *}$ & $0.904^{* * *}$ & $0.711^{* * *}$ & $-0.282^{* *}$ & 0.003 & $0.052^{* * *}$ \\
& $(0.136)$ & $(0.188)$ & $(0.131)$ & $(0.140)$ & $(0.0740)$ & $(0.0104)$ \\
Distance from Stuttgart & $0.108^{* * *}$ & $0.076^{* * *}$ & $0.076^{* * *}$ & $0.012^{* *}$ & $0.009^{* * *}$ & $0.005^{* * *}$ \\
$(\mathrm{~km})$ & $(0.00444)$ & $(0.00649)$ & $(0.00457)$ & $(0.00485)$ & $(0.00269)$ & $(0.000344)$ \\
Male (\%) & 0.122 & -0.016 & 0.209 & 0.235 & -0.108 & -0.015 \\
& $(0.187)$ & $(0.314)$ & $(0.161)$ & $(0.272)$ & $(0.107)$ & $(0.0163)$ \\
Per capita income (EUR) & $-0.215^{* * *}$ & 0.100 & $-0.246^{* * *}$ & $-0.342^{* * *}$ & $0.191^{* * *}$ & 0.002 \\
& $(0.0788)$ & $(0.105)$ & $(0.0735)$ & $(0.0962)$ & $(0.0467)$ & $(0.00616)$ \\
Unemployment rate (\%) & -0.217 & $0.875^{* * *}$ & 0.315 & $-1.524^{* * *}$ & $-0.556^{* * *}$ & $-0.041^{*}$ \\
& $(0.277)$ & $(0.321)$ & $(0.254)$ & $(0.258)$ & $(0.128)$ & $(0.0213)$ \\
Homeownership rate (\%) & $-0.189^{* * *}$ & $-0.240^{* * *}$ & $-0.112^{* * *}$ & $0.093^{* * *}$ & $-0.098^{* * *}$ & $-0.011^{* * *}$ \\
& $(0.0302)$ & $(0.0382)$ & $(0.0279)$ & $(0.0308)$ & $(0.0144)$ & $(0.00219)$ \\
Degree share (\%) & $0.225^{* * *}$ & $0.721^{* * *}$ & $0.258^{* * *}$ & $-0.355^{* * *}$ & $0.358^{* * *}$ & $-0.018^{* * *}$ \\
& $(0.0634)$ & $(0.0767)$ & $(0.0553)$ & $(0.0543)$ & $(0.0323)$ & $(0.00532)$ \\
Population density (100 & $0.262^{* * *}$ & $0.337^{* * *}$ & $0.245^{* * *}$ & $-0.128^{* *}$ & 0.015 & 0.005 \\
residents/km $\left.{ }^{2}\right)$ & $(0.0658)$ & $(0.0765)$ & $(0.0596)$ & $(0.0523)$ & $(0.0348)$ & $(0.00527)$ \\
Share of conservative party & $-0.728^{* * *}$ & & $-0.625^{* * *}$ & & & \\
votes (\%) & $(0.0410)$ & & $(0.0391)$ & & & \\
Share of green party votes & $0.408^{* * *}$ & & $0.686^{* * *}$ & & & \\
(\%) & $(0.0867)$ & & $(0.0835)$ & & & \\
Baden (dummy) & & $5.079^{* * *}$ & $5.376^{* * *}$ & & & \\
& & $(0.475)$ & $(0.358)$ & & & \\
Constant & $28.752^{* * *}$ & $28.820^{* * *}$ & $28.704^{* * *}$ & $36.524^{* * *}$ & $11.202^{* * *}$ & $0.060^{* *}$ \\
& $(0.357)$ & $(0.490)$ & $(0.334)$ & $(0.373)$ & $(0.202)$ & $(0.0293)$ \\
\hline $\mathrm{R}^{2}$ & 0.691 & 0.546 & 0.743 & 0.318 & 0.399 & 0.263 \\
$\mathrm{~N}$ & 1101 & 1101 & 1101 & 1101 & 1101 & 1101 \\
\hline
\end{tabular}

Notes: Average age refers to the adult population (the electorate). All variables are centered (zero mean) except for the distance measure. All variables refer to 2011, the year of the referendum, except political party shares, which stem from the 2009 federal elections. Degree share is approximated at the county level for municipalities with less than 10,000 residents. Robust standard errors are denoted in parentheses. ${ }^{*} \mathrm{p}<0.1,{ }^{* *} \mathrm{p}<$ $0.05, * * * \mathrm{p}<0.01$ 


\section{Turnout models}

Table A2 complements Tables 5 and 6 in the main paper by providing additional turnout models.

We experiment with excluding covariates and using a different proximity to Stuttgart 21 measures. We find that once we control for socio-economic attributes, the average age of the electorate has no significant impact on the turnout. The only exception is the model where we combine the travel time-based accessibility measure with potentially endogenous political controls.

Tab A2. Alternative turnout models

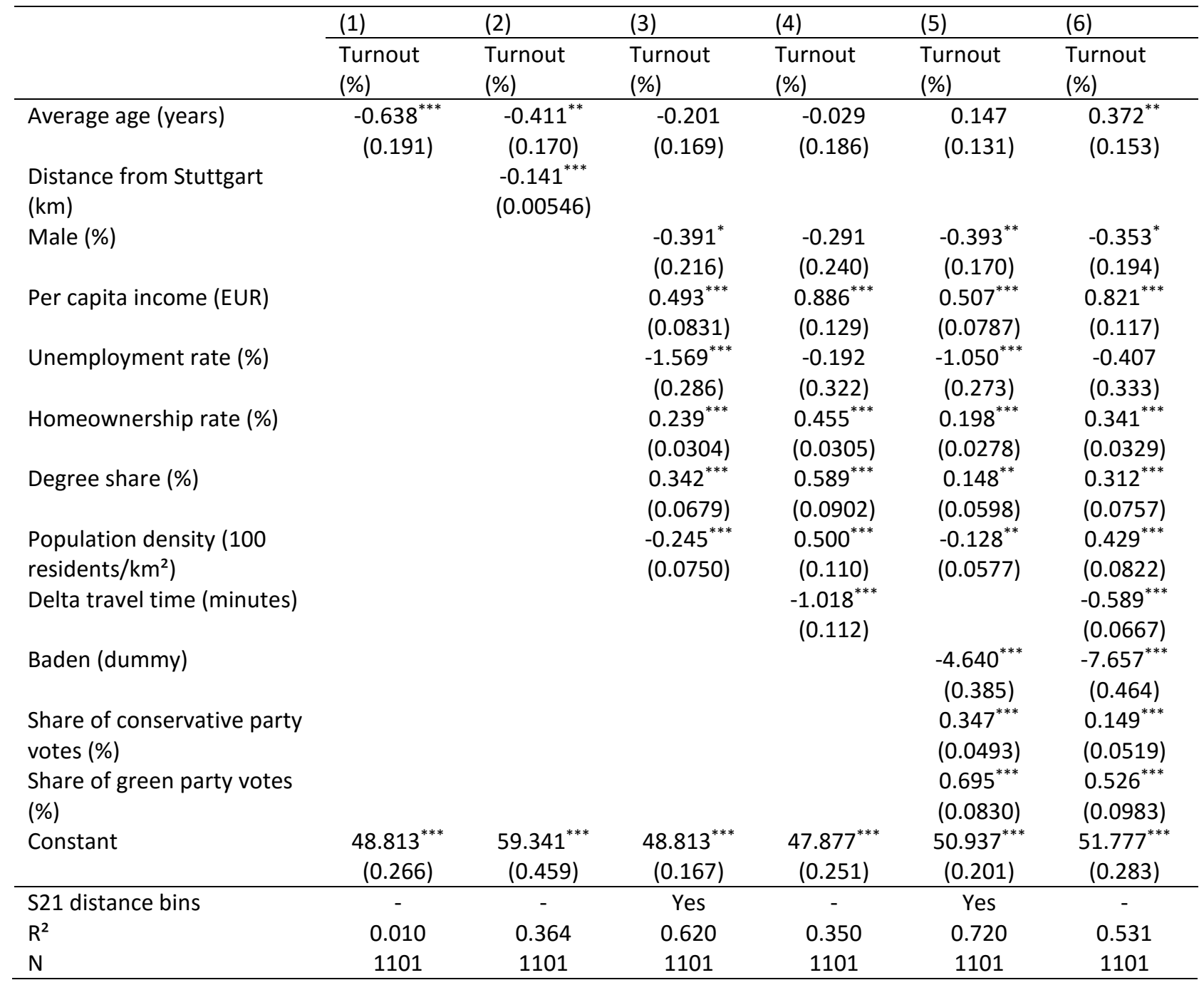

Notes: Average age refers to the adult population (the electorate). All variables are centered (zero mean) except for the distance measure. Stuttgart 21 distance bins are the fixed effects for mutually exclusive $10 \mathrm{~km}$ distance bins comprising municipalities within 0-5 km, 5-15 km, 15-25 km, etc. All variables refer to 2011, the year of the referendum, except political party shares, which stem from the 2009 federal elections. Robust standard errors are denoted in parentheses. ${ }^{*} \mathrm{p}<0.1,{ }^{* *} \mathrm{p}<0.05,{ }^{* * *} \mathrm{p}<0.01$. 


\section{Robustness and extensions}

\subsection{Alternative models: Complete estimates}

In Table A3, we report the complete results of the models summarized in Table 6 in the main paper. In Table A4, we replicate the models excluding political party controls. The coefficients of the covariates are qualitatively and quantitatively consistent with the results reported in Table 5 in the main paper. As with the benchmark models, the age effect is generally larger if party controls are excluded. 
Tab A3. Determinants of opposition to Stuttgart 21: Complete results of alternative models

\begin{tabular}{|c|c|c|c|c|c|c|}
\hline & $(1)$ & $(2)$ & (3) & (4) & $(5)$ & (6) \\
\hline & $\begin{array}{l}\text { Share yes } \\
\text { votes (\%) }\end{array}$ & $\begin{array}{l}\text { Share yes } \\
\text { votes (\%) }\end{array}$ & $\begin{array}{l}\text { Share yes } \\
\text { votes }(\%)\end{array}$ & $\begin{array}{l}\text { Share yes } \\
\text { votes (\%) }\end{array}$ & $\begin{array}{l}\text { Share yes } \\
\text { votes (\%) }\end{array}$ & $\begin{array}{l}\text { Share yes } \\
\text { votes }(\%)\end{array}$ \\
\hline & WLS & $\mathrm{BC}$ & OLS & OLS & OLS & OLS \\
\hline Average age (years) & $\begin{array}{c}0.559^{* * *} \\
(0.182)\end{array}$ & $\begin{array}{l}0.0326^{* * *} \\
(0.00539)\end{array}$ & $\begin{array}{c}0.764^{* * *} \\
(0.130)\end{array}$ & $\begin{array}{c}0.678^{* * *} \\
(0.141)\end{array}$ & $\begin{array}{c}0.732^{* * *} \\
(0.134)\end{array}$ & \\
\hline Share age $65<(\%)$ & & & & & & $\begin{array}{l}0.188^{* * *} \\
(0.0625)\end{array}$ \\
\hline $\begin{array}{l}\text { Distance from Stuttgart } \\
(\mathrm{km})\end{array}$ & $\begin{array}{l}0.0704^{* * *} \\
(0.00637)\end{array}$ & $\begin{array}{l}0.00295^{* * *} \\
(0.000193)\end{array}$ & $\begin{array}{l}0.0537^{* * *} \\
(0.0101)\end{array}$ & & & $\begin{array}{l}0.0765^{* * *} \\
(0.00457)\end{array}$ \\
\hline $\begin{array}{l}\text { Delta travel time } \\
\text { (minutes) }\end{array}$ & & & & $\begin{array}{c}0.103^{*} \\
(0.0524)\end{array}$ & & \\
\hline Turnout (instrumented) & & & $\begin{array}{l}-0.193^{* *} \\
(0.0758)\end{array}$ & & & \\
\hline Male (\%) & $\begin{array}{l}-0.347 \\
(0.212)\end{array}$ & $\begin{array}{c}0.00393 \\
(0.00713)\end{array}$ & $\begin{array}{c}0.159 \\
(0.160)\end{array}$ & $\begin{array}{c}0.259 \\
(0.163)\end{array}$ & $\begin{array}{c}0.236 \\
(0.166)\end{array}$ & $\begin{array}{l}0.0914 \\
(0.165)\end{array}$ \\
\hline Per capita income (EUR) & $\begin{array}{l}-0.0940 \\
(0.149)\end{array}$ & $\begin{array}{l}-0.00741^{* *} \\
(0.00351)\end{array}$ & $\begin{array}{c}-0.117 \\
(0.0880)\end{array}$ & $\begin{array}{l}-0.363^{* * *} \\
(0.0826)\end{array}$ & $\begin{array}{l}-0.241^{* * *} \\
(0.0760)\end{array}$ & $\begin{array}{l}-0.231^{* * *} \\
(0.0737)\end{array}$ \\
\hline Unemployment rate (\%) & $\begin{array}{c}0.382 \\
(0.359)\end{array}$ & $\begin{array}{c}0.0111 \\
(0.0105)\end{array}$ & $\begin{array}{c}0.110 \\
(0.250)\end{array}$ & $\begin{array}{l}-0.0969 \\
(0.270)\end{array}$ & $\begin{array}{c}0.291 \\
(0.258)\end{array}$ & $\begin{array}{c}0.410 \\
(0.257)\end{array}$ \\
\hline Homeownership rate (\%) & $\begin{array}{l}-0.0163 \\
(0.0780)\end{array}$ & $\begin{array}{l}-0.00389^{* *} \\
(0.00154)\end{array}$ & $\begin{array}{l}-0.0751^{* *} \\
(0.0298)\end{array}$ & $\begin{array}{l}-0.208^{* * *} \\
(0.0290)\end{array}$ & $\begin{array}{l}-0.107^{* * *} \\
(0.0292)\end{array}$ & $\begin{array}{c}-0.0980^{* * *} \\
(0.0285)\end{array}$ \\
\hline Degree share (\%) & $\begin{array}{l}0.175^{* * *} \\
(0.0615)\end{array}$ & $\begin{array}{l}0.00767^{* * *} \\
(0.00222)\end{array}$ & $\begin{array}{l}0.298^{* * *} \\
(0.0568)\end{array}$ & $\begin{array}{l}0.170^{* * *} \\
(0.0617)\end{array}$ & $\begin{array}{l}0.265^{* * *} \\
(0.0558)\end{array}$ & $\begin{array}{l}0.254^{* * *} \\
(0.0568)\end{array}$ \\
\hline $\begin{array}{l}\text { Population density (100 } \\
\text { residents } / \mathrm{km}^{2} \text { ) }\end{array}$ & $\begin{array}{c}0.217^{* *} \\
(0.0946)\end{array}$ & $\begin{array}{l}0.00709^{* * *} \\
(0.00231)\end{array}$ & $\begin{array}{l}0.254^{* * *} \\
(0.0569)\end{array}$ & $\begin{array}{l}-0.0191 \\
(0.0602)\end{array}$ & $\begin{array}{l}0.278^{* * *} \\
(0.0659)\end{array}$ & $\begin{array}{l}0.216^{* * *} \\
(0.0602)\end{array}$ \\
\hline Baden (dummy) & $\begin{array}{l}5.851^{* * *} \\
(0.748)\end{array}$ & $\begin{array}{l}0.233^{* * *} \\
(0.0172)\end{array}$ & $\begin{array}{l}4.409^{* * *} \\
(0.476)\end{array}$ & $\begin{array}{l}7.448^{* * *} \\
(0.371)\end{array}$ & $\begin{array}{l}5.402^{* * *} \\
(0.380)\end{array}$ & $\begin{array}{l}5.578^{* * *} \\
(0.360)\end{array}$ \\
\hline $\begin{array}{l}\text { Share conservative party } \\
\text { votes }(\%)\end{array}$ & $\begin{array}{l}-0.612^{* * *} \\
(0.0575)\end{array}$ & $\begin{array}{l}-0.0282^{* * *} \\
(0.00175)\end{array}$ & $\begin{array}{l}-0.563^{* * *} \\
(0.0457)\end{array}$ & $\begin{array}{l}-0.509^{* * *} \\
(0.0405)\end{array}$ & $\begin{array}{l}-0.618^{* * *} \\
(0.0421)\end{array}$ & $\begin{array}{l}-0.636^{* * *} \\
(0.0393)\end{array}$ \\
\hline $\begin{array}{l}\text { Share green party votes } \\
(\%)\end{array}$ & $\begin{array}{l}0.659^{* * *} \\
(0.114)\end{array}$ & $\begin{array}{l}0.0291^{* * *} \\
(0.00329)\end{array}$ & $\begin{array}{l}0.868^{* * *} \\
(0.104)\end{array}$ & $\begin{array}{l}0.968^{* * *} \\
(0.0856)\end{array}$ & $\begin{array}{l}0.682^{* * *} \\
(0.0884)\end{array}$ & $\begin{array}{l}0.691^{* * *} \\
(0.0856)\end{array}$ \\
\hline Constant & $\begin{array}{l}29.16^{* * *} \\
(0.506)\end{array}$ & $\begin{array}{l}-0.874^{* * *} \\
(0.0145)\end{array}$ & $\begin{array}{l}40.26^{* * *} \\
(4.534)\end{array}$ & $\begin{array}{l}33.53^{* * *} \\
(0.246)\end{array}$ & $\begin{array}{l}34.38^{* * *} \\
(0.237)\end{array}$ & $\begin{array}{l}28.58^{* * *} \\
(0.332)\end{array}$ \\
\hline S21 distance bins & - & - & - & - & Yes & - \\
\hline $\mathrm{R}^{2}$ & 0.807 & 0.742 & 0.766 & 0.693 & 0.745 & 0.737 \\
\hline $\mathrm{N}$ & 1101 & 1101 & 1101 & 1101 & 1101 & 1101 \\
\hline
\end{tabular}

Notes: Average age refers to the adult population (the electorate). All variables are centered (zero mean) except for the distance measure. Stuttgart 21 distance bins are the fixed effects for mutually exclusive $10 \mathrm{~km}$ distance bins comprising municipalities within 0-5 km, 5-15 km, 15-25 km, etc. Delta travel time is the expected average change in travel time to all other municipalities weighted by the share of out-commuters. The instrument in model (3) is the turnout in the 2009 federal elections. All variables refer to 2011, the year of the referendum, except political party shares, which stem from the 2009 federal elections. $* \mathrm{p}<0.1$, ** $\mathrm{p}<0.05$, $* * * \mathrm{p}<0.01$. 
Tab A4. Determinants of opposition to Stuttgart 21: Alternative models excluding political controls

\begin{tabular}{|c|c|c|c|c|c|c|}
\hline & (1) & (2) & (3) & (4) & (5) & (6) \\
\hline & $\begin{array}{l}\text { Share yes } \\
\text { votes (\%) }\end{array}$ & $\begin{array}{l}\text { Share yes } \\
\text { votes (\%) }\end{array}$ & $\begin{array}{l}\text { Share yes } \\
\text { votes (\%) }\end{array}$ & $\begin{array}{l}\text { Share yes } \\
\text { votes (\%) }\end{array}$ & $\begin{array}{l}\text { Share yes } \\
\text { votes (\%) }\end{array}$ & $\begin{array}{l}\text { Share yes } \\
\text { votes (\%) }\end{array}$ \\
\hline & WLS & $\mathrm{BC}$ & OLS & OLS & OLS & OLS \\
\hline Average age (years) & $\begin{array}{l}0.475^{*} \\
(0.246)\end{array}$ & $\begin{array}{l}0.0387^{* * *} \\
(0.00822)\end{array}$ & $\begin{array}{l}1.145^{* * *} \\
(0.186)\end{array}$ & $\begin{array}{l}1.186^{* * *} \\
(0.204)\end{array}$ & $\begin{array}{l}1.189^{* * *} \\
(0.183)\end{array}$ & \\
\hline Share age $65<(\%)$ & & & & & & $\begin{array}{l}0.247^{* * *} \\
(0.0921)\end{array}$ \\
\hline $\begin{array}{l}\text { Distance from Stuttgart } \\
(\mathrm{km})\end{array}$ & $\begin{array}{l}0.0999^{* * *} \\
(0.00846)\end{array}$ & $\begin{array}{l}0.00404^{* * *} \\
(0.000258)\end{array}$ & $\begin{array}{l}0.0601^{* * *} \\
(0.0125)\end{array}$ & & & $\begin{array}{l}0.106^{* * *} \\
(0.00652)\end{array}$ \\
\hline Delta travel time (minutes) & & & & $\begin{array}{l}0.506^{* * *} \\
(0.0936)\end{array}$ & & \\
\hline Male (\%) & $\begin{array}{l}-1.385^{* * *} \\
(0.391)\end{array}$ & $\begin{array}{l}-0.0335^{* *} \\
(0.0135)\end{array}$ & $\begin{array}{l}-0.162 \\
(0.337)\end{array}$ & $\begin{array}{l}-0.0453 \\
(0.382)\end{array}$ & $\begin{array}{l}0.106 \\
(0.344)\end{array}$ & $\begin{array}{l}-0.361 \\
(0.352)\end{array}$ \\
\hline Per capita income (EUR) & $\begin{array}{l}-0.173 \\
(0.142)\end{array}$ & $\begin{array}{l}-0.000687 \\
(0.00438)\end{array}$ & $\begin{array}{l}0.352^{* * *} \\
(0.134)\end{array}$ & $\begin{array}{l}-0.0351 \\
(0.125)\end{array}$ & $\begin{array}{l}0.00204 \\
(0.102)\end{array}$ & $\begin{array}{l}0.139 \\
(0.113)\end{array}$ \\
\hline Unemployment rate (\%) & $\begin{array}{l}0.333 \\
(0.376)\end{array}$ & $\begin{array}{l}0.00968 \\
(0.0132)\end{array}$ & $\begin{array}{l}0.0460 \\
(0.349)\end{array}$ & $\begin{array}{l}-0.698^{*} \\
(0.357)\end{array}$ & $\begin{array}{l}0.170 \\
(0.335)\end{array}$ & $\begin{array}{l}0.859^{* *} \\
(0.346)\end{array}$ \\
\hline Homeownership rate (\%) & $\begin{array}{l}-0.115 \\
(0.0867)\end{array}$ & $\begin{array}{l}-0.00942^{* * *} \\
(0.00186)\end{array}$ & $\begin{array}{l}-0.234^{* * *} \\
(0.0407)\end{array}$ & $\begin{array}{l}-0.517^{* * *} \\
(0.0391)\end{array}$ & $\begin{array}{l}-0.318^{* * *} \\
(0.0397)\end{array}$ & $\begin{array}{l}-0.281^{* * *} \\
(0.0415)\end{array}$ \\
\hline Degree share (\%) & $\begin{array}{l}0.646^{* * *} \\
(0.0900)\end{array}$ & $\begin{array}{l}0.0254^{* * *} \\
(0.00316)\end{array}$ & $\begin{array}{l}0.802^{* * *} \\
(0.0908)\end{array}$ & $\begin{array}{l}0.549^{* * *} \\
(0.0836)\end{array}$ & $\begin{array}{l}0.523^{* * *} \\
(0.0791)\end{array}$ & $\begin{array}{l}0.621^{* * *} \\
(0.0803)\end{array}$ \\
\hline $\begin{array}{l}\text { Population density } \quad(100 \\
\left.\text { residents } / \mathrm{km}^{2}\right) \\
\text { Constant }\end{array}$ & $\begin{array}{l}0.279^{* *} \\
(0.126) \\
29.76^{* * *} \\
(0.634)\end{array}$ & $\begin{array}{l}0.0110^{* * *} \\
(0.00353) \\
-0.840^{* * *} \\
(0.0197)\end{array}$ & $\begin{array}{l}0.360^{* * *} \\
(0.0777) \\
48.57^{* * *} \\
(4.900)\end{array}$ & $\begin{array}{l}-0.0604 \\
(0.0850) \\
37.31^{* * *} \\
(0.255) \\
\end{array}$ & $\begin{array}{l}0.457^{* * *} \\
(0.0875) \\
36.85^{* * *} \\
(0.204)\end{array}$ & $\begin{array}{l}0.314^{* * *} \\
(0.0841) \\
28.96^{* * *} \\
(0.494)\end{array}$ \\
\hline S21 distance bins & - & 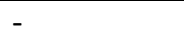 & - & - & Yes & - \\
\hline $\mathrm{R}^{2}$ & 0.648 & 0.517 & 0.541 & 0.393 & 0.530 & 0.477 \\
\hline $\mathrm{N}$ & 1101 & 1101 & 1101 & 1101 & 1101 & 1101 \\
\hline
\end{tabular}

Notes: Average age refers to the adult population (the electorate). All variables are centered (zero mean) except for the distance measure. Stuttgart 21 distance bins are the fixed effects for mutually exclusive $10 \mathrm{~km}$ distance bins comprising municipalities within 0-5 km, 5-15 km, 15-25 km, etc. Delta travel time is the expected average change in travel time to all other municipalities weighted by the share of out-commuters. The instrument in model (3) is the turnout in the 2009 federal elections. All variables refer to 2011, the year of the referendum, except political party shares, which stem from the 2009 federal elections. $* \mathrm{p}<0.1, * * \mathrm{p}<0.05$, $* * * \mathrm{p}<0.01$.

\subsection{Non-parametric vs. parametric distance to Stuttgart 21 effects}

Our benchmark models control for proximity to Stuttgart 21 using a linear distance measure. In model (5) of Table 6 in the main paper, we allow for a more flexible functional form by allowing for arbitrary effects within $10 \mathrm{~km}$ distance bins. In Figure A5, we compare the distance effect implied by the parametric benchmark specification to the non-parametric bin estimates. It is observed that the parametric functional form is well-aligned with the estimated bin effects. The only notable exceptions are the first and last distance bins, which comprise only few municipalities (the first bin comprises Stuttgart exclusively). 
Fig. A5. Determinants of opposition to Stuttgart 21: Parametric vs. non-parametric distance from Stuttgart effect

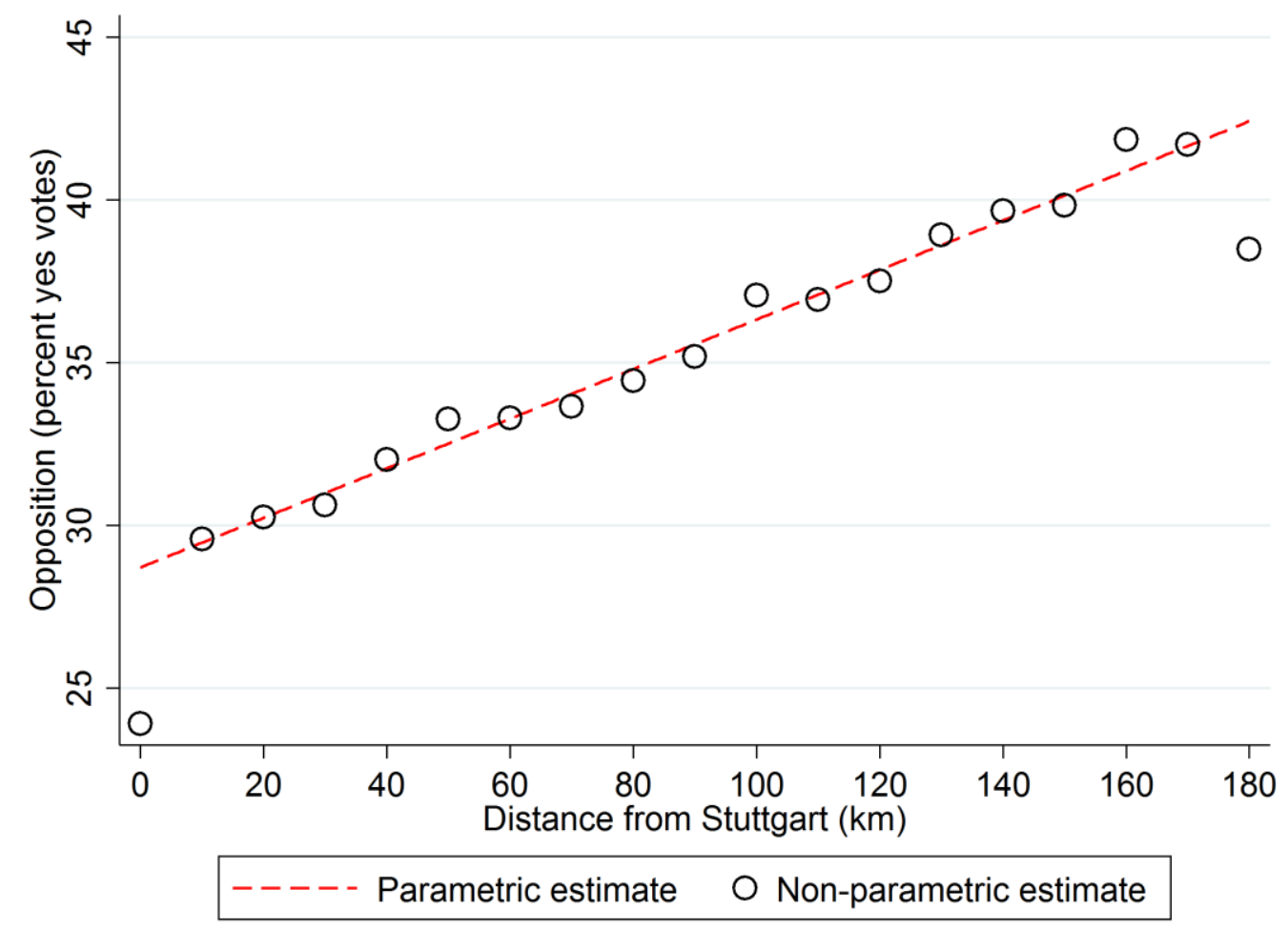

Notes: All estimates are conditional on average age, and socio-economic and political covariates. Parametric estimates are based on model (4) in Table 5 in the main paper. Non-parametric estimates are the $10 \mathrm{~km}$ distance from Stuttgart bin effects from model (5) in Table 6 in the main paper. The first distance bin contains Stuttgart exclusively.

\section{Interaction models}

Table A6 presents the estimates of the interaction effects between our measure of average age and the covariates discussed in Section 3.5 of the main paper. Among the significant interaction effects, two are particularly interesting with respect to related literature. The baseline models suggest a relatively strong relationship between homeownership rate and support for Stuttgart 21. To the extent that Stuttgart 21 was expected to increase property prices, this empirical relationship can be rationalized with an asset gain or wealth motive as discussed in the literature on the homevoter hypothesis (Ahlfeldt and Maennig, 2015; Dehring et al., 2008; Fischel, 2001). The positive interaction effect between the homeownership rate and average age suggests that it is particularly the young homeowners who vote according to such a wealth motive. This is intuitive since younger homeowners, during their remaining lifetime, are more likely to sell their property.

The other interesting effect is the positive interaction between the average age and the share of male voters. The fact that the opposition to the Stuttgart 21 by the elderly is driven particularly by 
male voters is consistent with behavioral economics results suggesting that women are more altruistic, especially if altruism is expensive (Andreoni and Vesterlund, 2001).

Tab A5. Determinants of opposition to Stuttgart 21: Interaction models

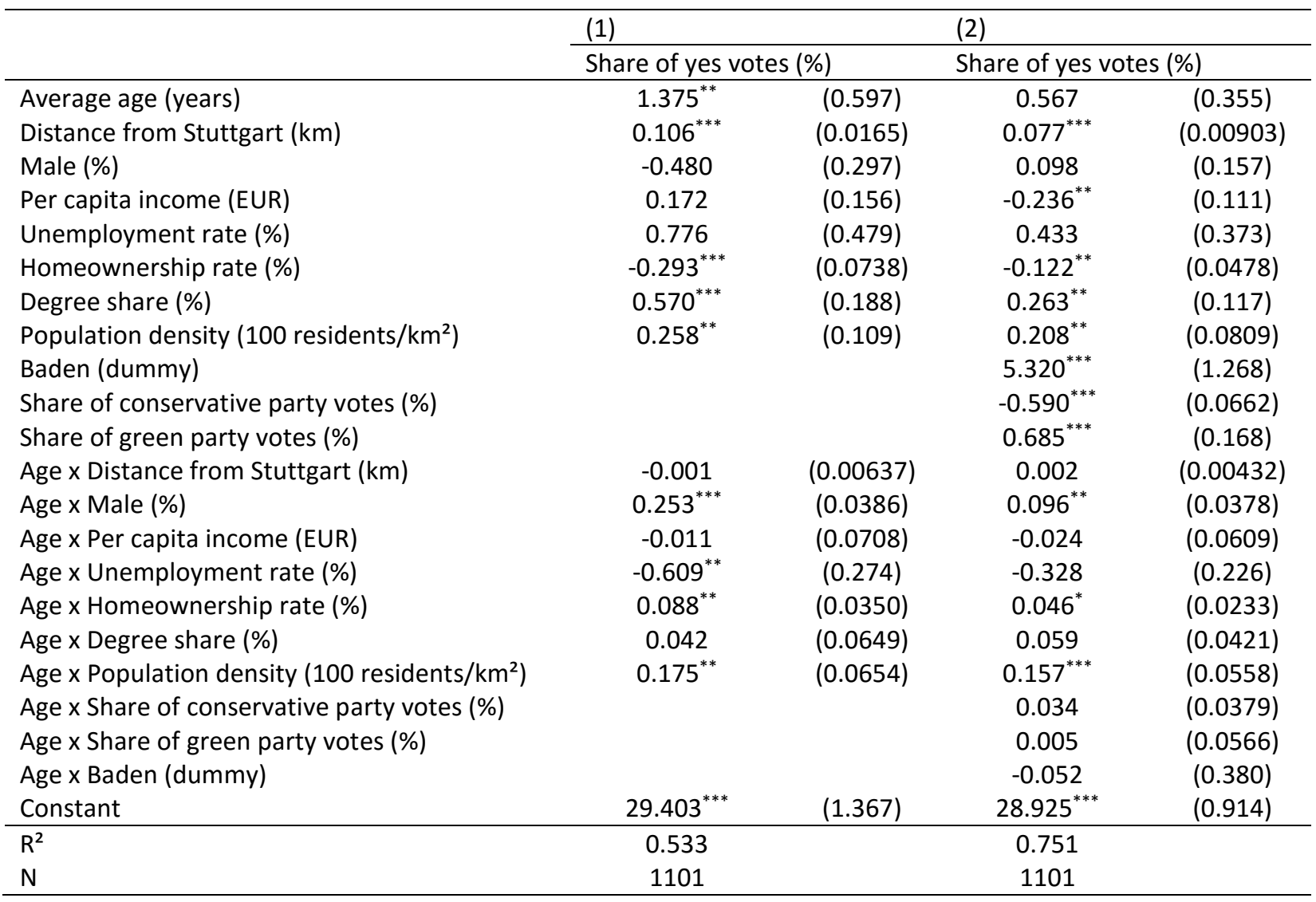

Notes: Ordinary Least Squares (OLS) estimates. All variables are centered (zero mean) except for the distance measure. All variables refer to 2011, the year of the referendum, except political party shares, which stem from the 2009 federal elections. White-robust standard errors are denoted in parentheses. ${ }^{*} \mathrm{p}<0.1,{ }^{* *}$ $\mathrm{p}<0.05, * * \mathrm{p}<0.01$.

\section{Instrumental variables: Complementary results}

In Table 7 in the main paper, we used historic sector shares and historic shares of children as instruments for the average age. In Table A6, we replicate Table 7, model (3) using either historic sector shares (column 1) or historic children shares (column 2) as instruments for age. We also use an alternative set of instruments, the change in shares of the secondary and tertiary sectors from 1961 to 1970 and 1970 to 1987 (columns 3 and 6)). The economic rationale is similar to that for the historic shares. A favorable industrial transformation at some point should have attracted a mobile labor force, which, as long as a significant fraction of the population stays put, should have a legacy effect on the contemporary age structure. Since we assume that historic changes in sectoral changes are uncorrelated with contemporary levels of sectoral shares, we do not control 
for the latter in this model. We combine all three instrumental variable approaches with an instrumented control for the turnout (columns 4-6), and find positive and statistically significant age effects in all models.

Tab A6. Determinants of opposition to Stuttgart 21: Alternative 2SLS models

\begin{tabular}{|c|c|c|c|c|c|c|}
\hline & $(1)$ & $(2)$ & (3) & (4) & $(5)$ & (6) \\
\hline & $\begin{array}{l}\text { Share of } \\
\text { yes votes } \\
(\%)\end{array}$ & $\begin{array}{l}\text { Share of } \\
\text { yes votes } \\
\text { (\%) }\end{array}$ & $\begin{array}{l}\text { Share of } \\
\text { yes votes } \\
\text { (\%) }\end{array}$ & $\begin{array}{l}\text { Share of } \\
\text { yes votes } \\
\text { (\%) }\end{array}$ & $\begin{array}{l}\text { Share of } \\
\text { yes votes } \\
(\%)\end{array}$ & $\begin{array}{l}\text { Share of } \\
\text { yes votes } \\
(\%)\end{array}$ \\
\hline \multirow[t]{2}{*}{ Average age (instrumented) } & $1.804^{* *}$ & $6.544^{* *}$ & $2.001^{* * *}$ & $2.238^{* *}$ & $6.226^{* *}$ & $1.612^{* * *}$ \\
\hline & (0.919) & (3.169) & $(0.589)$ & $(0.968)$ & $(2.801)$ & $(0.565)$ \\
\hline Distance from Stuttgart & $0.106^{* * *}$ & $0.093^{* * *}$ & $0.102^{* * *}$ & 0.048 & 0.002 & $0.020^{*}$ \\
\hline$(\mathrm{km})$ & (0.019) & $(0.021)$ & $(0.007)$ & $(0.034)$ & $(0.029)$ & $(0.012)$ \\
\hline Share of secondary sector & 3.538 & 0.958 & & 0.582 & -3.272 & \\
\hline $2011(\%)$ & (3.353) & $(3.452)$ & & $(2.655)$ & $(3.452)$ & \\
\hline Share of tertiary sector & 3.796 & 1.175 & & 0.802 & -3.107 & \\
\hline $2011(\%)$ & (3.392) & (3.513) & & $(2.691)$ & $(3.520)$ & \\
\hline \multirow[t]{2}{*}{ Turnout (instrumented) } & & & & $-0.387^{* *}$ & $-0.627^{* * *}$ & $-0.631^{* * *}$ \\
\hline & & & & $(0.180)$ & $(0.139)$ & $(0.076)$ \\
\hline Socio-economic controls & Yes & Yes & Yes & Yes & Yes & Yes \\
\hline Industry IV & - & Yes & - & - & Yes & - \\
\hline Delta Industry IV & - & - & Yes & - & - & Yes \\
\hline Age IV & Yes & - & - & Yes & - & - \\
\hline Turnout 2009 IV & - & - & - & Yes & Yes & Yes \\
\hline CDF F Stat & 30.955 & 11.065 & 25.679 & 21.141 & 9.608 & 21.019 \\
\hline Hansen J P & 0.722 & 0.045 & 0.000 & 0.799 & 0.509 & 0.000 \\
\hline $\mathrm{R}^{2}$ & 0.518 & 0.012 & 0.484 & 0.537 & 0.069 & 0.501 \\
\hline $\mathrm{N}$ & 1101 & 1101 & 1101 & 1101 & 1101 & 1101 \\
\hline
\end{tabular}

Notes: The estimation method is 2SLS in all models. Socio-economic controls are the same as in Table 5 in the main paper. Industry IV represents the shares of the secondary and tertiary sectors in 1961 and 1970 (countylevel). $\Delta$ Industry IV are the changes in the shares of the same sectors from 1961 to 1970 and from 1970 to 1987. Age IV represents the shares of the population aged 0-5 and 6-15 years in 1950 and 1961 (municipality-level). Standard errors are clustered on counties in all models controlling for contemporary industry shares. ${ }^{*} p<0.1,{ }^{* *} p<0.05,{ }^{* * *} p<0.01$. 


\section{Literature}

Ahlfeldt, G. M., and Maennig, W. (2015). Homevoters vs. leasevoters: A spatial analysis of airport effects. Journal of Urban Economics, 87(0), 85-99.

Ahlfeldt, G. M., Redding, S. J., Sturm, D. M., and Wolf, N. (2015). The Economics of Density: Evidence from the Berlin Wall. Econometrica, 83(6), 2127-2189.

Andreoni, J., and Vesterlund, L. (2001). Which is the Fair Sex? Gender Differences in Altruism. The Quarterly Journal of Economics, 116(1), 293-312.

Angrist, J. D., and Pischke, J.-S. (2009). Mostly Harmless Econometrics: An Empiricist's Companion. Princeton, New Jersey: Princeton University Press.

Dehring, C. A., Depken, C. A., and Ward, M. R. (2008). A direct test of the homevoter hypothesis. Journal of Urban Economics, 64(1), 155-170.

Fischel, W. A. (2001). The Homevoter Hypothesis. Cambridge, MA: Harvard University Press.

SMA und Partner AG. (2010). Stuttgart 21 und Kopfbahnhof 21: Vergleichende Analyse der Reisezeiten. Zurich. 
Tab A1. Summary of referenda analyzed

\begin{tabular}{|c|c|c|c|c|c|c|c|c|c|c|}
\hline$\#$ & ID & Year & Author & Category & Referendum & Age variable ${ }^{a}$ & & Elderly Attitude & & Note \\
\hline 1 & 1 & 1977 & Rubinfeld & $\begin{array}{l}\text { School } \\
\text { spending }\end{array}$ & $\begin{array}{l}\text { Renewal of school taxes in } \\
\text { Troy, Michigan, May election }\end{array}$ & $\begin{array}{l}\text { Having children in } \\
\text { school }\end{array}$ & Opposition & Individualistic & Change & $\begin{array}{l}\text { Not having school-aged chil- } \\
\text { dren (correlated with age) }\end{array}$ \\
\hline 2 & 1 & 1977 & Rubinfeld & $\begin{array}{l}\text { School } \\
\text { spending }\end{array}$ & $\begin{array}{l}\text { Renewal of school taxes in } \\
\text { Troy, Michigan, June election }\end{array}$ & $\begin{array}{l}\text { Having children in } \\
\text { school }\end{array}$ & Opposition & Individualistic & Change & $\begin{array}{l}\text { leads to opposition to renewal } \\
\text { of school taxes. }\end{array}$ \\
\hline 3 & 2 & 1979 & Fischel & $\begin{array}{c}\text { Urban } \\
\text { development }\end{array}$ & $\begin{array}{c}\text { New pulp mill in New Hamp- } \\
\text { shire }\end{array}$ & $\begin{array}{c}\text { Share of retired } \\
\text { population and av- } \\
\text { erage age }\end{array}$ & $\begin{array}{l}\text { Not signifi- } \\
\text { cant }\end{array}$ & Neutral & Neutral & $\begin{array}{l}\text { Retired and age effects tend to } \\
\text { cancel each other out. }\end{array}$ \\
\hline 4 & 3 & 1982 & Noam & Welfare & $\begin{array}{l}\text { Unemployment benefits, not } \\
\text { specified further }\end{array}$ & Age & $\begin{array}{c}\text { Not } \\
\text { significant }\end{array}$ & Neutral & Neutral & \multirow{12}{*}{$\begin{array}{l}\text { This study assumes that age is } \\
\text { a covariate in all analyses of } \\
\text { referenda, but is reported only } \\
\text { where significant. The number } \\
\text { of children is significant in } \\
\text { some referenda. Because the } \\
\text { age of children is not specified, } \\
\text { it is not possible to infer an } \\
\text { elderly effect. }\end{array}$} \\
\hline 5 & 3 & 1982 & Noam & $\begin{array}{l}\text { Health ser- } \\
\text { vices }\end{array}$ & $\begin{array}{c}\text { Hospitals, not specified fur- } \\
\text { ther }\end{array}$ & Age & Support & Individualistic & Status quo & \\
\hline 6 & 3 & 1982 & Noam & Welfare & $\begin{array}{l}\text { Welfare subsidies, not speci- } \\
\text { fied further }\end{array}$ & Age & $\begin{array}{l}\text { Not } \\
\text { significant }\end{array}$ & Neutral & Neutral & \\
\hline 7 & 3 & 1982 & Noam & Transportation & $\begin{array}{c}\text { Highways, not specified fur- } \\
\text { ther }\end{array}$ & Age & Opposition & Individualistic & Status quo & \\
\hline 8 & 3 & 1982 & Noam & Transportation & $\begin{array}{l}\text { Mass transit, not specified } \\
\text { further }\end{array}$ & Age & Support & Collectivistic & Change & \\
\hline 9 & 3 & 1982 & Noam & $\begin{array}{l}\text { Law } \\
\text { enforcement }\end{array}$ & $\begin{array}{l}\text { Prosecutor, not specified } \\
\text { further }\end{array}$ & Age & $\begin{array}{c}\text { Not } \\
\text { significant }\end{array}$ & Neutral & Neutral & \\
\hline 10 & 3 & 1982 & Noam & Infrastructure & Prison, not specified further & Age & $\begin{array}{l}\text { Not } \\
\text { significant }\end{array}$ & Neutral & Neutral & \\
\hline 11 & 3 & 1982 & Noam & $\begin{array}{l}\text { Health } \\
\text { services }\end{array}$ & $\begin{array}{l}\text { Old-aged home, not specified } \\
\text { further }\end{array}$ & Age & Support & Individualistic & Status quo & \\
\hline 12 & 3 & 1982 & Noam & $\begin{array}{l}\text { Sports } \\
\text { facility }\end{array}$ & $\begin{array}{l}\text { Sports facilities, not specified } \\
\text { further }\end{array}$ & Age & $\begin{array}{c}\text { Not } \\
\text { significant }\end{array}$ & Neutral & Neutral & \\
\hline 13 & 3 & 1982 & Noam & Culture & $\begin{array}{c}\text { Museum, not specified fur- } \\
\text { ther }\end{array}$ & Age & $\begin{array}{c}\text { Not } \\
\text { significant }\end{array}$ & Neutral & Neutral & \\
\hline 14 & 3 & 1982 & Noam & $\begin{array}{l}\text { School } \\
\text { spending }\end{array}$ & $\begin{array}{l}\text { Educational expenditure, not } \\
\text { specified further }\end{array}$ & Age & $\begin{array}{c}\text { Not } \\
\text { significant }\end{array}$ & Neutral & Neutral & \\
\hline 15 & 3 & 1982 & Noam & Foreign aid & $\begin{array}{c}\text { Foreign aid, not specified } \\
\text { further }\end{array}$ & Age & $\begin{array}{c}\text { Not } \\
\text { significant }\end{array}$ & Neutral & Neutral & \\
\hline
\end{tabular}




\begin{tabular}{|c|c|c|c|c|c|c|c|c|c|c|}
\hline$\#$ & ID & Year & Author & Category & Referendum & Age variable ${ }^{a}$ & & Elderly Attitude $^{b}$ & & Note \\
\hline 16 & 4 & 1983 & Ladd \& Wilson & $\begin{array}{l}\text { School } \\
\text { spending }\end{array}$ & $\begin{array}{c}\text { Massachusetts' Proposition } 2 \\
1 / 2 \text { to restrict property tax. } \\
\text { Would reduce school spend- } \\
\text { ing }\end{array}$ & Age $>60$ (dummy) & Support & Individualistic & Change & $\begin{array}{l}\text { While other types of spending } \\
\text { could also be affected in theo- } \\
\text { ry, the implications for educa- } \\
\text { tional spending are reported to } \\
\text { be the most obvious. }\end{array}$ \\
\hline 17 & 5 & 1983 & Pelinka & Energy & $\begin{array}{l}\text { Introduction of nuclear ener- } \\
\text { gy, Austrian Nuclear Referen- } \\
\text { dum, } 1987\end{array}$ & Age $>50$ (dummy) & Support & Individualistic & Change & Descriptive analysis \\
\hline 18 & 6 & 1988 & $\begin{array}{c}\text { Feigenbaum et } \\
\text { al. }\end{array}$ & Energy & $\begin{array}{l}\text { Ban nuclear energy, Nuclear } \\
\text { Freeze Referendum in } 10 \text { US } \\
\text { states }\end{array}$ & Average age & $\begin{array}{c}\text { Not } \\
\text { significant }\end{array}$ & Neutral & Neutral & \\
\hline 19 & 7 & 1992 & Button & $\begin{array}{c}\text { School } \\
\text { spending }\end{array}$ & $\begin{array}{l}\text { Introduce school bonds, Her- } \\
\text { nando, Florida }\end{array}$ & Share $>55$ & Opposition & Individualistic & Status quo & \multirow{5}{*}{$\begin{array}{l}\text { The study also analyzes local } \\
\text { tax issue referenda. The elderly } \\
\text { voted against spending in two } \\
\text { out of five cases. These elec- } \\
\text { tions were not encoded as the } \\
\text { nature of anticipated spending } \\
\text { was not clear. }\end{array}$} \\
\hline 20 & 7 & 1992 & Button & $\begin{array}{l}\text { School } \\
\text { spending }\end{array}$ & $\begin{array}{l}\text { Introduce school bonds, Indi- } \\
\text { an River, Florida }\end{array}$ & Share $>55$ & Opposition & Individualistic & Status quo & \\
\hline 21 & 7 & 1992 & Button & $\begin{array}{l}\text { School } \\
\text { spending }\end{array}$ & $\begin{array}{c}\text { Introduce school bonds, Lake, } \\
\text { Florida }\end{array}$ & Share $>55$ & Opposition & Individualistic & Status quo & \\
\hline 22 & 7 & 1992 & Button & $\begin{array}{l}\text { School } \\
\text { spending }\end{array}$ & $\begin{array}{l}\text { Introduce school bonds, Mar- } \\
\text { ion, Florida }\end{array}$ & Share $>55$ & Opposition & Individualistic & Status quo & \\
\hline 24 & 7 & 1992 & Button & $\begin{array}{l}\text { School } \\
\text { spending }\end{array}$ & $\begin{array}{l}\text { Introduce school bonds, Char- } \\
\text { lotte, Florida }\end{array}$ & Share $>55$ & $\begin{array}{l}\text { Not signifi- } \\
\text { cant }\end{array}$ & Neutral & Neutral & \\
\hline 25 & 8 & 1997 & Agostini et al. & Sports facility & $\begin{array}{c}\text { Stadium initiative, San Fran- } \\
\text { cisco, } 1989\end{array}$ & Not reported & $\begin{array}{c}\text { Not } \\
\text { significant }\end{array}$ & Neutral & Neutral & \multirow{2}{*}{$\begin{array}{l}\text { No estimation results reported } \\
\text { but age effects reported to be } \\
\text { marginal. }\end{array}$} \\
\hline 26 & 8 & 1997 & Agostini et al. & Sports facility & $\begin{array}{c}\text { Stadium initiative, San Fran- } \\
\text { cisco, } 1996\end{array}$ & Not reported & $\begin{array}{c}\text { Not } \\
\text { significant }\end{array}$ & Neutral & Neutral & \\
\hline 27 & 9 & 2000 & $\begin{array}{l}\text { Schulze \& } \\
\text { Ursprung }\end{array}$ & Culture & $\begin{array}{c}\text { Subsidies to Opera House, } \\
\text { Zurich, } 1994\end{array}$ & Share $65-79$ & $\begin{array}{c}\text { Not } \\
\text { significant }\end{array}$ & Neutral & Neutral & $\begin{array}{c}\text { Estimation result discussed but } \\
\text { not reported. }\end{array}$ \\
\hline 28 & 10 & 2003 & Balsdon et al. & $\begin{array}{l}\text { School } \\
\text { spending }\end{array}$ & $\begin{array}{l}\text { School bond proposals, Cali- } \\
\text { fornia, 1995-2000 }\end{array}$ & Share $>65$ & $\begin{array}{l}\text { Not signifi- } \\
\text { cant }\end{array}$ & Neutral & Neutral & $\begin{array}{c}\text { The result is from the state } \\
\text { initiative. The local initiative is } \\
\text { not considered because it is } \\
\text { hypothetical. }\end{array}$ \\
\hline
\end{tabular}




\begin{tabular}{|c|c|c|c|c|c|c|c|c|c|c|}
\hline \# & ID & Year & Author & Category & Referendum & Age variable $^{a}$ & \multicolumn{3}{|c|}{ Elderly Attitude $^{b}$} & Note \\
\hline 29 & 11 & 2004 & $\begin{array}{c}\text { Brunner \& } \\
\text { Balsdon }\end{array}$ & $\begin{array}{l}\text { School } \\
\text { spending }\end{array}$ & $\begin{array}{l}\text { School bond, Proposition 47, } \\
\text { California, } 2007\end{array}$ & Dummy $>55$ & Opposition & Individualistic & Status quo & \\
\hline 30 & 12 & 2004 & Thalmann & Energy & $\begin{array}{l}\text { Green tax reform, Switzer- } \\
\text { land, } 2000\end{array}$ & Dummy $>60$ & Opposition & Individualistic & Status quo & \\
\hline 31 & 12 & 2004 & Thalmann & Energy & $\begin{array}{l}\text { Energy conservation package, } \\
\text { Switzerland, } 2000\end{array}$ & Dummy $>60$ & Opposition & Individualistic & Status quo & referenda as Bornstein \& Lanz \\
\hline 32 & 12 & 2004 & Thalmann & Energy & $\begin{array}{c}\text { Solar initiative, Switzerland, } \\
2000\end{array}$ & Dummy $>60$ & Opposition & Individualistic & Status quo & \\
\hline 33 & 13 & 2005 & Hobolt & Integration & EMU, Denmark, 2000 & Age & $\begin{array}{c}\text { Not } \\
\text { significant }\end{array}$ & Neutral & Neutral & \\
\hline 34 & 13 & 2005 & Hobolt & Integration & EC Accession, Norway, 1972 & Age & $\begin{array}{c}\text { Not } \\
\text { significant }\end{array}$ & Neutral & Neutral & \\
\hline 35 & 13 & 2005 & Hobolt & Integration & Nice Treaty, Ireland, 2002 & Age & $\begin{array}{c}\text { Not } \\
\text { significant }\end{array}$ & Neutral & Neutral & \\
\hline 36 & 13 & 2005 & Hobolt & Integration & EU Accession, Norway, 1994 & Age & $\begin{array}{c}\text { Not } \\
\text { significant }\end{array}$ & Neutral & Neutral & \\
\hline 37 & 13 & 2005 & Hobolt & Integration & Nice Treaty, Ireland, 2001 & Age & $\begin{array}{c}\text { Not } \\
\text { significant }\end{array}$ & Neutral & Neutral & \\
\hline 38 & 13 & 2005 & Hobolt & Integration & $\begin{array}{c}\text { Maastricht Treaty, Denmark, } \\
1992\end{array}$ & Age & $\begin{array}{c}\text { Not } \\
\text { significant }\end{array}$ & Neutral & Neutral & \\
\hline 39 & 13 & 2005 & Hobolt & Integration & EC Accession, Denmark, 1973 & Age & $\begin{array}{c}\text { Not } \\
\text { significant }\end{array}$ & Neutral & Neutral & \\
\hline 40 & 13 & 2005 & Hobolt & Integration & $\begin{array}{c}\text { Maastricht Treaty, Denmark, } \\
1993\end{array}$ & Age & $\begin{array}{c}\text { Not } \\
\text { significant }\end{array}$ & Neutral & Neutral & \\
\hline 41 & 14 & 2005 & Rushton & Culture & $\begin{array}{c}\text { Increase in property taxes } \\
\text { with proceeds earmarked for } \\
\text { culture, Detroit, } 2002\end{array}$ & Share $>65$ & $\begin{array}{c}\text { Not } \\
\text { significant }\end{array}$ & Neutral & Neutral & \\
\hline 42 & 15 & 2006 & $\begin{array}{l}\text { Coates \& } \\
\text { Humphreys }\end{array}$ & Sports facility & $\begin{array}{l}\text { Football stadium in Green } \\
\text { Bey, Wisconsin } 2000\end{array}$ & Share $>65$ & $\begin{array}{c}\text { Not } \\
\text { significant }\end{array}$ & Neutral & Neutral & \\
\hline 43 & 15 & 2006 & $\begin{array}{l}\text { Coates \& } \\
\text { Humphreys }\end{array}$ & Sports facility & $\begin{array}{c}\text { Basketball arena in Houston, } \\
\text { Texas, } 1999\end{array}$ & Share $>65$ & $\begin{array}{l}\text { Not } \\
\text { significant }\end{array}$ & Neutral & Neutral & \\
\hline 44 & 15 & 2006 & $\begin{array}{l}\text { Coates \& } \\
\text { Humphreys }\end{array}$ & Sports facility & $\begin{array}{c}\text { Basketball arena in Houston, } \\
\text { Texas, } 2000\end{array}$ & Share $>65$ & Opposition & Individualistic & Status quo & \\
\hline
\end{tabular}




\begin{tabular}{|c|c|c|c|c|c|c|c|c|c|c|}
\hline$\#$ & ID & Year & Author & Category & Referendum & Age variable $^{\mathrm{a}}$ & & Elderly Attitude & & Note \\
\hline 45 & 16 & 2006 & $\begin{array}{l}\text { Kotchen \& } \\
\text { Powers }\end{array}$ & $\begin{array}{c}\text { Urban } \\
\text { development }\end{array}$ & $\begin{array}{c}857 \text { pooled US referenda on } \\
\text { open-space conservation, US, } \\
1998-2003\end{array}$ & Share $>65$ & Support & Individualistic & Change & \multirow[b]{3}{*}{$\begin{array}{c}\text { The effect is not significant in } \\
\text { all models, but is qualitatively } \\
\text { consistent. }\end{array}$} \\
\hline 46 & 16 & 2006 & $\begin{array}{l}\text { Kotchen \& } \\
\text { Powers }\end{array}$ & $\begin{array}{c}\text { Urban } \\
\text { development }\end{array}$ & $\begin{array}{c}\text { Open-space conservation, } \\
\text { New Jersey }\end{array}$ & Share $>65$ & Support & Individualistic & Change & \\
\hline 47 & 16 & 2006 & $\begin{array}{l}\text { Kotchen \& } \\
\text { Powers }\end{array}$ & $\begin{array}{c}\text { Urban } \\
\text { development }\end{array}$ & $\begin{array}{c}\text { Open-space conservation, } \\
\text { Massachusetts }\end{array}$ & Share $>65$ & Opposition & Collectivistic & Status quo & \\
\hline 48 & 17 & 2007 & Dehring et al. & Transportation & $\begin{array}{l}\text { Sales tax increase for mass } \\
\text { transit and street mainte- } \\
\text { nance, Arlington, May } 2002\end{array}$ & Share $>65$ & $\begin{array}{l}\text { Not signifi- } \\
\text { cant (in } \\
\text { two out of } \\
\text { three } \\
\text { models) }\end{array}$ & Neutral & Neutral & \multirow{3}{*}{$\begin{array}{l}\text { This is the same study as the } \\
\text { JUE publication, but the results } \\
\text { of the complementary analysis } \\
\text { of the transportation referenda } \\
\text { are reported only in the WP. }\end{array}$} \\
\hline 49 & 17 & 2007 & Dehring et al. & Transportation & $\begin{array}{l}\text { Sales tax increase for mass } \\
\text { transit and street mainte- } \\
\text { nance, Arlington, Feb. } 2003\end{array}$ & Share $>65$ & Opposition & Individualistic & Status quo & \\
\hline 50 & 17 & 2007 & Dehring et al. & Transportation & $\begin{array}{l}\text { Sales tax increase for mass } \\
\text { transit and street mainte- } \\
\text { nance, Arlington, Nov. } 2003\end{array}$ & Share $>65$ & $\begin{array}{c}\text { Not } \\
\text { significant }\end{array}$ & Neutral & Neutral & \\
\hline 53 & 18 & 2008 & $\begin{array}{l}\text { Lanz } \\
\text { Bornstein \& } \\
\quad \text { Lanz }\end{array}$ & Energy & $\begin{array}{c}\text { Switzerland, } 2000 \\
\text { Solar initiative, Switzerland, } \\
2000 \\
\end{array}$ & Share $>60$ & Opposition & Individualistic & Status quo & $\begin{array}{l}\text { This study analyzes the same } \\
\text { referenda as Thalmann (2004). } \\
\text { The solar initiative effect is not } \\
\text { significant in all models, but is } \\
\text { qualitatively consistent. }\end{array}$ \\
\hline 54 & 19 & 2008 & Dehring et al. & Sports facility & $\begin{array}{l}\text { Subsidized football stadium, } \\
\text { Arlington, Texas, } 2004\end{array}$ & Share $>65$ & $\begin{array}{c}\text { Not } \\
\text { significant }\end{array}$ & Neutral & Neutral & \\
\hline 55 & 20 & 2009 & Ahlfeldt et al. & Integration & EMU, Sweden 2004 & Average age & Opposition & Individualistic & Status quo & \\
\hline 56 & 20 & 2009 & Ahlfeldt et al. & Integration & $\begin{array}{c}\text { EU membership, Sweden, } \\
1994\end{array}$ & Average age & Opposition & Individualistic & Status quo & \\
\hline 57 & 20 & 2009 & Ahlfeldt et al. & Integration & EMU, Denmark, 2000 & Average age & Opposition & Individualistic & Status quo & \\
\hline 58 & 21 & 2010 & Banzhaf et al. & $\begin{array}{c}\text { Urban } \\
\text { development }\end{array}$ & $\begin{array}{l}\text { Land conservation referenda, } \\
\text { pooled, US, 1998-2006 }\end{array}$ & Share $>65$ & $\begin{array}{c}\text { Not } \\
\text { significant }\end{array}$ & Neutral & Neutral & \\
\hline
\end{tabular}




\begin{tabular}{|c|c|c|c|c|c|c|c|c|c|c|}
\hline \# & ID & Year & Author & Category & Referendum & Age variable ${ }^{a}$ & & Elderly Attitude & & Note \\
\hline 59 & 22 & 2010 & $\begin{array}{l}\text { Brunner \& } \\
\quad \text { Ross }\end{array}$ & $\begin{array}{l}\text { School } \\
\text { spending }\end{array}$ & $\begin{array}{l}\text { Lowering the required share } \\
\text { for passing educational bond } \\
\text { initiatives (propositions } 26 \\
\text { and 39), California, } 2000\end{array}$ & Share $>65$ & Opposition & Individualistic & Status quo & \\
\hline 60 & 23 & 2010 & $\begin{array}{l}\text { Hårsman \& } \\
\text { Quigley }\end{array}$ & Transportation & $\begin{array}{l}\text { Road toll to relieve conges- } \\
\text { tion, Stockholm, } 2006\end{array}$ & $\begin{array}{l}\text { Working-age popu- } \\
\text { lation as percentage } \\
\text { of total population }\end{array}$ & Opposition & Individualistic & Status quo & $\begin{array}{l}\text { The results imply that the el- } \\
\text { derly oppose the introduction } \\
\text { of a road toll, which was } \\
\text { proved to reduce congestion } \\
\text { during a trial period. }\end{array}$ \\
\hline 61 & 24 & 2011 & Wu \& Cutter & Transportation & $\begin{array}{c}\text { Passenger Rail and Clean Air } \\
\text { Bond Act (Proposition 156), } \\
\text { California, } 1992\end{array}$ & Share $>65$ & Support & Collectivistic & Change & \\
\hline 62 & 24 & 2011 & Wu \& Cutter & Transportation & $\begin{array}{l}\text { Passenger Rail and Clean Air } \\
\text { Bond Act (Proposition 181), } \\
\text { California, } 1998\end{array}$ & Share $>65$ & Opposition & Individualistic & Status quo & \\
\hline 63 & 24 & 2011 & Wu \& Cutter & Transportation & $\begin{array}{l}\text { Imposed tax on retail sales of } \\
\text { gasoline to fund investments } \\
\text { in transportation infrastruc- } \\
\text { ture (Proposition 185), Cali- } \\
\text { fornia, } 1994\end{array}$ & Share $>65$ & Opposition & Individualistic & Status quo & \\
\hline 64 & 24 & 2010 & Wu \& Cutter & Environment & $\begin{array}{l}\text { Bonds for water projects } \\
\text { (clean polluted water) (Prop- } \\
\text { osition 204), California, } 1996\end{array}$ & Share $>65$ & $\begin{array}{c}\text { Not } \\
\text { significant }\end{array}$ & Neutral & Neutral & $\begin{array}{c}\text { Block level SAR results are in- } \\
\text { terpreted (preferred by the } \\
\text { authors). }\end{array}$ \\
\hline 65 & 24 & 2010 & Wu \& Cutter & Environment & $\begin{array}{l}\text { Prohibition on trapping fur- } \\
\text { bearing mammals (Proposi- } \\
\text { tion 4), California } 1998\end{array}$ & Share $>65$ & Opposition & Individualistic & Status quo & \\
\hline 66 & 24 & 2010 & Wu \& Cutter & Energy & $\begin{array}{l}\text { Tax credits for emission re- } \\
\text { ductions (Proposition 7), Cali- } \\
\text { fornia, } 1998\end{array}$ & Share $>65$ & Opposition & Individualistic & Status quo & \\
\hline 67 & 24 & 2010 & Wu \& Cutter & Environment & $\begin{array}{c}\text { Bonds for water, forests, and } \\
\text { open space (Proposition 12), } \\
\text { California, } 2000\end{array}$ & Share $>65$ & Opposition & Individualistic & Status quo & \\
\hline
\end{tabular}




\begin{tabular}{|c|c|c|c|c|c|c|c|c|c|c|}
\hline$\#$ & ID & Year & Author & Category & Referendum & Age variable ${ }^{a}$ & \multicolumn{3}{|c|}{ Elderly Attitude } & Note \\
\hline 68 & 24 & 2010 & Wu \& Cutter & Infrastructure & $\begin{array}{c}\text { Bonds for Water Infrastruc- } \\
\text { ture (Proposition 13), Califor- } \\
\text { nia, } 2000\end{array}$ & Share $>65$ & Opposition & Individualistic & Status quo & \\
\hline 69 & 24 & 2010 & Wu \& Cutter & Infrastructure & $\begin{array}{l}\text { Bonds for county jails (Propo- } \\
\text { sition 205), California, } 1996\end{array}$ & Share $>65$ & Support & Collectivistic & Change & \\
\hline 70 & 24 & 2010 & Wu \& Cutter & $\begin{array}{l}\text { School } \\
\text { spending }\end{array}$ & $\begin{array}{l}\text { Bonds for education (Proposi- } \\
\text { tion 1A), California, } 1998\end{array}$ & Share $>65$ & Opposition & Individualistic & Status quo & \\
\hline 71 & 25 & 2011 & Ahlfeldt & $\begin{array}{c}\text { Urban } \\
\text { development }\end{array}$ & $\begin{array}{l}\text { Urban development project } \\
\text { "Mediaspree," Berlin, } 2008\end{array}$ & Share $18-45$ & Support & Collectivistic & Change & $\begin{array}{l}\text { 18-45-years olds opposed the } \\
\text { project (yes vote), implying } \\
\text { support by the elderly. }\end{array}$ \\
\hline 72 & 26 & 2011 & $\begin{array}{l}\text { Ahlfeldt \& } \\
\text { Maennig }\end{array}$ & Sports facility & $\begin{array}{c}\text { Allianz-Arena (soccer) and } \\
\text { subsidized infrastructure, } \\
\text { Munich, } 2001\end{array}$ & Share $>60$ & Support & Collectivistic & Change & $\begin{array}{l}\text { OLS result interpreted (pre- } \\
\text { ferred by the authors). The SAR } \\
\text { result is insignificant. }\end{array}$ \\
\hline 73 & 27 & 2012 & $\begin{array}{l}\text { Heintzelman } \\
\text { et al. }\end{array}$ & $\begin{array}{c}\text { Urban } \\
\text { development }\end{array}$ & $\begin{array}{c}\text { Introduction of urban growth } \\
\text { boundaries (Green Acres Pro- } \\
\text { gram), New Jersey, 1989- } \\
2009\end{array}$ & Share $>65$ & Support & Individualistic & Status quo & \\
\hline 74 & 28 & 2013 & Wagschal & Transportation & $\begin{array}{l}\text { State financing for Stuttgart } \\
21 \text { railway project }\end{array}$ & Average age & $\begin{array}{c}\text { Not } \\
\text { significant }\end{array}$ & Neutral & Neutral & $\begin{array}{l}\text { Analyzes the Stuttgart } 21 \text { ref- } \\
\text { erendum at the level of } 44 \\
\text { counties. }\end{array}$ \\
\hline 75 & 29 & 2014 & $\begin{array}{l}\text { Hersch \& } \\
\text { Pelkowski }\end{array}$ & $\begin{array}{l}\text { Health } \\
\text { services }\end{array}$ & $\begin{array}{c}\text { Fluoridation of public water, } \\
\text { Wichita, } 1978\end{array}$ & Share $>65$ & Opposition & Individualistic & Status quo & $\begin{array}{l}\text { Fluoridation is argued to have } \\
\text { positive effects for the dental }\end{array}$ \\
\hline 76 & 29 & 2014 & $\begin{array}{l}\text { Hersch \& } \\
\text { Pelkowski }\end{array}$ & $\begin{array}{l}\text { Health } \\
\text { services }\end{array}$ & $\begin{array}{c}\text { Fluoridation of public water, } \\
\text { Wichita, } 2012\end{array}$ & Share $>65$ & Opposition & Individualistic & Status quo & $\begin{array}{l}\text { health of children, but the el- } \\
\text { derly may regard themselves as }\end{array}$ \\
\hline 77 & 29 & 2014 & $\begin{array}{l}\text { Hersch \& } \\
\text { Pelkowski }\end{array}$ & $\begin{array}{l}\text { Health } \\
\text { services }\end{array}$ & $\begin{array}{c}\text { Fluoridation of public water, } \\
\text { Portland, } 2013\end{array}$ & Share $>65$ & $\begin{array}{c}\text { Not } \\
\text { significant }\end{array}$ & Neutral & Neutral & $\begin{array}{l}\text { more prone to alleged adverse } \\
\text { effects, such as kidney disease. }\end{array}$ \\
\hline 78 & 30 & 2015 & $\begin{array}{l}\text { Ahlfeldt \& } \\
\text { Maennig }\end{array}$ & Transportation & $\begin{array}{c}\text { New aviation concept, Berlin, } \\
2008\end{array}$ & Share $>55$ & Support & Collectivistic & Change & $\begin{array}{l}\text { The referendum challenged the } \\
\text { status quo (new aviation con- } \\
\text { cept). }\end{array}$ \\
\hline 79 & 31 & 2015 & $\begin{array}{l}\text { Coates \& } \\
\text { Wicker }\end{array}$ & Sports facility & $\begin{array}{l}\text { Winter Olympics 2022, Mu- } \\
\text { nich, } 2013\end{array}$ & Share $18-64$ & $\begin{array}{c}\text { Not } \\
\text { significant }\end{array}$ & Neutral & Neutral & \\
\hline
\end{tabular}




\begin{tabular}{|c|c|c|c|c|c|c|c|c|c|c|}
\hline$\#$ & ID & Year & Author & Category & Referendum & Age variable ${ }^{a}$ & & Elderly Attitude & & Note \\
\hline 80 & 32 & 2015 & Horn et al. & Sports facility & $\begin{array}{l}\text { Seahawk Stadium (subsi- } \\
\text { dized), Washington } 1997\end{array}$ & Share $>65$ & Support & Collectivistic & Change & \\
\hline 81 & 32 & 2015 & Horn et al. & $\begin{array}{l}\text { School } \\
\text { spending }\end{array}$ & $\begin{array}{l}\text { Extended period of voter- } \\
\text { approved school district lev- } \\
\text { ies (Resolution 4208), Wash- } \\
\text { ington, 1997 }\end{array}$ & Share $>65$ & Opposition & Individualistic & Status quo & \\
\hline 82 & 32 & 2015 & Horn et al. & Infrastructure & $\begin{array}{l}\text { Government loans for the } \\
\text { conservation of more effi- } \\
\text { cient use of storm water and } \\
\text { sewer services (Resolution } \\
\text { 4209), Washington, } 1997\end{array}$ & Share $>65$ & Opposition & Individualistic & Status quo & \\
\hline
\end{tabular}

Notes: a "Age" is the actual age of a voter reported in a post-election survey. "Average age" is the average age of the population within a geographic entity, typically a voting precinct. "Share $\lessgtr X$ " is the share of residents above or below a certain age within a geographic entity, typically a voting precinct. b Support/Not significant/Opposition indicate that the elderly effect on support in the referendum was significantly positive/not significant/significantly negative. Attitude is interpreted as individualistic if the effect on support is significant and in line with the definitions in Table 2 (unless otherwise indicated in the note), collectivistic if significant and pointing in the opposite direction, and neutral otherwise (insignificant effect on support). Attitude is status quo/neutral/change if the effect on support is significant and the direction implies that the status quo would be maintained/the effect on support is insignificant/the effect on support is significant and in a direction that implies a change of the status quo. 


\section{Bibliography}

Agostini, S. J., Quigley, J. M., and Smolensky, E. (1997). Stickball in San Francisco. In R. G. Noll and A. Zimbalist (Eds.), Sports, Jobs, and Taxes: The Economic Impact of Sports Teams and Stadiums (pp. 385-426). Washington, D.C.: Brookings Institution Press.

Ahlfeldt, G. M. (2011). Blessing or curse? Appreciation, amenities and resistance to urban renewal. Regional Science and Urban Economics, 41(1), 32-45.

Ahlfeldt, G. M., and Maennig, W. (2011). Voting on a NIMBY facility: Proximity cost of an "iconic" stadium. Urban Affairs Review, 48(2), 205-237.

Ahlfeldt, G. M., and Maennig, W. (2015). Homevoters vs. leasevoters: A spatial analysis of airport effects. Journal of Urban Economics, 87(0), 85-99.

Ahlfeldt, G. M., Maennig, W., and Osterheider, T. (2009). Regional and Sectoral Effects of a Common Monetary Policy: Evidence from Euro Referenda in Denmark and Sweden Hamburg Contemporary Economic Discussions, 28.

Balsdon, E., Brunner, E. J., and Rueben, K. (2003). Private demands for public capital: Evidence from school bond referenda. Journal of Urban Economics, 54(3), 610-638.

Banzhaf, H. S., Oates, W. E., and Sanchirico, J. N. (2010). Success and design of local referenda for land conservation. Journal of Policy Analysis and Management, 29(4), 769-798.

Bornstein, N., and Lanz, B. (2008). Voting on the environment: Price or ideology? Evidence from Swiss referendums. Ecological Economics, 67(3), 430-440.

Brunner, E., and Balsdon, E. (2004). Intergenerational conflict and the political economy of school spending. Journal of Urban Economics, 56(2), 369-388.

Brunner, E. J., and Ross, S. L. (2010). Is the median voter decisive? Evidence from referenda voting patterns. Journal of Public Economics, 94(11-12), 898-910.

Button, J. W. (1992). A sign of generational conflict: tThe impact of Florida's's aging voters on local school and tax referenda. Social Science Quarterly, 73(4), 786-797.

Coates, D., and Humphreys, B. R. (2006). Proximity benefits and voting on stadium and arena subsidies. Journal of Urban Economics, 59(2), 285-299.

Coates, D., and Wicker, P. (2015). Who voted against Munich's bid for the 2022 Winter Olympics? Working paper.

Dehring, C. A., Depken, C. A., and Ward, M. R. (2007). A direct test of the homevoter hypothesis. AIES/IASE Working Paper, 07-19.

Dehring, C. A., Depken, C. A., and Ward, M. R. (2008). A direct test of the homevoter hypothesis. Journal of Urban Economics, 64(1), 155-170.

Feigenbaum, S., Karoly, L., and Levy, D. (1988). When votes are words not deeds: Some evidence from the Nuclear Freeze Referendum. Public Choice, 58(3), 201-216.

Fischel, W. A. (1979). Determinants of voting on environmental quality: A study of a New Hampshire pulp mill referendum. Journal of Environmental Economics and Management, 6(2), 107-118.

Hårsman, B., and Quigley, J. M. (2010). Political and public acceptability of congestion pricing: Ideology and self-interest. Journal of Policy Analysis and Management, 29(4), 854-874.

Heintzelman, M. D., Walsh, P. J., and Grzeskowiak, D. J. (2012). A Multi-Method, Spatial Approach for Explaining the Appearance and Passage of Open Space Referenda. NCEE Working Paper, 12-02. 
Hersch, P. L., and Pelkowski, J. E. (2014). Voter demand for fluoridated water: A tale of two c(av)ities. Applied Economics Letters, 21(1), 51-54.

Hobolt, S. B. (2005). When Europe matters: The impact of political information on voting behaviour in EU referendums. Journal of Elections, Public Opinion and Parties, 15(1), 85109.

Horn, B. P., Cantor, M., and Fort, R. (2015). Proximity and voting for professional sporting stadiums: the pattern of support for the Seahawk stadium referendum. Contemporary Economic Policy, in press.

Kotchen, M. J., and Powers, S. M. (2006). Explaining the appearance and success of voter referenda for open-space conservation. Journal of Environmental Economics and Management, 52(1), 373-390.

Ladd, H. F., and Wilson, J. B. (1983). Who supports tax limitations: Evidence from Massachusetts' proposition 21/2. Journal of Policy Analysis and Management, 2(2), 256-279.

Noam, E. (1982). Demand functions and the valuation of public goods. Public Choice, 38(3), 271280.

Pelinka, A. (1983). The nuclear power referendum in Austria. Electoral Studies, 2(3), 253-261.

Rubinfeld, D. L. (1977). Voting in a local school election: A micro analysis. The Review of Economics and Statistics, 59(1), 30-42.

Rushton, M. (2005). Support for earmarked public spending on culture: Evidence from a referendum in metropolitan Detroit. Public Budgeting \& Finance, 25(4), 72-85.

Schulze, G. G., and Ursprung, H. W. (2000). La donna e mobile -- or is she? Voter preferences and public support for the performing arts. Public Choice, 102(1/2), 131-149.

Thalmann, P. (2004). The public acceptance of green taxes: 2 million voters express their opinion. Public Choice, 119(1-2), 179-217.

Wagschal, U. (2013). Die Volksabstimmung zu Stuttgart 21 - ein direktdemokratisches Lehrstück? In U. Wagschal, U. Eith and M. Wehner (Eds.), Der historische Machtwechsel: Grün-rot in Baden-Würtemberg (pp. 181-205). Berlin: Nomos.

$\mathrm{Wu}, \mathrm{X}$., and Cutter, B. (2011). Who votes for public environmental goods in California?: Evidence from a spatial analysis of voting for environmental ballot measures. Ecological Economics, $70(3), 554-563$. 